\title{
Ka Mua, Ka Muri-Walking Backwards into the Future: An Environmental History of the South Wairarapa Region 1984- 2016
}

By

Eleanor Jane Rainford

A thesis submitted to Victoria University of Wellington in fulfilment of the requirements for the degree of Master of Arts in History

Victoria University of Wellington 


\begin{abstract}
'Ka mua, ka muri', Walking backwards into the future, is a Māori proverb that aptly describes the findings of this thesis. That we should look to the past to inform the future is arguably the purpose of history, yet we have to walk back far enough. Tracing back from the present, this thesis will address what has driven political, economic, environmental and social change within the South Wairarapa region from 1984 to the present day. The region has experienced significant changes to its physical and social environment over the past thirty years. Many modern historians have attributed the key changes of this period, such as agricultural intensification, diversification, rising unemployment and environmental degradation, to the economic re-structuring of the Fourth Labour Government. This thesis will argue that these changes, and neoliberal reform itself, are consequent of much longer historiographical trends. Examination of the historical context and legacies of the intensification of dairy farming, rise of the viticulture industry, and the relationship between Ngāti Kahungunu and Rangitāne o Wairarapa and their whenua, reveals complexities in the history of the region that histories of neoliberal change commonly conceal. The identification of these long running historiographical trends aides understanding of the historical context in which neoliberal reform occurred, and provides alternative narratives for the changes that have occurred over the past thirty years. Furthermore, it suggests alternative trajectories for how viticulture, agriculture and Te Ao Māori may walk into the future.
\end{abstract}




\section{Table of Contents}

Acknowledgements. 6

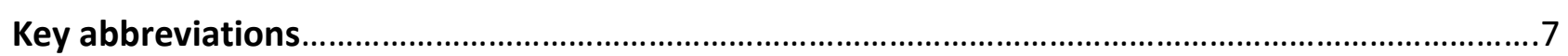

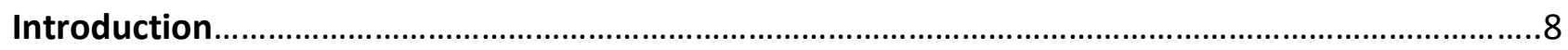

Fig.1: Map showing South Wairarapa District boundary as of the

1989 Local Government Reforms Act.

Chapter 1: Agriculture. Off the sheep's back. 17

Fig.1: Table showing sheep and cattle numbers 1984-2010...... .20

Fig.2: Graph showing relative NZ farm income 1970-1984. 22

Fig.3: Table showing South Wairarapa farm holdings and stock numbers 1990-1996. 26

Fig.4: Graph showing Wairarapa agricultural areas in hectares $1984 .$. .27

Fig.5: Graph showing Wairarapa agricultural areas in hectares 2017. .27

Fig.6: Graph showing farm types in the South Wairarapa District

by industry classification as at June 2012 . .30

Chapter 2: Viticulture. 'Farming was shot, we had to diversify' 45

Fig 1: Comparative table of Burgundian, Wairau and Martinborough terroir..... .52

Fig 2: Graph showing Wairarapa principal grape varieties 2008. .53

Fig 3: Table showing Air New Zealand Wine Awards

medal wins for pioneer Martinborough wineries 1986-1989... .55

Fig 4: Map showing vineyard placement and appellation areas..... .59

Fig 5: Table showing wine companies by size as at June 2016. 62

Fig.6: Table showing share of wine exports by company size...... .63

Fig.7: Graph showing average spend by international tourist (2015 Sept Year)....... .65 
Chapter 3: Ngāti Kahungunu ki Wairarapa and Rangitāne o Wairarapa

'You can't get kai from the river any more' ..........................................................................................

Fig.1: Map showing traditional occupation of the Inquiry District $1800-1840$ s..................................77

Fig.2: Map showing Ōnoke spit and Wairarapa Moana as at 1855....................................................79

Fig.3: Photograph showing Māori group on the Ruamāhanga River 1870s-1880s..............................81

Fig.4: Newspaper clipping, 'Iwi struggle to protect history' ...............................................................83

Fig.5: Flow diagram showing the progression of the Wairarapa Moana Claims Process....................96

Fig.6: Map showing Ngāti Kahungunu marae sites for whole of New Zealand.................................100

Fig.7: Map showing Rangitāne marae sites for whole of New Zealand............................................100

Fig.8: Graph showing Māori unemployment rate (NZ) 1986-2014...................................................101

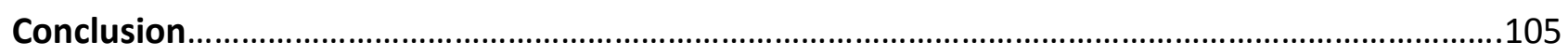

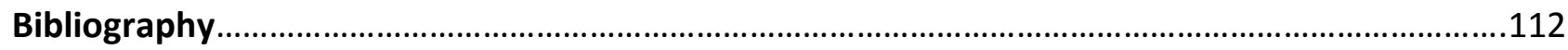




\section{Acknowledgements}

My foremost thanks is to those who encouraged me to embark into the world of New Zealand, and environmental history in the first place. To my supervisor Jim McAloon, your encouragement, insight and patience inspired me, motivated me and kept me on track. Thank you for persuading me to read some economic history that wasn't Das Kapital- you were right, it was necessary. To Brenda and Aporo Joyce, donors of the Jack Pearce Scholarship, thank you for your initial encouragement and continued support, this thesis would not have happened without it. To all the History Faculty staff, thank you for your guidance through undergrad and honours and your offers of expertise and kind words of encouragement this past year.

It seems a long time since this project began, and I am incredibly thankful to my peers, friends and family, both inside and outside the University walls for keeping me sane, offering a helping hand and being by my side when the year got tough. In particular, thank you to Carine Stewart for all the fist bumps of encouragement and for teaching me that full stops only go on the end of sentences. I am so grateful to the people I have met, and learnt from along the way; Paora Ammunson, Alan Wilde, Peter Howland, Gareth Winter and again, Jim McAloon, this thesis is a collection of your stories, your work, and your inspiration, it could not, and would not exist without you. Finally, thank you to my un-official publicist: Ann Rainford, your constant enthusiasm and pride makes me strive to be everything you think I can be. 


\section{Key Abbreviations}

A.R.G.O.S- Agricultural Research Group on Sustainability.

D.O.C- Department of Conservation.

D.S.I.R- Department of Scientific and Industrial Research.

E.E.C- European Economic Community.

G.W.R.C- Greater Wellington Regional Council.

L.G.A- Local Government Act.

M.L.C- Māori Land Court.

M.W.A- Martinborough Winemakers Association.

N.I.W.A- National Institute of Water and Atmosphere.

R.M.A-Resource Management Act.

R.N.Z- Radio New Zealand.

S.M.P-Supplementary Minimum Prices

S.W.D.C- South Wairarapa District Council.

S.W.N.Z- Sustainable Winegrowing New Zealand. 


\section{$\underline{\text { Introduction }}$}

'Ka mua, ka muri' translates from Te Reo to English as 'Walking backwards into the future'. This proverb informs this thesis, which will reconsider the narrative framework within which contemporary history views the neoliberal reforms of the 1980 s and their social, cultural, economic and environmental ramifications. As a geographically defined region that has undergone a significant number of physical, economic and social changes, South Wairarapa presented an attractive case-study for achieving this. This thesis contextualises the neoliberal reforms of 1984 within a wider historiographical trajectory, using this contextualisation to examine the economic, social and physical changes of the past thirty years with regard to three key areas of change: agriculture, viticulture and the position of Tangata Whenua within their ancestral lands.

Fig. $1^{1}$

\section{South Wairarapa District boundary as of the 1989 Local Government Reforms Act}

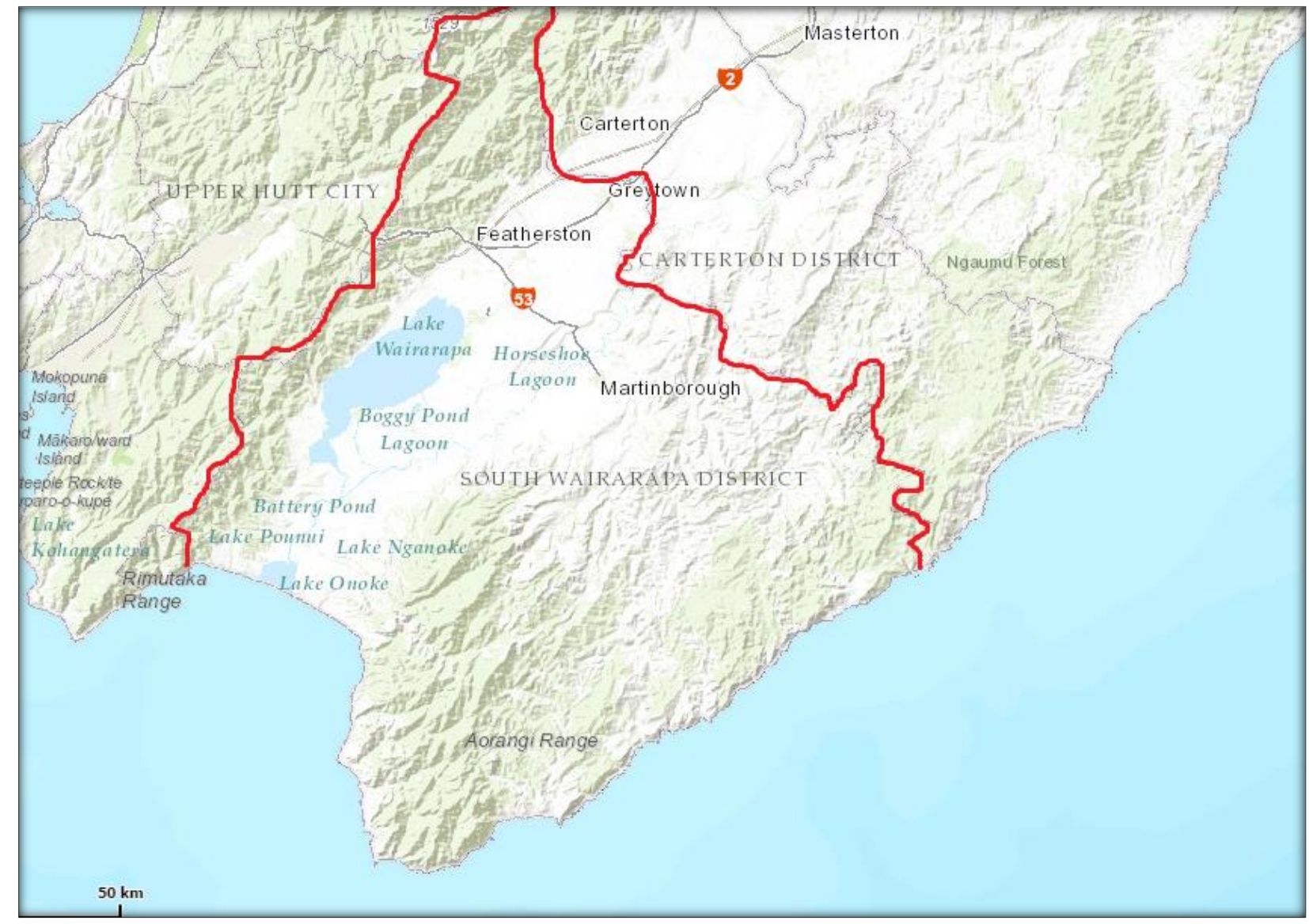

\footnotetext{
${ }^{1}$ South Wairarapa District Council, 'Wairarapa Maps', District Plan. http://mapping.gw.govt.nz/Wairarapa/. (accessed
} 04/05/2017). 
The South Wairarapa encompasses the southern-most point of the East Coast of the North Island of New Zealand, from the foothills of the Rimutakas in the north-west to Cape Palliser and the Canoes of Kupe in the south-east. It is a geographically diverse region comprising hill country, fertile plains, alluvial rises, riverbeds, wetlands and a coastline exposed to the Pacific Ocean. Two lakes lie in the south-west of the region, the larger Wairarapa Moana and the smaller, Lake Ōnoke, which is separated from the coast by a natural sandbar known as Ōnoke Spit, and is met by the Ruamāhanga River which snakes its way through the region. In 2017 the South Wairarapa is home to successful viticulture, agriculture and tourism industries; its three major townships; Greytown, Featherston and Martinborough, are characterised by eateries, boutiques and quaint bed and breakfasts.

Archaeological evidence suggests that Māori have inhabited the region for at least 850 years. Oral history and tradition have carried myths and legends of origin. ${ }^{2}$ The historical trajectory of preEuropean Māori links Rangitāne o Wairarapa Māori and Ngāti Kahungunu Māori to the region in a physical capacity, as well as a cultural and spiritual one.

The tuaone (foreshore, beach) and tahuaroa (ocean) were important sources of mahinga kai and a fundamental part of māoritanga. ${ }^{3}$ During the summer months, men carried out deep sea fishing, bringing in catches of fresh fish and seabirds. ${ }^{4}$ In the winter months many settlers moved inland to escape the harsh coastal conditions. The cultural and spiritual significance of the coastline for Tangata Whenua encompassed all aspects of it: the seabed, foreshore, sea itself, and air around it.

The whakapapa of Kahungunu and Rangitāne links Wairarapa Moana and the surrounding rohe to the legend of Maui. Former Ngāti Kahungunu chairperson Paora Ammunson noted that in the twenty-first century local Māori continue to refer to the lakes as Te Ika a Maui, or 'the eye of Maui's fish', for identity purposes. ${ }^{5}$ Ōnoke Spit was of great cultural significance to Tangata Whenua. The sand bar was the embodiment of Taniwha Rakairuru, guardian of the Wairarapa Moana, who would close the mouth of the lake each autumn prior to the annual eel migration. ${ }^{6}$ Floods coinciding with Rakairuru's closing of the lake mouth swelled the lakes by a further thousand square acres, flooding

\footnotetext{
${ }^{2}$ A. G. Bagnall, Wairarapa; an historical excursion, Hedleys Bookshop LTD for The Masterton Trust Lands Trust, Masterton, 1976. p.1.

${ }^{3}$ Definitions for all Māori words used in this thesis are taken from Te Whanake; Māori Dictionary online. http://maoridictionary.co.nz/.

${ }^{4}$ The Wairarapa Ki Tararua Report; Volume I The people and the Land, Waitangi Tribunal Report 2010, WAI 863. p.6.

${ }^{5}$ Eleanor Rainford, Interview with Paora Ammunson, Greytown Library, 31/11/2016, File 0135, Tascam DR60D.

${ }^{6}$ Caleb Royal, Cultural Values for Wairarapa Waterways, Ohau Plants LTD \& Greater Wellington Regional Council, November 2011. p.22. http://www.gw.govt.nz/assets/Our-Environment/Environmental-monitoring/Cultural-Valuesfor-Wairarapa-Waterways-report.pdf. (accessed 13/12/2016).
} 
the surrounding land. ${ }^{7}$ This seasonal flooding was an integral part of the South Wairarapa ecosystem and traditional culture. The fertile floodplains were the natural habitat of many culturally significant species of flora and fauna. ${ }^{8}$ Eels in particular were a very important source of food and held a special place in Māori mythology as an ancient gift from the gods. ${ }^{9}$

The Ruamāhanga River is strongly linked to Tangata Whenua through whakapapa to ancient ancestors. The river takes its name from an ancestor from the Kurahaupo waka, Haunuiananaia, who travelled the lower half of the North Island looking for his wife and naming many awa and maunga along the way. He named the river for two birds that he saw ensnared in the fork of a tree as he traversed the waters: rua- meaning two, referring to the two birds, and māhanga- meaning twin, the fork in the tree. ${ }^{10}$ As the 'blood veins of Papatūānuku', the significance of rivers extends much further within the Māori worldview than the Western one. ${ }^{11}$ The Ruamāhanga and its tributaries are of immense cultural significance to Māori: they are a fundamental part of their understanding and management of interconnected resources and ecosystems known as ki uta ki tai. $^{12}$

Permanent European settlement of the region began in the 1840s when a group of five men inquired about the acquisition of land in the Wairarapa. The journey of Charles Clifford Bidwill and his flock of 350 merinos from Wellington to the Wairarapa is the makings of a modern day legend of pastoral farming. ${ }^{13}$ Initially sheep runners leased land from local Māori, an agreement that lasted for about twelve years until the Crown intervened in $1853 .{ }^{14}$ Governor George Grey and Crown purchase agent Donald Mclean convinced local Māori to sell their land to the Crown by outlawing direct leasing by Māori to settlers with the Land Ordinance of $1853 .{ }^{15}$ By 1880 the Wairarapa had 325 European settlements. ${ }^{16}$ In the decades that followed, South Wairarapa's ecosystem was

\footnotetext{
${ }^{7}$ The Wairarapa Ki Tararua Report; Volume I. p.2.

${ }^{8}$ Margaret Forster, 'Recovering our ancestral landscapes: A wetlands story' in Māori and the Environment: Kaitiaki, Huia Publishers, Wellington, 2010. p.200.

9 Joseph Potangaroa, Tuna Kuwharuwharu; The Longfin Eel: An educational resource, Facts, threats and how to help, Rangitāne o Wairarapa Inc, Greater Wellington Regional Council, Department of Conservation, 2010. p.5

${ }^{10}$ Caleb Royal, Cultural Values for Wairarapa Waterways. p.13.

${ }^{11}$ The Wairarapa Ki Tararua Report; Volume III Powerlessness and Displacement, Waitangi Tribunal Report 2010, WAI863. p.849.

12 Tom Brooking and Eric Pawson, Making a new land: environmental histories of New Zealand, University Otago Press, Dunedin, New Zealand, 2013. p.182.

${ }^{13}$ Bagnall, Wairarapa; an historical excursion. p.52.

${ }^{14}$ Judge C.M Wainwright (presiding officer), 'Letter to honourable Pita Sharples, Minister of Māori Affairs, 26/06/2010', The Wairarapa Ki Tararua Report; Volume I. p.Lii.

${ }^{15}$ The Wairarapa Ki Tararua Report; Volume I. p. 24.

${ }^{16}$ Bagnall, Wairarapa; an historical excursion. p.321.
} 
transformed from a hunter-gatherer based one to a new intensive pasture based ecosystem. By 1990 only ten percent of land remained in the hands of Māori. ${ }^{17}$

Eric Pawson and Tom Brooking have argued that 'the environments that we inhabit are inseparable from human culture'. ${ }^{18}$ The situation in the South Wairarapa from the late nineteenth century to the twentieth century is a prime example of this. While seasonal flooding and the natural resources of the Wairarapa Moana wetlands were of economic, cultural and spiritual significance to Māori, for pastoral farmers they were a nuisance.

Beginning in 1876 a number of parliamentary acts lay the groundwork for the drainage of the Wairarapa Moana wetlands, facilitating large scale conversion of the land to pasture and safeguarding pre-existing farms from flooding. ${ }^{19}$ The South Wairarapa River Board declared Lake Ōnoke to be 'a public drain', enabling Ōnoke Spit to be artificially opened when farms were threatened. In June 1888 despite considerable contestation from Tangata Whenua, the lake was artificially opened for the first time. ${ }^{20}$ This continued throughout the twentieth century. In 1947 a severe flood provoked further action by the River Board. The Ruamāhanga River, which had initially flowed into Wairarapa Moana was diverted, so that it now flowed into Lake Ōnoke. ${ }^{21}$ The lake mouth could now be opened and closed to prevent flooding, not only from the lake, but from the Ruamāhanga River too. By the early twentieth century the South Wairarapa had transformed from a region of migratory tribes to a network of rural communities, supported by the small service towns of Greytown, Featherston and Martinborough. ${ }^{22}$

The South Wairarapa as we find it today is a by-product of the profound physical, economic and cultural changes undergone in the colonisation of New Zealand. Yet the period from the 1960s up until the present day introduced a new development in human culture to which both Tangata Whenua and settler society were subject. As the world-economy changed and the post war settlement began to rupture New Zealand's pastoral export driven economy faced a number of significant obstacles. ${ }^{23}$ The poor performance of wool and meat exports on international markets threatened the stability of the settler built staples economy, creating a need for product

\footnotetext{
${ }^{17}$ The Wairarapa Ki Tararua Report; Volume II The struggle for control. p.601.

${ }^{18}$ Brooking and Pawson, Making a new land. p.19.

19 ibid. pp.181-187.

${ }^{20}$ The Wairarapa Ki Tararua Report; Volume II The struggle for control. p.659.

${ }^{21}$ Ben Schrader, 'Wairarapa places - Wairarapa lakes', Te Ara - the Encyclopedia of New Zealand. http://www.TeAra.govt.nz/en/wairarapa-places/page-11. (accessed 02/05/2017).

${ }^{22}$ Roberta McIntyre, Canoes of Kupe: a History of the Martinborough District, Fraser Books, Masterton, 2012. p.252.

${ }^{23} \mathrm{Jim}$ McAloon, Judgements of all kinds; Economic Policy Making in New Zealand 1945-1984, Victoria University Press, Wellington, 2013. p.126.
} 
diversification. ${ }^{24}$ This in turn meant environmental change. An emphasis on continuing high production, spurred on by generous farming subsidies from the 1960s up until 1984, substantially increased the area farmed in the region. Farmers were encouraged to increase their stocking rates, develop marginal land for agriculture and diversify production. ${ }^{25}$ It was becoming clear that successive government attempts at managing the balance of payments through state sponsored pastoral farming were failing. In 1980 Treasury suggested that all state support for primary industry be removed, exposing the export sector to the market realities that New Zealand Governments had been protecting them from for the past forty years. In 1984 the newly elected Fourth Labour Government under David Lange and Finance Minister Roger Douglas took Treasury's advice, deregulating the economy and removing all subsidies for primary industry.

Much scholarly attention has been paid to the neoliberal reforms of the Fourth Labour Government and their ongoing legacy. As Tom Brooking and Eric Pawson observe, 'history reflects the anxieties of its times'; ${ }^{26}$ yet, observation of the South Wairarapa suggests that the fundamental drivers of change lie outside of the immediacy of these reforms. Both change and the reforms themselves were a result of broader ecological revolutions pertaining to land use, cultural change and resource distribution.

Many scholars emphasise the changes that took place in the years 1984-2016 or speak of the reforms as if they were a sudden revolution sprung on an unsuspecting society. If the reforms are placed in historical context, two trends become apparent. The shorter trend pertains to the fact that New Zealand had been attempting to function on deregulated international markets, while heavily regulating its domestic economy for much of the twentieth century. As Jim McAloon contended, New Zealand governments had been 'negotiating the terms on which New Zealand, a small settler economy, would engage with the rest of the world' since $1935 .{ }^{27}$ Similarly, C.B. Schedvin argued in 1990 that the dependence of New Zealand's economy upon agriculture and a limited scope for diversification in to other industries and commodities had led to a policy of agricultural protectionism that ignored international market realities from the interwar period on. ${ }^{28}$ The 1984

\footnotetext{
${ }^{24}$ C.B. Shevdin, 'Staples and regions of Pax Britannica', The Economic History Review, Vol. 42, No.4, November 1990. p.546.

${ }^{25}$ Neal Wallace, When the Farm Gates Opened; The impact of Rogernomics on rural New Zealand, Rachel Scott, Wellington, 2014. p.34.

${ }^{26}$ Brooking and Pawson, Making a new land. p.18.

${ }^{27}$ McAloon, Judgements of all kinds. p.218.

28 Shevdin, 'Staples and regions of Pax Britannica'. p.545.
} 
reforms were so notable because they signalled an opening of the New Zealand economy to these external realities.

The longer trend draws parallels with the work of geographer David Harvey and his theory of ecological revolutions. Harvey stated that 'all proposals concerning the environment are necessarily and simultaneously proposals for social change, and that action on them always entails the instantiation in "nature" of a certain regime of values. ${ }^{29}$ Social and cultural change leads to a change in resource use or requirements. In the case of the South Wairarapa, the emphasis placed by Tangata Whenua on the natural resources of the wetlands was displaced by settler emphasis on dry land for pastoral farming, which was in turn displaced by capitalism's emphasis on intensification and diversification. At each step, this change in cultural emphasis led to a change in resource use, which resulted in different environmental implications. To this end we may see neoliberal capitalism as another cultural stage in an ecological revolution. The question remains however, what will replace it?

While Harvey's work is useful in consideration of environmental and ecological change, the work of Pierre Bourdieu is particularly useful in social and economic considerations. In order to facilitate cultural change there must be a displacement of the pre-existing culturally dominant group. Bourdieu's work offers an explanation as to how and why cultural change occurs in the first place. Agents and groups are distributed in social space according to their relative positions of economic, political, social and cultural capital. ${ }^{30}$ Economic capital refers to the respective income or wealth of a group or individual; social, cultural and political capital are more subjective. Each of the latter is based upon relations with other individuals and groups; while social and cultural capital may be used as synonyms for mana, prestige or respect, political capital refers to the relation of groups or individuals to the politics of the day. ${ }^{31}$ Although social and cultural capital are significant in terms of day to day relations, political capital and economic capital are the primordial drivers of change, enabling their holders to form private appropriations of resources, goods and services. ${ }^{32}$ This is particularly pertinent to the South Wairarapa example when we investigate the yo-yoing relations between government and farmers.

Bourdieu's concept of social space is also useful when examining the subjectivities of farmers. The concept of habitus does not function as a simple variable but is valuable in considerations of why

\footnotetext{
${ }^{29}$ David Harvey, Justice, Nature and the Geography of Difference, Blackwell Publishers, Oxford, 1996. p.129.

${ }^{30}$ Pierre Bourdieu, Practical Reason; On the Theory of Action, Stanford University Press, Stanford, California, 1998. p.6

${ }^{31}$ ibid. p.16.

${ }^{32}$ ibid.
} 
farmers with even distributions of capital behave in different ways. It also accounts for the development of the 'Martinborough wine connoisseur', identified by Peter Howland in his work on Wairarapa wine. ${ }^{33}$ Habitus is a product of social conditioning through which people form subjective relations with goods, properties and ideas. Although individuals within groups are often unified by their habitus, it is a distinctly individual set of relations and practices. ${ }^{34}$ Habitus has enabled rural sociologists to account for why two farmers in similar socio-economic situations may make fundamentally different decisions with regard to their farming practices. ${ }^{35}$ On the other hand, it is an appeal to a certain habitus that accounts for the rise in wine tourism and subsequent boutique accommodation, clothing shops, cafes and galleries, particularly in Martinborough. ${ }^{36}$

Within the South Wairarapa residents hold diverse and complex economic, social and environmental values. As Harvey states 'social objectives and goals can vary greatly depending on who is doing the desiring about what, and how, human desires get institutionalised, discursively expressed and politically organised. ${ }^{37}$ There has been very little historical scholarship examining rural change over the past thirty years, and less still with a focus on the South Wairarapa and environmental factors. Where historical scholarship has been consulted, it is in the context of broader themes of environmental history in the works of Eric Pawson, Tom Brooking, Catherine Knight and William Cronon. Otherwise historiographical scholarship has provided a primarily contextual basis for the work. The one exception to this is the Wairarapa ki Tararua Report which has provided an environmental and contextual framework, and primary evidence, particularly for chapter three. ${ }^{38}$ The proceedings of the Waitangi Tribunal have been an invaluable source of information, particularly as the hearings and settlement of the claims took place within the timeframe under consideration.

It was the original intention of this thesis to gather anecdotal evidence of the changes in South Wairarapa through a series of semi-structured oral history interviews. However, I found that

\footnotetext{
33 Peter Howland, 'Martinborough's Wine Tourists and the Metro-Rural Idyll', Journal of New Zealand Studies, Issue 6, 2008. p.82.

${ }^{34}$ Bourdieu, Practical Reason. p.7.

${ }^{35}$ Lesley M. Hunt, John. R. Fairweather, Chris. J. Rosin, Hugh Campbell, Dave Lucock \& Gen Greer, 'Doing the Unthinkable: Linking farmers' breadth of view and adaptive propensity to achievement of social, environmental and economic outcomes', 18th International Farm Management Congress Methven, Canterbury Conference proceedings, New Zealand, 2011. p.201.

${ }^{36}$ Howland, 'Martinborough's Wine Tourists and the Metro-Rural Idyll'. p.82.

${ }^{37}$ Harvey, Justice, Nature and the Geography of Difference. p.147.

${ }^{38}$ The Wairarapa Ki Tararua Report; Volume I.

The Wairarapa Ki Tararua Report; Volume II.

\& The Wairarapa Ki Tararua Report; Volume III.
} 
evidence of subjectivities was readily available through a number of different resources including print media, government and non-government conducted surveys and the work of previous historians. Heather Cormack's 1990 Martinborough Winemakers Oral History Project provided an important insight into the origins of the viticulture industry in the region, and insights into some of the early challenges that pioneering viticulturists faced. This enabled me to focus on the ecological and economic impacts of the reforms, sources for which were difficult to gather due to the change in local government structure in 1989.

In addition to the primary source material gathered I conducted two interviews. An email interview with freshwater ecologist Dr Russell Death was conducted in order to ascertain a succinct overview of what he believed to be the consequences of intensified dairy farming. Although Death has been interviewed many times through media channels, I deemed it necessary to be able to frame his responses within a more specific context.

I also interviewed former Ngāti Kahungunu Chairperson and District Councillor Paora Ammunson. The interview was semi-structured and qualitative in format, allowing me to shape the interview but also to gather anecdotal and contextual evidence and information. Paora Ammunson was an important individual to interview in person: he was involved in the early days of the Wairarapa Moana project, was the Chairperson of Ngāti Kahungunu during the conception of the project, is the guardian of Papawai Marae in Greytown, and is heavily involved in local and Māori politics through his work in the community and as a District Councillor. The interview provided subsidiary context and anecdotal evidence of local subjectivities to chapter three.

This thesis will begin by examining changes to the South Wairarapa agricultural community. Many scholars have suggested that it was farmers who were hit hardest by Roger Douglas's reforming budget of 1984. This chapter will examine the effects of the deregulation of the agriculture industry on South Wairarapa farmers within the historical context of the years that preceded and followed the reforms. The chapter's three sections address the diversification of agriculture, the social effects of the removal of subsidies both on the community and on farming subjectivities, and the ways in which the farming community has responded to international market pressures and concerns over the agriculture industry's environmental footprint.

Chapter two examines the rise of the South Wairarapa viticulture industry, beginning with the origins of the industry in the late 1970s. The first section addresses the incentives that the eight pioneering Martinborough winemakers had for introducing viticulture to the region and the challenges they faced. The second section addresses the development of the region into a boutique 
wine growing area and the market incentives and business decisions that drove this characterisation. The final section addresses the social, economic and environmental changes facilitated by the rise in the South Wairarapa viticulture industry.

Finally, chapter three re-examines and contextualises the social space that Ngāti Kahungunu and Rangitāne o Wairarapa Māori have occupied in the South Wairarapa over the past thirty years. This chapter addresses the historical and contemporary grievances of the region's Māori and how these are being addressed by governance structures, Tangata Whenua and the greater South Wairarapa public. On a subjective level this chapter outlines the ongoing cultural discord between the values of Tangata Whenua and governance structures, especially with regard to water and natural resources. Ultimately key areas of success and failure with regard to the acknowledgement of Māori cultural values in regional policy making are addressed.

Drawing together the historical trajectories of these three distinct and interwoven groups in South Wairarapa society allows a broad lens in which to examine the social, economic and cultural implications of neoliberal reform in the region. Examining their histories individually emphasises the necessity of contextualising change in order to identify the complexities that both drive, and result from, change in societal groups. It is evident that neoliberal reform has been one of a number of instigators of change in the region over the past thirty years, and arguably not the most prominent one. 


\section{Chapter 1: Agriculture}

\section{Off the sheep's back}

The restructuring of economic policy that followed the 1984 election is often described as the catalyst for radical departures in New Zealand farming practice. Colin James wrote in 1986 that farmers had been affected worst by the neoliberal reforms of the Fourth Labour Government. ${ }^{1}$ This chapter will argue that within the context of the South Wairarapa, farmers had experienced changes to farming practices long prior to 1984 . For more than a century after 1850 , the emphasis in New Zealand farming was on the intensification of production; however restructuring of the external economic environment after World War II exposed the vulnerability of New Zealand's agricultural exports to international political and economic changes. From the 1950s successive New Zealand governments shielded the pastoral industry from fluctuating export prices through protectionist measures; however, the country's economic situation did not improve and produce prices failed to stabilise. After many years of economic protectionism, the reforms of the Fourth Labour Government fully exposed the sector to market realities, removing incentives for intensification and ending supplementary prices.

The bulk purchase of agricultural commodities by Britain between 1940 and 1954 provided impetus for maximum agricultural productivity. The resulting trend, defined by rural sociologists as agricultural productivism, referred to the activity of achieving the largest output of produce possible from the smallest plots of land and number of stock. From the 1950s New Zealand's pastoral export economy faced a number of obstacles. From 1954 British demand for dairy, wool and meat products began to decrease, forcing a broadening of the export market to Asia, Australia and the United States. ${ }^{2}$ There was also a push to diversify the types of agricultural products available after the 1966 wool crash, which resulted in a balance of payments crisis. ${ }^{3}$ Despite poor returns for pastoral commodities on overseas markets, agricultural productivism continued to dominate policy. In March 1968, Prime Minister Keith Holyoake convened a National Development Conference where it was decided that although price expectations for traditional products were poor, it was necessary to continue to rely on them in the medium term while alternatives were developed. ${ }^{4}$

\footnotetext{
${ }^{1}$ Colin James, The Quiet Revolution; Turbulence and Transition in Contemporary New Zealand, Allen and Unwin, Wellington, 1986. p.182.

2 Daniel Conforte, Elena Garnevska, Mark Kilgour, Stuart Locke and Frank Scrimgeour, The Key Elements of success and failure in the NZ Dairy Industry, Research Report No.313, Lincoln University, Christchurch, December 2008 . p.4.

${ }^{3}$ McAloon, Judgements of all kinds. p.126

4 McAloon, Judgements of all kinds. p.140.
} 
From 1969 the New Zealand Government began to incentivise farmers through a number of economic concessions. Subsidisation began with generous tax allowances for the conversion of farms from sheep to beef and dairy. The 1970 budget extended support to farmers with the development of fertiliser subsidies and the exemption of farmland from tax. ${ }^{5}$ In 1973 Britain joined the European Economic Community (EEC); although James Belich and others have argued that this marked 'the turning point of decolonisation', New Zealand had been widening its trade community since the mid-1950s. ${ }^{6}$ The first Oil Shock of 1973 further affected the global economy and the economic viability of running a farm. ${ }^{7}$

In 1976 Finance Minister Robert Muldoon and Treasury agreed that despite the poor performance of agricultural goods on the international market, continuing farm support was justified for the foreseeable future. ${ }^{8}$ The Livestock Incentive Scheme (1976) encouraged farmers to increase their stocking rates, particularly those of sheep, while the Land Development Encouragement Loan Scheme (1976) provided funds for start-up farmers to begin production on marginal land. ${ }^{9}$ Supplementary Minimum Prices (SMP), introduced in 1978, were the largest financial supplement to the agriculture industry, primarily subsidising fertilizer prices and sheep meat. ${ }^{10}$ However, after the second Oil Shock in 1978-79 Treasury warned that the economy was still fragile and that another balance of payments crisis was likely. ${ }^{11}$ The protectionist model of capitalism was costing New Zealand more than the agriculture industry was making, with many farmers reliant upon subsidies for their household as well as farming incomes. ${ }^{12}$ From 1980 onward Treasury firmly advocated deregulation. ${ }^{13}$

The Fourth Labour Government, elected in 1984, was to rapidly and radically restructure the New Zealand economy. Their reforms sought to expose the economy to the market forces that governments had vigorously protected it from since the 1930 s. ${ }^{14}$ As the most heavily subsidised

\footnotetext{
${ }^{5}$ ibid. pp.140-141.

${ }^{6}$ James Belich, Paradise Reforged; A History of New Zealanders from the 1880s to year 2000 in Jim McAloon, Judgements of all kinds; Economic Policy Making in New Zealand 1945-1984, Victoria University Press, Wellington, 2013. p.142.

${ }^{7}$ Belich, Paradise Reforged. p.396.

${ }^{8}$ McAloon, Judgements of all kinds. p.161.

${ }^{9}$ Wallace, When the Farm Gates Opened. p.34.

${ }^{10}$ Willie Smith and Hayden Montgomery, 'Revolution or Evolution? New Zealand agriculture since 1984', GeoJournal, Vol.59, No.2, Re-Inventing Government: Emerging Geographies in New Zealand, 2004. p.107.

${ }^{11}$ McAloon, Judgements of all kinds. p.176.

12 Wallace, When the Farm Gates Opened. p.12.

${ }^{13}$ McAloon, Judgements of all kinds. p.187.

${ }^{14}$ Richard Le Heron and Eric Pawson, Changing Places; New Zealand in the Nineties, Longman Paul, Auckland 1996. p.15.
} 
industry, agriculture became the primary target of de-regulation. The de-regulation of the New Zealand economy and the painting of pastoral agriculture as a 'sunset industry' by Roger Douglas' reforming first budget, is claimed by many to have had profound consequences throughout New Zealand farming communities. ${ }^{15}$

Colin James, a journalist, and Lewis Evans, an economist, argued that the economic liberalisation of the 1980s and the withdrawal of Government support from primary industries was symptomatic of revolution but not its cause, a reaction to forty years of inward looking business. ${ }^{16}$ Although modern historians acknowledge the global and national economic circumstances prior to 1984, social and economic narratives have tended to focus upon the political changes of the 1980s and their consequences. The use of terms such as diversification and intensification are frequently synonymous with deregulation in the works of writers such as Roberta Mclntyre and Neal Wallace. ${ }^{17}$ This places too much emphasis on change from 1984 onwards, ignoring the presence of such practices in the past, both inside and outside of New Zealand. McAloon presented a reconciliatory argument: the years that followed 1984 marked the consolidation of a new international economy that had been developing since the 1960s, one in which national policy and business decisions were strongly determined by international markets. ${ }^{18}$

Agricultural produce was (and still is) New Zealand's primary export earner. In 1984 the Wairarapa region contained four percent of the country's cattle population, and five percent of its sheep population (184,686 cattle and 3,585,369 sheep, respectively). ${ }^{19}$ Although statistical information specific to only the South of the region did not become available until after the 1989 Local Government Act (LGA), comparison in numbers of sheep and cattle for the entire Wairarapa region between 1984 and 2014 is useful marker of change. ${ }^{20}$ The Wairarapa region is sixty percent hill country, unsuitable for cattle farming; ${ }^{21}$ despite this, sheep numbers more than halved in the period

\footnotetext{
${ }^{15}$ Smith and Montgomery, 'Revolution or Evolution? New Zealand agriculture since 1984'. p.117.

16 See, James, The Quiet Revolution.

Lewis Evans, 'Farming in a changing economic environment', in Allan Bollard and Robert Buckle (eds.), Economic Liberalisation in New Zealand, Allen and Unwin, Wellington, 1987. pp.102-121.

${ }^{17}$ See Mclntyre, Canoes of Kupe.

\& Wallace, When the Farm Gates Opened.

${ }^{18}$ McAloon, Judgements of all kinds. p.199.

19 James Gordon Spall, Diversification of Wairarapa Hill Country; potential for agroforestry, Thesis presented in partial fulfilment of the requirements for the Degree of Master in Agricultural Science, Massey University, Palmerston North, 1987. p.36.

20 See Figure 1.

${ }^{21}$ Boffa Miskell, Wairarapa Landscape Study 2010; Landscape Character Description, Greater Wellington Regional Council, August 2010. p.18. http://www.gw.govt.nz/assets/council-

publications/Wairarapa\%20Character\%20Study\%20August\%202010.pdf. (accessed 28/09/2016).
} 
1983-2014 while cattle numbers fluctuated before increasing by over twenty percent. This is a clear indication of a change in farming demographics within the region.

Fig.1

Sheep and cattle numbers 1984-2012

\begin{tabular}{|l|l|l|}
\hline Year to June $30^{\text {th }}$ & Sheep & Cattle \\
\hline 1984 & $3,585,369^{22}$ & $184,686^{23}$ \\
\hline 2003 & $1,701,655^{24}$ & $161,543^{25}$ \\
\hline 2012 & $1,571,843^{26}$ & $223,047^{27}$ \\
\hline
\end{tabular}

Three sectors of agricultural production have intensified, contracted and diversified in different ways in the past thirty years. The first sector, sheep and beef farming, in which production contracted, demonstrates a growing acknowledgement of the limitations of New Zealand agricultural productivism within the global market. The second sector, dairy farming, which replaced pastoral farming as the 'economic backbone of New Zealand', became a new avenue of productivist agriculture, encouraged by market knowledge and demand, new technologies and quasi-cooperative industrialisation in the form of the New Zealand Dairy Board and Fonterra. ${ }^{28}$ The third sector encompasses the diversification of primary industry within the South Wairarapa, and primarily concerned the rise of the viticulture and tourism. However, there has also been an expansion of the agriculture industry into the farming of alpaca, deer and goats.

\footnotetext{
${ }^{22}$ Spall, Diversification of Wairarapa Hill Country. p.36.

23 ibid.

${ }^{24}$ Statistics New Zealand, 'Sheep and Lambs Tailed by Age, Sex and Territorial Authority as at 30 June 2002', Agricultural Tables 2002, 3 July 2003. http://www.stats.govt.nz/browse for stats/industry sectors/agriculturehorticulture-forestry/2002-agricultural-census-tables/livestock.aspx. (accessed 1/04/2017).

${ }^{25}$ LIC, Dairy NZ, 'Regional Dairy Statistics, 2002-2004'. http://www.lic.co.nz/pdf/dairy stats/dairy stats 0203 section 3.pdf. (accessed 26/08/2016).

${ }^{26}$ Statistics New Zealand, 'Summary of Livestock by Type and Territorial Authority as at 30 June 2012', Agricultural Tables 2012. http://www.stats.govt.nz/browse for stats/industry sectors/agriculture-horticulture-forestry/2012agricultural-census-tables/livestock.aspx. (accessed 1/04/2017).

27 ibid.

${ }^{28}$ Conforte, Garnevska, Kilgour, Locke and Scrimgeour, 'The Key Elements of success and failure in the NZ Dairy Industry'. p.4.
} 
Statistics suggest that that the diversification of livestock provided supplementary income to farmers throughout the 1990s, but they are also indicative of increasing knowledge of science and markets. Diversification also encompasses the extent to which traditional agricultural practices became shaped by international market demand and competition, such as the cross breeding of livestock and the development of 'sustainable' and 'organic' farming practices.

\section{Keeping afloat}

Years of reliance upon Government support meant that following 1984, many farmers had to find new ways of responding to the harsh realities of the industry. Surveys conducted in 1982 and 1984 suggest that a practice of fattening livestock and sending them to early slaughter was common in the Wairarapa in the years prior to the withdrawal of farming subsidies. ${ }^{29}$ That Wairarapa farmers were beginning to downsize their farms suggests that they were feeling the economic strain of keeping surplus stock throughout the late 1970s; furthermore, it is evidence that diversification into dairy farming had not yet occurred in the region.

The contention by commentators such as Neal Wallace that farmers were first hit by the withdrawal of subsidies and second by Cyclone Bola in 1988 is inaccurate. ${ }^{30}$ Analysis of New Zealand's economic history by scholars such as James, Easton, Evans and McAloon has clearly demonstrated many hits to the farming economy from the 1960 s onwards. ${ }^{31}$ The Wool Crisis of 1966, Britain's accession to the EEC in 1973, the Oil Shocks of 1973 and 1978-79, and continuing balance of payments crises, had been affecting New Zealand's export economy for many years before $1984 .{ }^{32}$ Farmers had been aware of the un-sustainability of Muldoon's subsidies and SMP. In 1982 Federated Farmers President Peter Elworthy had asked Muldoon to focus economic policy on controlling the underlying causes of inflation and removing protection and assistance for all sectors. ${ }^{33}$ Furthermore, David Lange's Fourth Labour Government was not the first to implement cuts to the farming sector. In 1973 under Norman Kirk's Third Labour Government, Finance Minister Bill Rowling had cut the \$43

\footnotetext{
29 See, Baker and Todd, Consultants' Annual Report, Wairarapa Farm Improvement Club, Masterton, 1983 $\&$ W.J. Parker, A Study of Management Practices and Productive performance on a Sample of Hill Country Sheep Farms in North-East Wairarapa, Unpublished Masterate Thesis, Massey University, Palmerston North, 1984 in Spall, Diversification of Wairarapa Hill Country.

${ }^{30}$ Wallace, When the Farm Gates Opened. p.17.

${ }^{31}$ See, James, The Quiet Revolution.

Evans, 'Farming in a changing economic environment'. Brian Easton, In Stormy Seas; The Post-War New Zealand Economy, Otago University Press, 1997. \& McAloon, Judgements of all kinds.

${ }^{32}$ Le Heron and Pawson, Changing Places. p.21.

${ }^{33}$ Wallace, When the Farm Gates Opened. p.32.
} 
million dollar farm subsidy bill by two thirds. ${ }^{34}$ Muldoon himself had committed to abolishing SMP in the early 1980s. ${ }^{35}$ These observations do not downplay the economic ramifications of the 1984 reforms, but they do provide context and a historical perspective.

Fig. $2^{36}$

\section{Graph Showing Relative NZ Farm Income 1970-1984.}

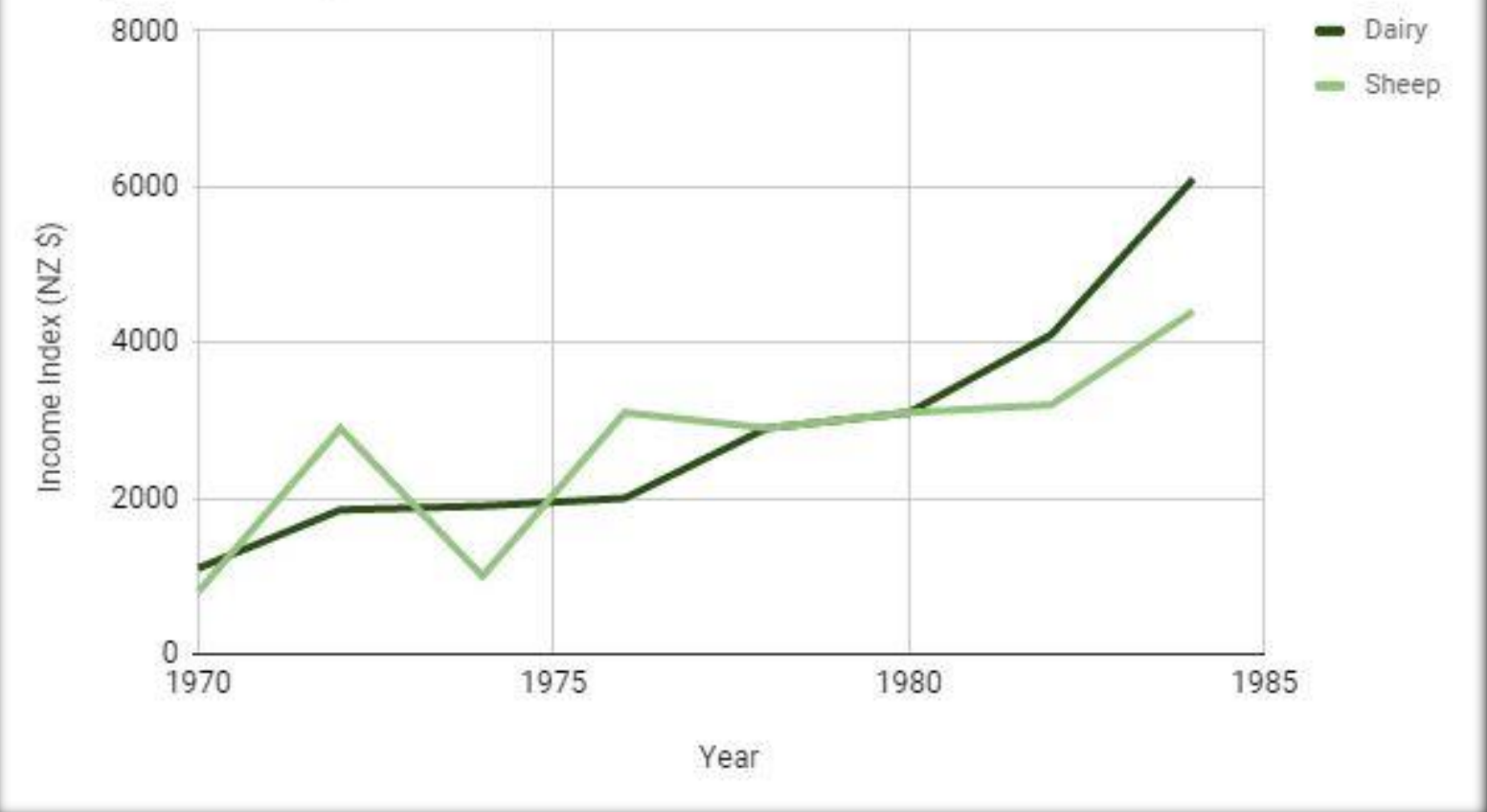

Following the Wool Crisis of 1966, Finance Minister Harry Lake began to emphasise the necessity for market and commodity diversification. ${ }^{37}$ Although pastoral exports continued to accrue the majority of overseas earnings from 1965 onwards, the actual incomes of sheep farmers fell relative to the incomes of dairy farmers. Rowling and Treasury saw high prices for farm exports as an opportunity to cut the Farm Subsidy in the 1973 Budget; ${ }^{38}$ however, they could not have foreseen the first Oil Shock that occurred in October of the same year, which McAloon has referred to as 'the final event in the causal chain of global recession'. ${ }^{39}$ In 1974 significant decrease in the income of sheep farmers, but not dairy farmers suggests that they were more vulnerable to the financial crisis which followed the oil shock; however, the same slump in income is not seen after the second Oil

\footnotetext{
${ }^{34}$ McAloon, Judgements of all kinds. p.153.

35 ibid. p.202.

${ }^{36}$ New Zealand Dairy Board, 'Supplements to the Sheep and Beef Farm Survey: Production and Financial analysis, an Economic Survey of Factory Supply Dairy Farms in New Zealand', in Evans, 'Farming in a changing economic environment'. p.114.

${ }^{37}$ McAloon, Judgements of all kinds. p.126.

38 ibid. p.153.

39 ibid. p.154
} 
Shock of 1978-79. This indicates that relative stability of pastoral incomes was contingent upon government intervention in the sector, and that the economic strain of the first Oil Shock was particularly felt by sheep farmers due to Rowling's axing of the Farm Subsidy Bill earlier that year. Even with the aid of subsidies and SMP, sheep farming incomes were unpredictable and significantly less than those of dairy farmers. While these figures do not account for those farmers who had traditionally run both sheep and cattle, it does present an imperative for pastoral farmers to expand into dairy farming. The withdrawal of government support for the agricultural sector in 1984 may have increased the urgency for pastoral farmers to diversify however, the reforms are not the sole cause of the intensification of dairy farming.

Although dairy farming has overtaken sheep farming as the predominant form of farming in the region, the number of sheep farms has not decreased to the extent that might be expected. The identification of the years that followed 1984 as 'characterised by a shift in favour of diversification, ${ }^{40}$ is an overstatement in the South Wairarapa. While there was a small amount of diversification in to alternative forms of farming, primarily viticulture, olive growing and forestry, agriculture clearly remained the dominant primary industry. ${ }^{41}$ Whether the survival of traditional pastoral farming in the region was a reflection of changing strategies of sheep farmers, or consequent of the economic circumstances, is an interesting question. The comparatively low income of sheep farmers coupled with the withdrawal of subsidies suggests a logical imperative for withdrawal from the industry; however, this did not happen in the short term. ${ }^{42}$

Economic hardship may have made diversification implausible for a number of traditional pastoral farmers. James Gordon Spall found in 1987 that development and capital expenditure were at a low in the region and that the primary concern of farmers was staying financially afloat. ${ }^{43}$ Many farmers had indebted themselves in the 1970s in response to the Muldoon administration's generous subsidies and emphasis on agricultural production. ${ }^{44}$ Between 1976 and 1980, 18,800 hectares of hill country had been cleared and developed under the Rural Banking and Finance Land Development Loan. ${ }^{45}$ The withdrawal of subsidies, exposure to market realities and end of interest

\footnotetext{
${ }^{40}$ Smith and Montgomery, 'Revolution or Evolution? New Zealand agriculture since 1984'. p.107.

${ }^{41}$ See figure 6.

42 See figure 2.

${ }^{43}$ Spall, Diversification of Wairarapa Hill Country. p.60

${ }^{44}$ Wallace, When the Farm Gates Opened. p.61.

${ }^{45}$ Spall, Diversification of Wairarapa Hill Country. p.60
} 
free loan schemes meant that farmers were not only struggling to keep on top of day-to-day costs, but were also accruing more debt.

A 1982 survey of a sample of 108 South Wairarapa pastoral farmers found that the majority of farmers listed financial incentives as a reason for their chosen profession, yet conversely the majority also listed financial instability as a disincentive for entering the farming sector. ${ }^{46}$ This suggests that farmers were aware of the potential economic hardships of farming but were willing to try to overcome them. There is little evidence to suggest that this attitude changed after 1984. While Wairarapa sheep farmers may have been struggling financially, there were no reported instances of bankruptcy. This suggests that they found other ways around the difficult economic climate, such as relying heavily on the traditional model of family farming, the labour capabilities of family members and community spirit. A 1984 survey of thirty pastoral farms in the South Wairarapa found that the average period of farm ownership was relatively short at twelve years, but that emphasis upon inter-generational family farming was common practice. ${ }^{47}$

Many commentators have hypothesised that an increased emphasis on family relationships, both on and off the farm, helped sheep farmers overcome the economic hardships that they faced after $1984 .{ }^{48}$ In the short term, the ability to rely on family based labour rather than hired labour was an important mechanism for cutting costs. ${ }^{49}$ Family was also significant in its capacity to generate off farm supplementary incomes. Only four percent of South Wairarapa farmers held qualifications beyond secondary school, but their wives tended to be more highly educated. ${ }^{50}$ While there was a decrease in the employment opportunities traditionally occupied by men, new work opportunities in the service sector presented greater work opportunities for women. ${ }^{51}$ The employment of farmers' wives provided a supplementary income to struggling households. ${ }^{52}$ Farmers also cut costs

\footnotetext{
${ }^{46}$ Field, T.R.O, Clark, D.A \& Brougham, R.W, Wairarapa Hill Country Survey, Unpublished D.S.I.R. Report, 1982 in Spall, Diversification of Wairarapa Hill Country. pp.37-38.

47 Parker, A Study of Management Practices and Productive performance on a Sample of Hill Country Sheep Farms in North-East Wairarapa in Spall, Diversification of Wairarapa Hill Country. p.37.

${ }^{48}$ See, Smith and Montgomery, 'Revolution or Evolution? New Zealand agriculture since 1984'. Neal Wallace, When the Farm Gates Opened.

\& Le Heron and Pawson, Changing Places.

${ }^{49}$ Smith and Montgomery, 'Revolution or Evolution? New Zealand agriculture since 1984'. p.108

${ }^{50}$ Parker, A Study of Management Practices and Productive performance on a Sample of Hill Country Sheep Farms in North-East Wairarapa in Spall, Diversification of Wairarapa Hill Country. p.37.

${ }^{51}$ Le Heron and Pawson, Changing Places. p.90.

${ }^{52}$ Wallace, When the Farm Gates Opened. p.26.
} 
and maintained morale by relying upon a sense of community, systems of trade and exchange replacing the purchase of new farming equipment. ${ }^{53}$

In 2014 the Reserve Bank issued a statement that New Zealand farmers were among the most indebted in the world. ${ }^{54}$ This may suggest that New Zealand's agricultural economy never recovered from the reforms; however, the four-fold increase in dairy farm debt between 2004 and 2014 is the principal explanation. ${ }^{55}$ This level of debt is somewhat surprising given that it was pastoral farming, and not dairy farming, that was the primary victim of the withdrawal of government subsidies. This Reserve Bank's statement is more indicative of the continuation of the post 1984 agricultural productivist dynamic driven by debt, rather than profit. ${ }^{56}$

Some have argued that social and economic distress was short-lived and that economic issues were resolved by the 1990s. External indicators such as input rates and land prices are generally used as the basis for these claims. ${ }^{57}$ Others have argued that ten years on, hill country farmers in particular were still facing extreme economic difficulty. ${ }^{58}$ Andrew Day of Federated Farmers Tararua suggested in 2012 that the most significant challenge to farmers was the amount of debt that they carried. ${ }^{59}$ The level of debt carried by farmers is an imprecise measure of the effects of the 1984 reforms. Debt has been a mainstay of New Zealand agricultural economy long prior to the reforms and foreseeably long after.

\footnotetext{
53 ibid. p.87.

${ }^{54}$ Dave Hansford, 'Water Liquidation', New Zealand Geographic, Issue 125, Auckland, January/February 2014. p.47.

55 ibid.

56 ibid.

${ }^{57}$ Smith and Montgomery, 'Revolution or Evolution? New Zealand agriculture since 1984'. p.107-110.

58 ibid. p.109.

${ }^{59}$ Don Farmer, 'Environmental stand made passage bumpy', Wairarapa Times Age in Alan Wilde's private collection of writings and newspaper clippings, Greytown.
} 
From mutton to milk

Fig. $3^{60} \quad$ South Wairarapa Farm Holdings and Stock Numbers 1990-1996

\begin{tabular}{|l|l|l|l|l|}
\hline Year & $\begin{array}{l}\text { Number of Farm } \\
\text { Holdings }\end{array}$ & $\begin{array}{l}\text { Total Dairy Cattle } \\
\text { (including Bobby } \\
\text { Calves) }\end{array}$ & Total Beef Cattle & Total Sheep \\
\hline 1990 & 585 & 28,748 & 61,741 & 759,973 \\
\hline 1991 & 583 & 30,165 & 64,958 & 757,998 \\
\hline 1992 & 546 & 31,102 & 61,698 & 673,204 \\
\hline 1993 & 546 & 31,688 & 65,238 & 650,312 \\
\hline 1994 & 493 & 35,538 & 69,482 & 619,144 \\
\hline 1995 & 484 & 37,309 & 63,418 & 683,736 \\
\hline
\end{tabular}

${ }^{60}$ Statistics New Zealand; Infoshare, 'Variable by Territorial Local Authority(Annual-Jun); South Wairarapa District, Number of Farm Holdings, Total Dairy Cattle (including Bobby Calves), Total Beef Cattle, Total Sheep, 1990-1996'. http://www.stats.govt.nz/infoshare/ViewTable.aspx?pxID=aca2a10b-486f-4bee-9d3d-f40f90d76ffe. (accessed 30/4/2017). 
Fig. $4^{61}$

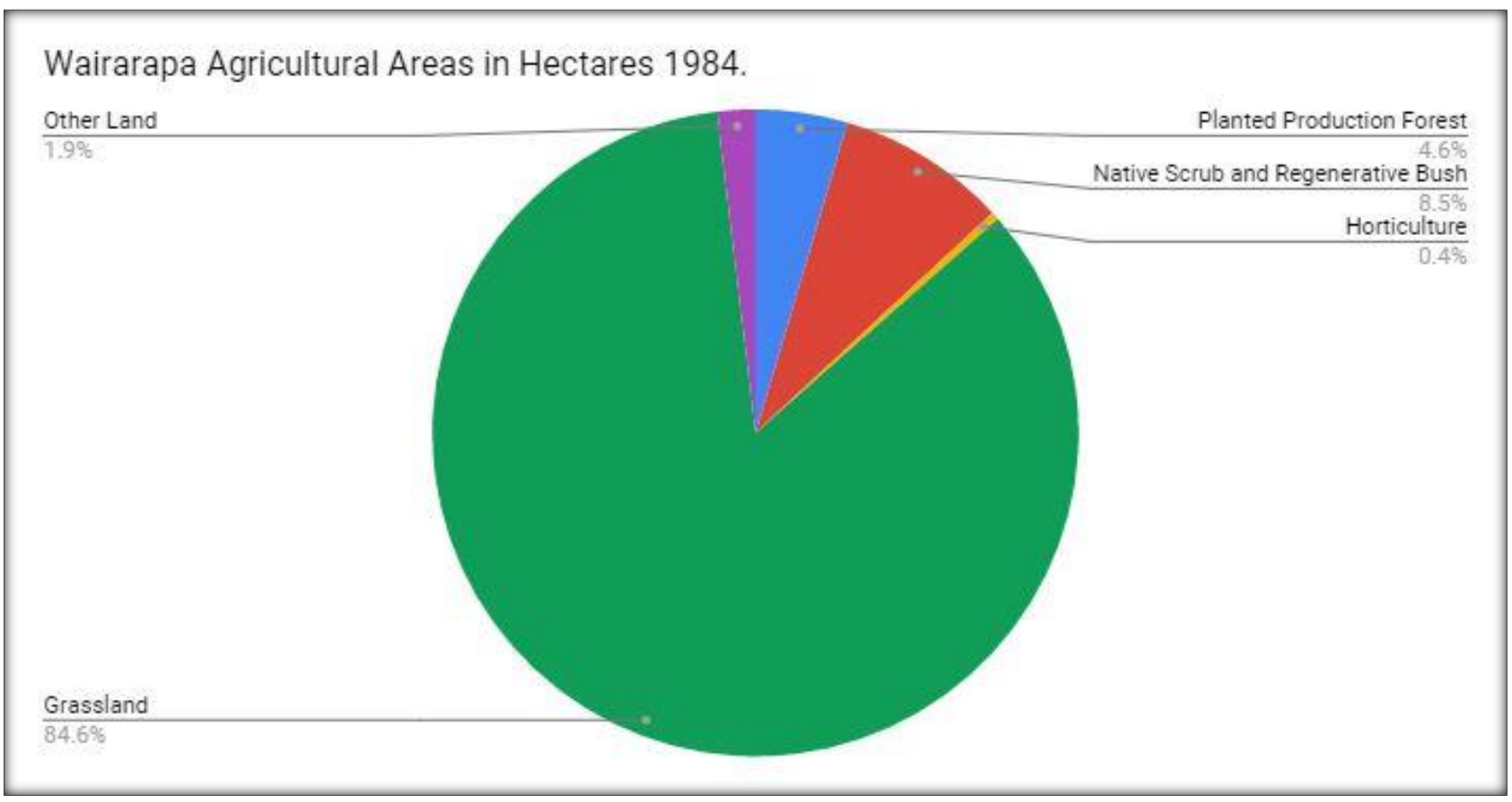

Fig. $5^{62}$

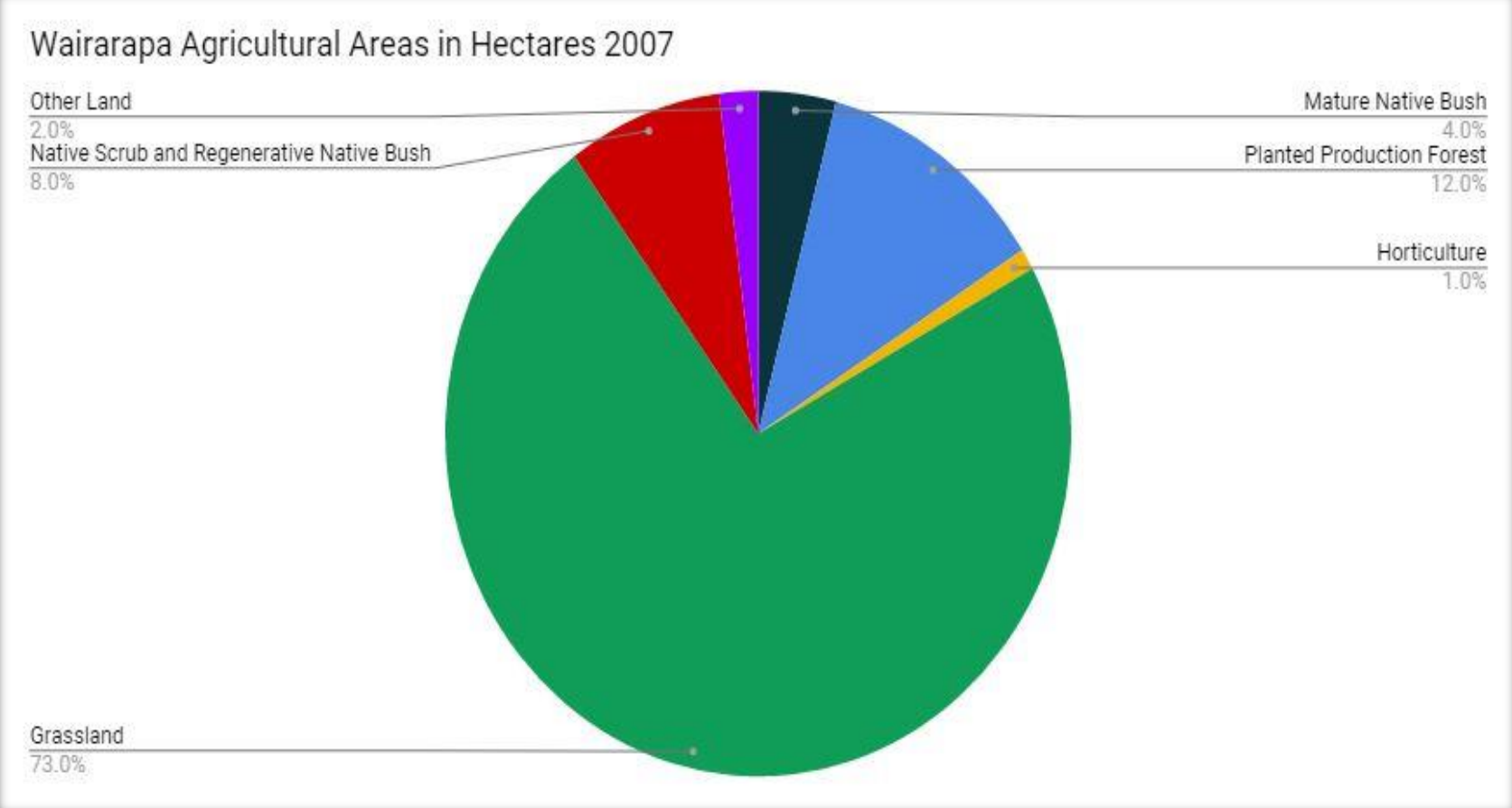

${ }^{61}$ Spall, Diversification of Wairarapa Hill Country. p.26.

${ }^{62}$ Statistics New Zealand, 'Wairarapa agricultural areas in hectares, by useage at 30 June 2007', 2007 Agricultural Census. http://www.stats.govt.nz/browse for stats/industry sectors/agriculture-horticultureforestry/2007-agricultural-census-tables/land-use-farm-counts.aspx. (accessed 20/03/2017). 
Dairy farming was not common in the South Wairarapa prior to the 1990s. The Farm Monitoring Report of December 1986 reported no milkfat sales in the region and no dairy shed expenses between 1984 and its time of publication. ${ }^{63}$ Yet by 1990 the Statistics New Zealand Agricultural Survey recorded 28,748 dairy cattle in the region. ${ }^{64}$ Diversification did not happen overnight, and a reasonable transition period from sheep and beef farming to dairy farming was to be expected. That there was no dairy shed expense prior to 1986 suggests two things. Diversifying farmers may have cut costs by making use of the facilities and resources already available to them, prioritising the purchase and rearing of stock until they were in a position to begin milking commercially. Alternatively, there may simply have been a boom in the purchase and rearing of dairy cattle between 1986 and 1990. Regardless of when the diversification into dairy farming occurred, six years later the South Wairarapa District was home to 37,309 dairy cows. ${ }^{65}$

Between 1990 and 1996, the total number of farm holdings and the total area of farmland in the region reduced significantly. ${ }^{66}$ This is partly explainable by the twenty percent decrease in the sheep population. However, statistics for the region are congruent with national statistics for the same period, which show an increase in dairy herd size and a decrease in the number of herds. ${ }^{67}$ While many commentators cite the withdrawal of government subsidies as the reason for the decline in pastoral farming, medium term statistics suggest that the decline was a response to realisation of the continuing decline in the value of wool and lamb on international markets. ${ }^{68}$ International demand and comparatively higher prices for products such as casein and milk powder provided an economic incentive for diversification in to dairy farming. ${ }^{69}$

Transition to dairy farming was slow, but picked up in the twenty years following 1996, overtaking sheep farming as the primary industry in the region. ${ }^{70}$ Researchers from Lincoln University's

\footnotetext{
${ }^{63}$ MAF, Farm Monitoring Report, Wellington, December 1986, in W.J. Parker, in James Gordon Spall, Diversification of Wairarapa Hill Country; potential for agroforestry, Thesis presented in partial fulfilment of the requirements for the Degree of Master in Agricultural Science, Massey University, Palmerston North, 1987. p.44.

${ }^{64}$ Statistics New Zealand; Infoshare, 'Variable by Territorial Local Authority (Annual-Jun); South Wairarapa District, Total Dairy Cattle (including Bobby Calves), 1990-1996'.

http://www.stats.govt.nz/infoshare/ViewTable.aspx?pxID=aca2a10b-486f-4bee-9d3d-f40f90d76ffe. (accessed 30/4/2017).

65 ibid.

66 See figures 4, 5 and 6.

${ }^{67}$ LIC, Dairy Statistics 2000/01, Hamilton, 2001. p.10. http://www.lic.co.nz/pdf/dairy stats/dairy stats 2002.pdf. (accessed 25/04/2017).

${ }^{68}$ Statistics New Zealand, '1999 Agricultural production: national and regional changes', Key Statistics, August 2000. p.8. http://www.stats.govt.nz/browse for stats/industry sectors/agriculture-horticulture-forestry/1999-agriculturalproduction-national-regional-changes.aspx. (accessed 20/04/2017).

69 ibid.

${ }^{70}$ See figure 4.
} 
Agribusiness and Economics Research Unit highlighted three fundamental stimuli for the intensification of dairying in New Zealand. The first pertained to the development of specific agribusiness. Access to new information and technology facilitated the opening of the markets and enabled farmers to work with scientists to formulate products that met international market demands. ${ }^{71}$ The second reflected the extent to which the New Zealand Dairy Board and Fonterra mimic the dynamic of the pre-1984 producer marketing boards. In appealing to the traditional notion that control of the eco-commodity chain should remain in the hands of farmers for as long as possible, these infrastructures alleviated the fear of corporate domination among dairy farmers. ${ }^{72}$ Lastly, waning British interest in New Zealand commodities and the enlargement of the EEC after 1973 triggered the development of competitive global networking, in which New Zealand exports became dependent on a wider base encompassing China, Russia, Mexico, Japan and the USA. ${ }^{73}$ All three of these factors suggest that external economic factors, rather than internal economic restructuring, drove the intensification of dairy farming

\footnotetext{
${ }^{71}$ Wallace, When the Farm Gates Opened. p.9.

72 Smith and Montgomery, 'Revolution or Evolution? New Zealand agriculture since 1984'. p.124.

${ }^{73}$ Conforte, Garnevska, Kilgour, Locke and Scrimgeour, 'The key elements of success and failure in the NZ dairy industry'. p.4.
} 
Fig. $6^{74}$

\section{Farm Types in the South Wairarapa District, New Zealand by industry classification, as at June 2012.}

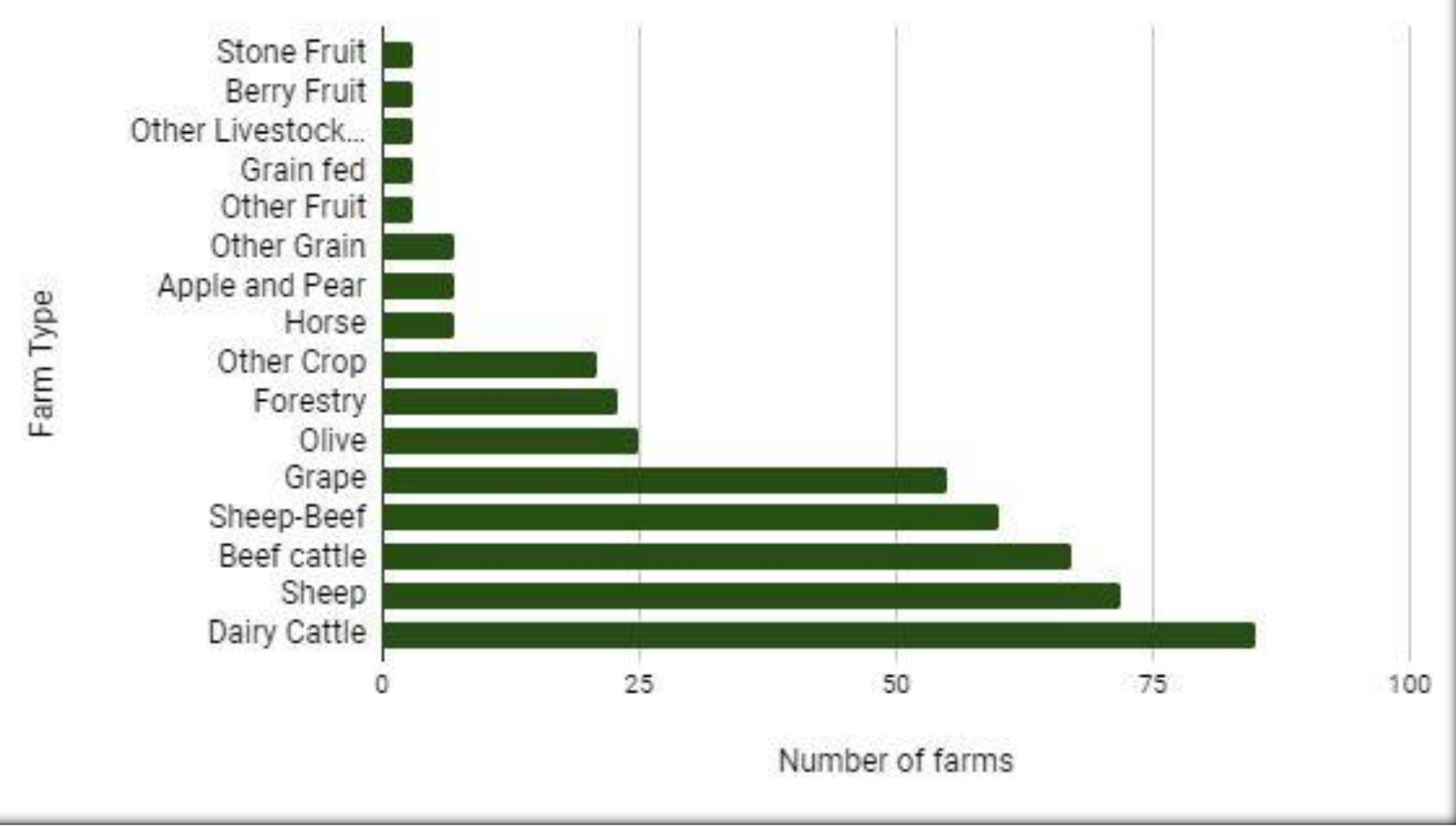

Although numbers continued to be negligible in comparison to those of cattle and sheep, numbers of alternative livestock also increased. Diversification necessarily entailed consideration of what alternative forms of livestock would be economical. Unlike some other parts of New Zealand, the South Wairarapa did not experience a rise in deer farming. ${ }^{75}$ There were probably several reasons for this, mainly pertaining to the high cost-low returns nature of deer farming, bureaucratic limitations and the necessity to graze deer separately from other livestock. ${ }^{76}$ The experiences of sheep farmers Barbie and Roger Barton are demonstrative of the benefits that stock diversification could have during times of economic duress. Responding to investment hype for cashmere and mohair, the South Wairarapa farmers began an embryo transferring business between angora does and feral goats. They claim that goats saved their business. ${ }^{77}$ On a technical level goats were a viable

\footnotetext{
${ }^{74}$ Figure. NZ, 'Farm Types in the South Wairarapa District, New Zealand; By Industry Classification, as at June 2012, number of farms', Statistics New Zealand. https://figure.nz/chart/rlwyvzqecliuvVqY-x2Y8mxK0L7R3nq1D. (accessed 24/4/2017).

$75 *$ Deer farming across New Zealand rose by $58 \%$ between 1990 and 2000.

Statistics New Zealand, 'Deer numbers in New Zealand as at June 30, from 1971'. http://maxa.maf.govt.nz/statistics/pastoral/livestock-numbers/. (accessed 28/09/2016).

${ }^{76}$ Antoon De Vos, '4.2: Deer Behaviour as related to management', Deer Farming; guidelines on practical aspects, Food and Agriculture Organization of the United Nations, Rome, 1982.

77 Wallace, When the Farm Gates Opened. p.85.
} 
choice for the Bartons: mixed sheep and goat pasture compositions had proven to be good for soil and grass composition and required little to no extra investment. ${ }^{78}$ Response to market demand also played an important part in the Bartons' diversification decision: the market knowledge that informed their business was precisely that which would have been difficult to ascertain prior to economic restructuring. Furthermore, the diversification of traditional pastoral farming into crossbreeding and reproductive science is emblematic of the scientific knowledge production facilitated by the opening of the markets. ${ }^{79}$ The ability to 'save' a business through diversification poses the question of whether an earlier opening of the New Zealand markets would have prevented the product surpluses and economic stagnation that the country faced throughout the 1970 s.

\section{To market, to market}

The New Zealand agricultural sector experienced a subjective shift in the nature and management of market commodities from the 1980s onwards. The 'New' agricultural politics were determined not by domestic markets but by international concepts of qualities and values. ${ }^{80}$ Audit schemes and new forms of agri-food business replaced the agricultural governance of producer-marketing boards, emphasising the agency of the consumer over that of the producer. ${ }^{81}$ In competition with commodities from other nations, New Zealand products became increasingly shaped by to the subjectivities of consumers. ${ }^{82}$ Large farms supplying meat and dairy products for export became subject to audit systems such as the Quality Mark and initiatives such as Fonterra's Clean Streams Accord. ${ }^{83}$

The majority of South Wairarapa farms and producers became subject to the audit schemes of the 'new' agricultural politics. There was also a significant increase in the number of small-scale farms marketed as 'eco' and 'green' businesses; however, these businesses operated primarily on a

\footnotetext{
${ }^{78}$ D.A. Clark, M.P. Rolston, M.G. Lambert, P.J. Budding, 'Pasture composition under mixed sheep and goat grazing on hill country', Proceedings of the New Zealand Grasslands Association, 45, 160-1, 66, Palmerston North, 1984. p.165.

${ }^{79}$ Catriona J MacLeod, Henrik Moller, 'Intensification of New Zealand Agriculture since 1960: An evaluation of current indicators of land use change', Agriculture, Ecosystems and Environment, 115, 2006. p.212.

${ }^{80}$ Hugh Campbell, Rob Burton, Mark Cooper, Matthew Henry, Erena Le Heron, Richard Le Heron, Nick Lewis, Eric Pawson, Mike Roche, Chris Rosin \& Toni White, 'From agricultural science to "biological economies"?', New Zealand Journal of Agricultural Research, 52:1, 2009. p.90.

81 'ibid.'

82 Hugh Campbell, 'A Sociology of Agriculture for Crunch Times: Sustainability, Dialogue, and the Disciplinary Politics of Knowledge Production in New Zealand Farming', New Zealand Sociology, Vol.24, No.2, 2009. p.34.

${ }^{83}$ Rod Slater (ed.), Beef and Lamb New Zealand Reference Guide, 3rd edition, 2010. p.3. http://www.beeflambnz.co.nz/resources/Reference Guide.pdf and Dairy NZ, 'Sustainable Dairying: Water Accord', http://www.dairynz.co.nz/environment/in-your-region/sustainable-dairying-water-accord/.
} 
community level. This demonstrates the protean nature of consumer New Zealand's domestic agricultural community. A growing awareness of environmental issues emerged within the national market, yet more often than not these patterns of consumption continued to take place at a cooperative, community level. ${ }^{84}$ Farmers markets and similar business models meant that the point of sale remained at a local level and was social movement based, rather than market driven.

\section{Restructuring social space?}

A significant consequence of the 1984 reforms was a change in the social fabric of the South Wairarapa. Farmers no longer held the political capital that they had enjoyed throughout the twentieth century, and subsequently had to rely on traditional notions of rural community in order to justify their existence. Economic hardship consequent of the withdrawal of subsidies, debt and rising primary sector unemployment had a substantial impact on community and family dynamics. Yet the subjectivities of farmers toward their farming practices remained largely unchanged. For the most part there was a continuation of the national trend of productivism. While there were tangible changes in the structuring of communities and households the subjectivities of farmers and their farming practices changed very little.

Richard Le Heron and Eric Pawson rightly stated that the discussion of restructuring, both in the 1980s and in subsequent years, was often discussed in terms abstract from social consequences and relationships. ${ }^{85}$ Contemporary reflections of the time and farmer subjectivities echo this statement. Many farmers felt that the withdrawal of subsidies would have been manageable, were it not compounded by significant re-structuring elsewhere. ${ }^{86}$ A lack of faith in policy makers' understanding of social realities was arguably not specific to economic restructuring in the 1980s. Within a capitalist system, social change becomes defined by changes in relations of production and consumption. ${ }^{87}$ The effects of this are particularly evident within New Zealand's rural communities, where the cultural, political and economic capital of farmers is subject to the yo-yoing effect of external economic factors such as government policy, fluctuating markets and international competition. In the South Wairarapa, a region characterised by pastoral farming and agricultural industry, changes in relations of production and consumption affect not only farmers but also rural communities as a whole. The removal of subsidies and producer marketing boards in 1984 were

\footnotetext{
${ }^{84}$ Brooking and Pawson, Making a new land. p. 21.

${ }^{85}$ Le Heron and Pawson, Changing Places. p.5.

${ }^{86}$ Smith and Montgomery, 'Revolution or Evolution? New Zealand agriculture since 1984'. p.109.

${ }^{87}$ Le Heron and Pawson, Changing Places. p.5.
} 
political decisions symptomatic of global free market capitalism and New Zealand's place within that system.

One need only look at the transformation of political discourses concerning agriculture to understand the assault on farmers' economic and political capital. For many years, farmers had been the backbone both of the economy and of National Party support. ${ }^{88}$ Before any policy had been announced, conveyance of power to Fourth Labour in 1984 engendered perceptions of a downturn in farmer levels of political capital. ${ }^{89}$ The withdrawal of subsidies and producer boards and the painting of agriculture as a 'sunset industry' by the new government compounded these perceptions. ${ }^{90}$ This change in relations between producers and governance was most evident at a community level. Roger and Barbie Barton stated that the support networks within the community were essential to the survival of their farm throughout the 1980 s and 1990 s. $^{91}$ Political and economic capital of the farming industry fell away as its incompatibility with international market trends was exposed.

The persistence of cultural capital held by farmers within the South Wairarapa proved essential to the continuation of agricultural industry. Economic hardship was lessened and community ties strengthened by knowledge and equipment sharing, in particular under the guidance of older more established farmers. ${ }^{92}$ There is also evidence to suggest that this is why attitudes toward agricultural productivism remained unchanged. There is a perceptible, although not unchallenged continuation of the long-standing agricultural narrative that equates productivism with good farming. ${ }^{93}$ While making more of less was an economic necessity, it was also a longstanding tradition within the community.${ }^{94}$ The intensification of dairy farming and present day emphasis on agricultural exports are evident of a continuation of productivist economics and an upturn in the level of political and economic capital enjoyed by farmers.

The significant reduction in the economic capital of farmers was a key driver of demographic change in the South Wairarapa. The local economies of towns such as Martinborough, Featherston and Greytown were linked to rural agricultural industry. ${ }^{95}$ The reduced purchasing power of farmers

\footnotetext{
${ }^{88}$ Barry Gustafson, His Way; A Biography of Robert Muldoon, Auckland University Press, 2000. p.246.

${ }^{89}$ Wallace, When the Farm Gates Opened. p.13.

${ }^{90}$ Smith and Montgomery, 'Revolution or Evolution? New Zealand agriculture since 1984'. p.117.

${ }^{91}$ Wallace, When the Farm Gates Opened. p.87.

92 ibid.

${ }^{93}$ Haggerty, Campbell and Morris, 'Keeping the stress of the sheep? Agricultural intensification, neoliberalism and 'good' farming in New Zealand'. p.769.

${ }^{94}$ ibid. p.773.

${ }^{95}$ Wallace, When the Farm Gates Opened. p.24.
} 
resulted in a drop in expenditure on rural services and employment. ${ }^{96}$ Unemployment levels rose in the region, as farms increasingly became a family affair with a decline in hired farm labour, and associated agricultural industries closed. ${ }^{97}$ An unknown number of farmers left rural communities seeking work in urban or industrialised areas such as Wellington and the Hutt Valley. ${ }^{98}$ An increase in the Wellington service industry further spurred the migration of people away from the South Wairarapa. The train became an important part of local infrastructure for those who sought work over the Rimutakas but did not leave the region. ${ }^{99}$ Yet the distance of Martinborough and smaller rural communities from the mainland railroad made this an expensive and un-inviting prospect for many residents. ${ }^{100}$ Were it not for the continuation of agricultural production and the diversification of the region's industries into viticulture and tourism, the South Wairarapa would have become a region in decline. ${ }^{101}$

The restructuring of the New Zealand economy played an important role in exposing, and changing, the predominant cultural foundation of the nuclear family. ${ }^{102}$ Within this dynamic, women were responsible for the reproductive roles, raising the next generation of workers, cooking and cleaning for men who were involved in productive work. ${ }^{103}$ Carolyn Merchant has identified that when changes in production occur, the dynamic between the culturally normative 'female roles' and 'male roles' can be transformed. ${ }^{104}$ While it is inaccurate to state that women did not work outside the home prior to 1984, the restructuring of the agricultural sector had major implications for production, which in turn affected the nature of reproductive work. Slumps in farming income and agricultural industry resulted in many women entering work in the service sector, a trend that Richard LeHeron and Eric Pawson termed 'the Feminization of the workforce. ${ }^{105}$ In an attempt to lower farm expenditure women also began to play a more active role in the family business. ${ }^{106}$ However, this change in production dynamics rarely subverted the reproductive/productive work roles of men and women, rather women assumed both a reproductive and productive role within the economic

\footnotetext{
${ }^{96}$ Smith and Montgomery, 'Revolution or Evolution? New Zealand agriculture since 1984'. p.109.

97 Wallace, When the Farm Gates Opened. p.13.

${ }^{98}$ Wallace, When the Farm Gates Opened. p.18.

${ }^{99}$ Adrienne Staples (ed.), Featherston County New Zealand; visitor guide, 2nd edition, Featherston 1/5/2006. p.8.

100 Mclntyre, Canoes of Kupe. p.252.

${ }^{101}$ Katie Farman, 'Martinborough, Outside The Square', Fishhead Magazine, Oct/Nov 2011, p.42-44, Microfilm, Wgtn City Libraries N0518678628. p.43.

102 Le Heron and Eric Pawson, Changing Places. p.90.

103 ibid.

${ }^{104}$ Carolyn Merchant, 'The Theoretical Structure of Ecological Revolution', Environmental Review: ER, Vol.11, No.4, Special Issue: Theories of Environmental History, winter 1987. p.271.

105 Le Heron and Pawson, Changing Places. p.98.

${ }^{106}$ Smith and Montgomery, 'Revolution or Evolution? New Zealand agriculture since 1984'. p.108.
} 
dynamics of the household. ${ }^{107}$ The cultural normative framework of the nuclear family, not being specific to New Zealand, is still a widely held Western ideal. However, changing social and cultural relations within global frameworks of production have necessitated, and facilitated, the emergence of a growing female workforce.

Susan M. Shipley's research report Women's Employment and Unemployment focuses on Palmerston North and provides an important social context for the employment demographic of New Zealand women prior to 1984. While outside of the geographical scope of this study the findings are likely to be representative of trends across New Zealand at this time. In 1982 women constituted four fifths of the part-time workforce in Palmerston North. ${ }^{108}$ This statistic also accounts for single and widowed women, however they were more likely to partake in, or be actively seeking, full-time employment. It suggests that there had been imperatives for women to partake in employment subsidiary to their husband's prior to restructuring. Shipley's findings also show that there were a significantly higher number of unemployed females seeking work than there were males. ${ }^{109}$ This indicates that female willingness to enter the workforce predates economic restructuring, but that gender biased subjectivities may have prevented it. While the economic fragility of agricultural households may have driven women into the workforce post 1984 it is important not to overlook the cultural, social and economic circumstances that pre-dated this drive. The perspective of 'individuals in relation' defines aptly the desires of women to attain economic independence from their partners. ${ }^{110}$ This strong cultural determinant provides an additional explanation for the growth of women in the workforce post 1984.

\footnotetext{
107 Prue Hyman, Women and Economics: A New Zealand Feminist Perspective, Bridget Williams Books, Wellington, 1994. p.177.

${ }^{108}$ Susan. M. Shipley, Women's Employment and Unemployment: a research report, Massey University Department of Sociology and The Society for Research on Women in New Zealand inc, Palmerston North, 1982. p.5.

109 Shipley, Women's Employment and Unemployment. p.7.

${ }^{110}$ Hyman, Women and Economics. p.161.
} 


\section{Conflict and commodification of nature}

As agricultural industry intensified so did conflict over the value and usage of the region's natural resources. Consumer demand and emerging evidence of environmental degradation generated discussions about resource use and distribution in the region. Sustainability is emphasised by many consumers, individuals and interest groups within the community. However, proposals for environmental protection are regarded as incompatible with the traditional productivist farming methods preferred by many South Wairarapa farmers. Legislation aimed at making agricultural industries more environmentally accountable is reported as being largely inefficient, ignored and unimplemented. While many audit schemes have sustainability criteria they are not wide in scope, are often only partially implemented or exist primarily for marketing reasons. Many scientists and other commentators have attributed the degradation of fresh water resources to agricultural intensification. There is an ongoing conflict in the region between the economic significance of agricultural industry and the physical, cultural and spiritual value of the natural environment.

Contrasting social objectives and goals amongst societal actors may muddle the implementation of environmental policy. Grey areas in discourse are complicated further when economic and political objectives become involved as is inevitable with regard to the New Zealand agricultural sector. Discourses' surrounding what is valued and how it should be valued are increasingly pertinent in New Zealand society. The incapability of producers, bureaucracy and legislation to reconcile subjective notions of sustainability, and in turn objective notions of growth, is argued by many to embody the American ecologist Garret Hardin's Tragedy of the Commons, a process in which individuals acting for personal gain overuse, and ultimately destroy the resources upon which they rely. ${ }^{111}$

Notions of cultural, political and economic capital are particularly pertinent to allocation of -and access to- resources, both humanly produced and given in nature. Within the social space of the South Wairarapa, much of the debate around the appropriate use of resources becomes manifested into struggles for political and cultural capital. A significant point of contention within the region has been the resource allocation of freshwater. Extensive irrigation is not a consequence of neoliberal reform, but changes in land use and market demand have altered the role of irrigation within New Zealand's environment. The diversification of agricultural industry and the expansion of dairy farming to dryland areas such as the Wairarapa plains elevated the role of irrigation from an

\footnotetext{
${ }^{111}$ Harvey, Justice, Nature and the Geography of Difference. p.154.
} 
occasional means of alleviating drought pressures to an ongoing facilitator of 'sustainable' agriculture. ${ }^{112}$ For dryland dairy farmers irrigation is a necessary means of producing their market product, and thus accruing economic capital. ${ }^{113}$ However, a 2014 Horizon's Research survey conducted in a neighbouring region found that only forty-nine percent of respondents thought that dairying was a sustainable industry. ${ }^{114}$ Here in lies a primary conflict in the notion of sustainability: what is economically sustainable for one group may not be socially or culturally sustainable for another.

Discussing the management of water in the Canterbury region Dave Hansford wrote 'the instant a raindrop hits the ground on the easterly side of the Alps it becomes a commodity, coveted and fiercely contested. ${ }^{\prime 115}$ Although South Wairarapa drought conditions have not reached Canterbury levels, projected weather changes for the Wairarapa over the next twenty-five years suggest that they are that way headed. ${ }^{116}$ This is of concern to many residents who already experience water restrictions during the summer months. Retired Greytown farmer Alan Wilde wrote to the Wairarapa Times in January 2015, '(The) council advised us to avoid water evaporation by watering gardens early in the evening, or early in the morning rather that in the heat of the day....and it asks us to please conserve this special resource. However, it seems to exclude dairy farmers, who carry on watering in 30 degree temperatures right throughout the day until the council tell them to stop!' ${ }^{117}$ Perceived double standards over the right to utilise water are exacerbated by the fact that the taxpayer funds national irrigation schemes. ${ }^{118}$ Furthermore, after paying an allocation fee to access bores, farmers are able to store any excess water that they do not use, and sell it at a price. ${ }^{119}$ Water in the Wairarapa has already become a social commodity, if not an economic one. The cultural and political capital held by farmers in New Zealand determines that water remains an

\footnotetext{
112 Jim McAloon, 'Merino, Mussels and Merlot: New Zealand's thriving resource-based economy?' Conference paper, Asia- Pacific Economic and Business History Conference, Adelaide, February 2016.

${ }^{113}$ MAF, The Economic Value of Irrigation in New Zealand, Technical Paper No: 04/01, ISBN No: 0-478-07798-X, April 2004. http://ecan.govt.nz/publications/Reports/cwms-tech-rpt-3b-Economic-value-of-Irrigation-Apr-04-final.pdf. (accessed 26/07/2016). p.5.

$114 *$ Horizon regional council encompasses Whanganui. Manawatu and the North Wairarapa, these statistics do not necessarily reflect the perspectives of South Wairarapa residents.

Horizon Research, Farming and the Environment, Conducted for Fish and Game New Zealand, Palmerston North, January 2014. p.13.

${ }^{115}$ Hansford, 'Water Liquidation'. p.38.

${ }^{116}$ Ministry for the Environment, 'Climate Change Projections for the Wellington and Wairarapa Region', 30/06/2016. http://www.mfe.govt.nz/climate-change/how-climate-change-affects-nz/how-might-climate-change-affect-myregion/wellington. (accessed 05/10/2016).

${ }^{117}$ Alan Wilde, Letter to the Editor of the Wairarapa Times, 13/01/2015, Alan Wilde's private collection of writings and newspaper clippings, Greytown.

${ }^{118}$ Hansford, 'Water Liquidation'. p.38.

119 ibid. p.41.
} 
accessible resource for the continuation of production; it is a crucial asset in achieving the government's economic growth agenda. ${ }^{120}$ However, for other residents it is a 'special resource' to be conserved and used sparingly.

The uneven distribution of water as a resource is part of a much larger societal debate pertaining to the nation's freshwater. Massey University freshwater ecologist Russell Death stated 'it's nearly universal around freshwater scientists that water quality in New Zealand has been declining for upwards of 25 years. ${ }^{121}$ In email correspondence, Dr Death asserted that the twofold increase in dairy stocking rates were primarily the cause of this. ${ }^{122}$ Death is not alone in this assertion, he has been widely agreed with by scientists, politicians and farmers alike.

The contamination of water bodies due to agricultural intensification is a recent consideration. There is little evidence of it being an issue prior to the intensification of dairy farming. To an extent widespread concern attributed to the decline in water quality can be attributed to the rise in 'environmental' considerations over the 1980s and 1990s. ${ }^{123}$ The manipulation of the natural world for human purposes has been the practice of humans for millennia, and to state that the intensification of other agricultural industry over the past four hundred year has had no environmental implications is absurd. ${ }^{124}$ Intensification in and of itself is not the prime cause of recent water degradation, it is the nature and management of the stock that has being intensified. In 2010 NIWA reported that water quality in New Zealand's major rivers had declined between 1989 and 2007. Over that period nitrogen and phosphorus loadings had increased greatly at many sites; ${ }^{125}$ several scientific findings attribute this to dairy farming. Increased levels of nitrate, particularly from cows feeding on palm kernel, can enter water from direct deposits through drainage systems and by leaching through the soil. Similarly, phosphorus enters water bodies through sediment runoff and direct deposits of dung in the waterways. ${ }^{126}$ At elevated rates, both nutrients can adversely affect the safety of water for drinking, the health of freshwater ecosystems, and the leisure and

\footnotetext{
120 ibid. p. 38.

121 John Campbell, 'Dr Russell Death; Fresh water results worst ecology professor has seen', CheckPoint, RNZ National, 22/8/2016. http://www.radionz.co.nz/national/programmes/checkpoint/audio/201813133/fresh-water-resultsworst-ecology-professor-has-seen. (accessed 4/09/2016).

122 Eleanor Rainford, Email correspondence with Dr Russell Death, Monday 3rd October, 2016.

123 Le Heron and Pawson, Changing Places. p. 273.

${ }^{124}$ Harvey, Justice, Nature and the Geography of Difference. p.125.

125 Hansford, 'Water Liquidation'. p.46.

${ }^{126}$ Greater Wellington Regional Council, A guide to managing stock access to waterways in the Wellington Region, August 2011. p.7.
} 
aesthetic qualities of the water bodies. ${ }^{127}$ The presence of E-Coli, which accesses waterbodies in the same way as the nutrients mentioned prior, has become of national concern in recent years after outbreaks of gastrointestinal illness in areas of Canterbury, and most recently Havelock North. ${ }^{128}$ The adverse effects of agricultural intensification upon physical health widened concern beyond traditional green subjectivities.

What is troublesome is that Fonterra, Local, and Regional Government have been aware of the adverse effects of dairy farming for a number of years. The Dairying and Clean Streams Accord was an agreement signed in 2003 between Fonterra, The Ministry for the Environment, Ministry of Agriculture and Forestry and Regional Councils. The stated goals of the accord were to achieve clean healthy water, including streams, rivers, lakes, groundwater and wetlands, in dairying areas. ${ }^{129}$ The Dairying and Clean Streams Accord explicitly stated as one of its five targets the removal of cattle from ninety percent of waterways by $2012 ;{ }^{130}$ however, this has not been implemented.

Critics have argued that the lack of implementation of regulatory rules regarding cattle around water bodies is concomitant of voluntary participation clauses. For South Wairarapa farmers Grant Muir and Alan Wilde knowledge of the adverse effects of their farming practices on water quality appealed to their social and environmental subjectivities. Numerous reports of stock in waterways and significantly raised nutrient levels in the Ruamāhanga Whaitua are evidence that farmer subjectivities are not congruent throughout the region. ${ }^{131}$ Under the RMA the responsibility of managing water resources in the public interest lies with regional councils. Wilde and Muir have both reflected upon the GWRC's inefficacy in holding accountable those whose cattle continue to access and pollute waterways. ${ }^{132}$ Neither the RMA nor the Clean Streams Accord outlaw the access of stock to waterways. Furthermore, section 14.1 of the RMA states that fresh water may be used to meet 'the reasonable needs of an individual's animals for drinking water', providing that it does

\footnotetext{
${ }^{127}$ Tessa Bunny, Juliet Milne and Laura Keenan, River water quality and ecological health in the Ruamāhanga Whaitua, Ruamahanga Whaitua Committee; Wairarapa, Masterton, July 2014. p.2.

${ }^{128}$ Greater Wellington Regional Council, A guide to managing stock access to waterways in the Wellington Region. p.7.

${ }^{129}$ Phill Holland, 'The Dirty Dairying Campaign and the Clean Streams Accord', Lincoln Planning Review, 6(1-2), 2014 p.63.

130 Ministry for the Environment, The Dairying and Clean Streams Accord: Snapshot of Progress 2004/2005, May 2005. http://maxa.maf.govt.nz/mafnet/rural-nz/sustainable-resource-use/resource-management/dairy-clean-stream/dairyclean-stream.pdf. (accessed 06/10/2016).

${ }^{131}$ See Alan Wilde's Private collection of writings and newspaper clippings, Greytown.

\& Bunny, Milne and Keenan, River water quality and ecological health in the Ruamahanga Whaitua.

${ }^{132}$ Alan Wilde's private collection of writings and newspaper clippings, Greytown.

\& Daniel Oscar Hunter \& James Muir (Directors), River Dog, 2010 Documentary, 25.09mins.
} 
not have an adverse effect on the environment. ${ }^{133}$ Such a clause is somewhat oxymoronic within current societal and scientific discourses pertaining to stock access to water.

Allan Wilde identified that due to the immense cultural and political capital that farmers hold in the region, many residents 'who would dearly like to report pollution dare not for fear of losing their jobs. If you are a shearer, fencer, or haulage contractor, you are not going to mention any pollution you see on farms for fear of losing future work. ${ }^{134}$ While sixty percent of respondents to a 2014 Horizon research survey believed that law should enforce dairy regulations, farm managers and owners were in general disagreement with this. ${ }^{135}$ Wairarapa farmer John Coveney said that the implementation of harsh controls was likely to have unexpected outcomes. He pointed to the 'old family farming days' when family farmers discharged their effluent into streams and gullies; ${ }^{136}$ thus, one of the greatest obstacles to agricultural legislation is the perception that it poses a challenge to traditional notions of 'good farming'. 137

Raymond Leslie Buell has stated 'the success of all environmentalist efforts finally hinges not on some new technology or arcane new science, but on a state of mind: on attitudes, feelings, images, narratives. ${ }^{138}$ Market demands for food safety and environmental sustainability have increasingly challenged the cultural capital afforded to productivist farming. ${ }^{139}$ Yet adherence to market driven audit regulations is not synonymous with the development of 'green' or 'sustainable' subjectivities. ${ }^{140}$ Research by ARGOS has suggested that products marketed as 'green' or 'sustainable' are done so because they have met a certain set of audit criteria, not because the values of the producer mirror those of the consumer. ${ }^{141}$ The 'breadth of view' theory suggests that the propensity of farmers to truly ascribe to 'sustainable' and 'green' values may be affected by

\footnotetext{
133 New Zealand Government, '14.1', The Resource Management Act, Parliamentary Counsel Office, 1991. http://www.legislation.govt.nz/act/public/1991/0069/latest/DLM231973.html?search=sw 096be8ed813724b1 water 25 se\&p=1. (accessed 06/10/2016).

${ }^{134}$ Alan Wilde, 'What would you do?' Submission to the Wairarapa Times, Alan Wilde's private collection of writings and newspaper clippings, Greytown.

135 Horizon Research, Farming and the Environment. p.16.

136 Don Farmer, 'Local bodies urged to keep backyard clean', Wairarapa Times Age, 13/09/2008 in Alan Wilde's private collection of writings and newspaper clippings, Greytown.

137 Smith and Montgomery, 'Revolution or Evolution? New Zealand agriculture since 1984'. p.115.

138 Lesley M. Hunt, John. R. Fairweather, Chris.J. Rosin, Hugh Campbell, Dave Lucock. Gen Greer, 'Doing the Unthinkable: Linking farmers' breadth of view and adaptive propensity to achievement of social, environmental and economic outcomes', Conference paper, 18th International Farm Management Congress Methven, Canterbury Conference proceedings, New Zealand, 2011. p.197.

${ }^{139}$ Haggerty, Campbell and Morris, 'Keeping the stress of the sheep? Agricultural intensification, neoliberalism and 'good' farming in New Zealand'. p.767.

140 ibid. p.769.

${ }^{141}$ Campbell, Rosin, Hunt and Fairweather, 'The social practice of sustainable agriculture under audit discipline: Initial insights from the ARGOS project in New Zealand'. p.130.
} 
pressure from consumers and other external parties, but that it fundamentally lies in the habitus of individual farmers. ${ }^{142}$

The variation of farmer subjectivities within the South Wairarapa is evidence of the extent to which habitus is a fundamental mark of distinction between individuals operating at a similar frequency within social space. Pirinoa farmer Grant Muir admitted that like many farmers in the region he used to use the Ruamāhanga River for watering, shading and cooling his cattle. When he realised the adverse effects that this was having on the environment that was dear to him, he changed his farming practices. ${ }^{143}$ Yet the lobbying of people like Muir and the continued consumer demands based around similar values have had little influence on other farmers in the region. Muir attributes this to the traditional notion of agricultural cultural capital, where higher productivity and returns equates to higher societal status. For many farmers more land is synonymous with more power, they can put their stock in the river and there is nothing he can do about it. ${ }^{144}$

Fencing off paddocks and providing bridges and culverts at stock crossing points would remove the ability of stock to physically defecate into waterways. While such measures may seem obvious, the cost and time required to implement such fixtures has deterred farmers. Greytown farmer James Bruce said of his decision to graze his cattle alongside the river: he would have the area fenced off by the end of 2012, but 'fencing is a massive job, we're just starting out and we have more productive things to do.' ${ }^{145}$ Again, there is a discord between the economic and socio-environmental responsibilities of farm management. Implementation of stock management policies is a question of subjective value, but it is also often a question of objective obstacles for farmers.

A more difficult task for farmers and the councils alike is targeting nonpoint source pollution, or agricultural runoff. ${ }^{146}$ Riparian planting and sediment traps may prevent some agricultural runoff from entering water bodies, but again this is at an added cost and at the responsibility of individual farmers. ${ }^{147}$ Such measures will not cease the discharge of agricultural runoff entirely. It is within such a rubric that Hardin's theory of the Tragedy of the Commons may be re-visited. The continuing reliance of New Zealand Governments upon agriculture for economic growth determines that stock

\footnotetext{
142 Hunt, Fairweather, Rosin, Campbell, Lucock and Greer, 'Doing the Unthinkable: Linking farmers' breadth of view and adaptive propensity to achievement of social, environmental and economic outcomes.' p.201.

143 Daniel Oscar Hunter and James Muir (directors), River Dog.

144 ibid.

${ }^{145}$ Gerald Ford, 'Fouling cows draw ire', Wairarapa Times Age, 17/11/2011 in Alan Wilde's private collection of writings and newspaper clippings, Greytown.

146 'ibid'.

${ }^{147}$ Greater Wellington Regional Council, A guide to managing stock access to waterways in the Wellington Region. pp.15-17.
} 
pollution of water will continue. ${ }^{148}$ Former DOC conservancy planner Greg Carlyon stated 'It's only taken fifteen years of dairying to put at risk an international reputation and belief in ourselves that we run a pretty good ship around the environment....moves so far are welcome. But what they're about is trying to reconcile whether we can have our cake and eat it too-protect and sustain the environment, and grow the economy. ${ }^{149}$ The question of what is valued increasingly pertains to not to farmer subjectivities, but to national politics.

South Wairarapa bed and breakfast owner Pauline McLeod lamented 'Dirty riverbanks fly in the face of New Zealand's $100 \%$ pure image.' 150 Tourism is one of New Zealand's most significant sources of foreign exchange and a major growth industry in New Zealand. ${ }^{151}$ Nevertheless, as Green Party coleader Russel Norman contended in 2011, 'healthy rivers are essential for a healthy economy as our clean, green brand underpins tourism and agricultural exports. ${ }^{152}$ The poor state of New Zealand freshwater ecology and the multifaceted political, social and economic reasons behind it highlight the opaqueness of New Zealand's 'Clean Green' image. This is particularly relevant in the South Wairarapa where Peter Howland has shown that tourists are drawn to the region not only by 'a vineyard experience', but also by romanticised notions of rural life. ${ }^{153}$

According to scientists New Zealand's 'green' reputation is a long running farce yet 'Clean, Green New Zealand' continues to be the country's national brand. This greenwashing has continued to be successful for several reasons. The first concerns the clever marketing of agricultural exports as 'quality marked', 'free range' or 'eco-friendly'. As aforementioned, these labels need not be representative of farmer subjectivities but evidence the meeting of particular audit criteria. There is no correlation between the meeting of these criteria and farm management practices that are not measured; ${ }^{154}$ products marketed as 'environmentally friendly' can often have adverse effects on the environment throughout their eco-commodity chain. Secondly, New Zealand's tourism sector

\footnotetext{
148 Hansford, 'Water Liquidation'. p.38.

149 Jon Morgan, 'River Health waits on Brave Leaders' and 'Manager moving on from Horizons role', The Dominion Post, 20/11/2011 in Alan Wilde's private collection of writings and newspaper clippings, Greytown.

150 Don Farmer, 'Fence keeping river clean' and 'One live wire is all it takes', Wairarapa Times-Age, Thursday 15/12/2011 in Alan Wilde's Private collection of writings and newspaper clippings, Greytown.

151 The Treasury, 'Service Industries', New Zealand Economic and Financial Overview 2012, Industrial Structure and Principal Economic Sectors. p.24 http://www.treasury.govt.nz/economy/overview/2012/nzefo-12.pdf. (accessed 06/10/2016.)

152 Annie Hickland, 'Rivers cleaner but job's not done', Wairarapa Times Age, 24/10/2011 in Alan Wilde's Private collection of writings and newspaper clippings, Greytown.

153 Howland, 'Martinborough's Wine Tourists and the Metro-Rural Idyll'. p.77.

${ }^{154}$ Campbell, Rosin, Hunt and Fairweather, 'The social practice of sustainable agriculture under audit discipline: Initial insights from the ARGOS project in New Zealand'. p.132.
} 
utilises humanity's fixation with the wonders of nature. ${ }^{155}$ By drawing attention to New Zealand's 'rugged coastlines', 'snow-capped alps' and 'scenic national parks', the industry draws attention to aspects of the environment that are either artificially protected from the adverse effects of production, or in which these effects are concealed. However, a growing international awareness of the state of the New Zealand environment increasingly threatens this. In 2010, New Zealand ranked 18th worst out of 189 nations in an independent study examining a range of environmental criteria, from water quality to loss of native vegetation. ${ }^{156}$ This report was subsequently published in the New York Times in 2012. ${ }^{157}$

\section{A productive industry?}

There have been a significant number of perceptive and physical changes to both the South Wairarapa environment and its agricultural sector over the past thirty years. These primarily concern production relations, the resources used in production and the subjective values attached to relations of production and natural resources. Some short term consequences of neoliberal reform, such as economic and social restructuring necessitated by the removal of subsidies, are observable. Yet when situated within a longer historical trajectory, there is a link between environmental change in the region and the predominance of an agricultural productivist culture. This culture pre-dates neoliberal restructuring, and in many ways re-structuring may be seen as a consequence of this culture, not vice-versa.

Throughout the history of the South Wairarapa farmers have possessed yo-yoing levels of political and economic capital. The Long Boom, and the Muldoon years in particular, represent periods in history where farmers held significant political and economic capital within the context of the South Wairarapa. The harsh conditions of neoliberal reforms were an affront to this. However, the continuation of agriculture as the region's primary industry lies in the strength of the cultural capital attached to farming. The South Wairarapa has been an agricultural society and local economy since European settlement in the nineteenth century. An abandonment of this heritage during an economic downturn would have crumbled the foundations of communities further. For this reason,

\footnotetext{
155 William Cronon (ed.), Uncommon Ground; Rethinking the Human Place in Nature, W.W Norton, New York, 1995. p.88.

${ }^{156}$ Corey. J.A. Bradshaw, Xingli Giam, Navjot. S. Sodhi, 'Evaluating the Relative Environmental Impact of Countries', PLoS One, 5/5, May 2010. p.2

http://journals.plos.org/plosone/article?id=10.1371/journal. pone.0010440\#pone-0010440-t004. (accessed 07/10/2016.)

${ }^{157}$ Charles Anderson, 'New Zealand's Green Tourism Push Clashes with Realities', New York Times, November 16th 2012. http://www.nytimes.com/2012/11/17/business/global/new-zealands-green-tourism-push-clashes-withrealities.html. (accessed 07/10/2016).
} 
farming retained its cultural capital throughout the 1980 s and 1990s. It is also likely that for this reason many pre-1984 concepts and cultures surrounding notions of what constituted 'good' farming practice remained the status quo.

As farmers again have begun to accrue political and economic capital within the South Wairarapa social space, rivalries and contests have begun to occur. It is scientifically and environmentally minded subjectivities that pose the most significant challenge to the political capital enjoyed by farmers. ${ }^{158}$ There have been calls for farmers to re-align cultural concepts of 'good farming' with more environmentally conscientious practices. However, the 'breadth of view' theory suggests that changes in farm management practices are dependent upon a change in the subjectivities of farmers themselves.

The persistence of agricultural productivist culture among New Zealand farmers is evident across economic, social and environmental change. There is a significant degree of synonymy between this culture and the intensification of farming. There is no causal link between neoliberal reform and intensification. ${ }^{159}$ Because nature is in and of itself a historical actor, changing relations between humans and nature however determined will have ramifications that will in turn determine new outcomes. The change from pastoral intensification to dairy and cattle intensification is a prime example of this. The culture of agricultural productivism has remained unchanged, but economic imperatives and necessities have changed the nature of what is being produced. This has had a profound environmental, political and social effect because cattle and sheep require different farm management strategies and interact with natural resources in different ways. Current voices within the South Wairarapa community and the nation as a whole are now contesting the environmental viability of dairy farming and the nature of what sustainability means.

\footnotetext{
158 Bourdieu, Practical Reason. p.17.

${ }^{159}$ Haggerty, Campbell and Morris, 'Keeping the stress of the sheep? Agricultural intensification, neoliberalism and 'good' farming in New Zealand'. p.776.
} 


\section{Chapter 2: Viticulture}

\section{'Farming was shot, we had to diversify'}

Changes to land use in the South Wairarapa stretched beyond the diversification of agricultural industries with the development of the Martinborough boutique wine industry. Nelson Clark, formerly of Bluerock vineyard said of his decision to dedicate six hectares of his farmland to grapevines, 'farming was shot, so we had to diversify.'

The story of how the struggling rural town of Martinborough became a 'wine village that's truly on the world map for its brilliant pinot noir' is a fascinating one, shaped by the environmental, social and economic context of its origins and of the past thirty years. ${ }^{3}$ The contrast with the late 1970s, when the township 'appeared to be sliding off the map' due to its distance from the mainline railway is notable. ${ }^{4}$ Peter Howland has recently ascribed the town the status of a 'metro-rural idyll'; a rural village, which functions as a performative site of middle class distinction through the consumption of expensive, high quality wines and produce, and idealised notions of rural life. ${ }^{5}$

Although the New Zealand wine industry only began to gain momentum in the 1960s and 1970s, New Zealand's first bottled wine predates the signing of the Treaty of Waitangi. ${ }^{6}$ However, the environmental and cultural context of the nineteenth century was not ripe for winemaking; vines were vulnerable to disease, and wine was seen as a drink for the elite by the primarily working class, beer drinking settler demographic. ${ }^{7}$ The temperance movement and increasingly restrictive liquor licensing further retarded the growth of the industry at the turn of the century. ${ }^{8}$ Despite this, William Beetham returned from a trip to France in 1894 and began to plant vines in the garden of his Masterton townhouse, perhaps in an unconscious embrace of the comparable 'terroirs' of the two parts of the world. ${ }^{9}$

\footnotetext{
${ }^{1}$ Nelson Clark, former farmer and owner of Bluerock Vineyard in Michael Cooper, The Vines and Vineyards of New Zealand, 4th edition, Hodder and Stoughton, Auckland, 1993. p.131.

${ }^{2}$ Cooper, The Wines and Vineyards of New Zealand. p.131.

3 'Home page', http://www.martinborough.com. (accessed 09/05/2017).

${ }^{4}$ Mclntyre, Canoes of Kupe. p.252.

${ }^{5}$ Howland, 'Martinborough's Wine Tourists and the Metro-Rural Idyll', Journal of New Zealand Studies, Issue 6, 2008. p.78.

${ }^{6}$ Michael Cooper, Wine Atlas of New Zealand, 2nd edition, Hodder Moa, Auckland, 2008. p.8.

7 ibid. p.9.

8 ibid.

${ }^{9}$ McIntyre, Canoes of Kupe. p.253.
} 
However, in 1908 the Masterton electorate voted itself dry, abruptly putting a stop to any prospect of a commercial Beetham vineyard or any other viticulture venture in Masterton until the restoration of liquor licences in $1946 .{ }^{10}$ Elsewhere in the country production had continued, winemakers who had endured the social and economic hardships of the past twenty years had an upturn of luck in the early twentieth century. ${ }^{11}$ The newly developed post of Government Viticulturist marked the beginning a scientific foray against vine diseases such as phylloxera and oidium. ${ }^{12}$ The domestic market for wine developed gradually over the 1920s and 30s, booming during war time when the Government raised duties on overseas wine imports. ${ }^{13}$ It would appear that settlers' palates had begun to adapt to the vitis vinifera.

Now that wine had won over New Zealanders a problem presented itself for viticulturists in the form of foreign competition; the easing of import restrictions following World War II placed the wines of small-scale domestic growers in direct competition with cheap Australian and European imports. ${ }^{14}$ Despite the reinstatement of liquor licences to Masterton, the economic conditions for beginning a vineyard were very different from how they had been only twenty years previously. ${ }^{15}$

Elsewhere in the country a number of viticulture and winemaking associations were formed, which would successfully lobby the Government for legislative concessions throughout the 1950s and 1960s. ${ }^{16}$ Viticulturists accrued a significant amount of cultural and political capital through the launching of the Annual Dinner and Field Day for Parliamentarians in 1952. ${ }^{17}$ The Second Labour Government cut the imports of wines and spirits and hiked up taxation on beer and spirits in the 'Black Budget' of 1958. ${ }^{18}$ Muldoon, too, was a noted advocate of the New Zealand wine industry in the 1960 s and 1970 s.

The political favour of viticulture in the late 1950s had the effect of creating 'an immediate and unprecedented demand for New Zealand wines. The market position for New Zealand wines changed from one of difficult and competitive trading to a buoyant market supply. ${ }^{19}$ It was under

\footnotetext{
${ }^{10}$ Ministry for Culture and Heritage, 'Masterton under no-license', updated 30-Jun-2014.

https://nzhistory.govt.nz/politics/temperance-movement/masterton-under-no-license. (accessed 09/05/2017).

${ }^{11}$ Cooper, Wine Atlas of New Zealand. p.12.

12 ibid.

13 ibid. p.8.

${ }^{14}$ ibid.

15 ibid. p.13

16 ibid.

17 ibid. p.14.

18 ibid. p.15.

${ }^{19}$ Department of Agriculture and Fisheries, Annual Report, Wellington, 1959.
} 
these political and economic conditions that the modern pioneer of the Martinborough viticulture industry, Alastair Taylor, planted his first vines on the banks of the Huangarua River in 1977.

Taylor selected his land on the eastern banks of the Huangarua River based on a comparison between the climate and topography of Martinborough, and the successful Marlborough wine growing area the Wairau Valley. ${ }^{20}$ Geographically the dry, flat Martinborough Plains-surrounded on either side by the Ruamāhanga and Huangarua Rivers, also resembled the flat plains of the Wairau Valley, framed by the Wairau and Waihopai Rivers. Both regions have areas of alluvial limestone gravels, covered by silty loess carried from the coast. ${ }^{21}$ These soils which drain well and are of moderate fertility are regarded as ideal for the production of high-end wines. ${ }^{22}$ Wine historian Michael Cooper notes that New Zealand's wine growing regions can fit into three climatic subsections. The Wairarapa, Nelson and Marlborough all reside within the Central Zone, which is cooler than Northland and the Hawkes Bay (the Northern Zone), but has the highest sunshine hours in the country. ${ }^{23}$ Cooper also adds that temperature is the most important climatic condition for viticulture, as stages of a plant's development are dependent upon certain weather conditions. ${ }^{24}$

Taylor's vines had been planted too close to the banks of the Huangarua River. The high water table led to over fertile soils which damaged the quality of the grapes and led to rot and botrytis. ${ }^{25}$ Taylor's failings did not deter later winemakers; his venture 'sparked the interest of a few others. ${ }^{26}$ In 1979 Neil McCallum and his accountant John Mead bought the land that would become Dry River Vineyard outright. The land was subdivided and converted from a sheep station into a vineyard. ${ }^{27}$ All of the pioneering Martinborough Winemakers interviewed by Heather Cormack in her 1990

\footnotetext{
${ }^{20}$ Mclntyre, Canoes of Kupe. p. 256.

${ }^{21}$ J.D.Cowie \& J.D.G Milne, General Suitability of the Wairarapa Plains for Cropping, Report WN1, Soil Bureau District Office, Department of Scientific and Industrial Research, New Zealand, 1980. p.2.

\& H.S. Gibbs \& C.G. Vucetich, Soils of Marlborough, Soil Bureau, Department of Scientific and Industrial Research. www.grassland.org.nz/publications/nzgrassland publication 1782.pd. (accessed 11/07/2016). p.8.

${ }^{22}$ Mark. L. Chein, 'Soil and Site Selection Considerations for Wine Grape Vineyards', College of Agricultural Sciences Cooperative Extension, Penn State University, 2009.

http://www.pawinegrape.com/uploads/PDF\%20files/Documents/Viticulture/Site\%20Selection\%20for\%20Wine\%20Vi neyards Chien.pdf. (accessed 11/07/2016.)

${ }^{23}$ Cooper, Wine Atlas of New Zealand. p.27

*Coopers' theory is adapted from a geography thesis, see also; Chad Douglas, 'Latitudinal Limit of Commercial Viticulture in New Zealand', MSc thesis, University of Otago, 2000.

24 ibid.

${ }^{25}$ Cooper, The Wines and Vineyards of New Zealand. p.126.

${ }^{26}$ Heather Cormack, Martinborough Winemakers Oral History Project; Tom Draper, Tape 1, Side 1, Martinborough, 27/08/1990. Wairarapa District Archive, record no. OHA513.

27 ibid.
} 
Martinborough Winemakers Oral History Project entered the commercial wine business through financial partnerships as McCallum did, purchasing farm land and converting it into vineyards. ${ }^{28}$

The decline of New Zealand's traditional pastoral economy does little to explain why viticulture became the predominant industry in Martinborough. The reasons are themselves multi-faceted and contested. Historians of the New Zealand wine industry have tended to emphasise the importance of Italian viticulture advisor, Romeo Bragato's 1895 Report on the Prospects of Viticulture in New Zealand which dedicates a little over a page-of twenty-to the suitability of the Wairarapa region for viticulture. ${ }^{29}$ Bragato's report focusses on the Masterton Region. The Martinborough Region is topographically and climatically quite different from Masterton. Furthermore, the report, published almost a century before the commercial wine industry in Martinborough began to develop, is unlikely to have been particularly influential for pioneer Martinborough winemakers.

Micro-historical work conducted by scholars such as Heather Cormack and Peter Howland allows for a more in depth understanding of the development of the Martinborough industry in particular. The eight pioneering Martinborough winemakers interviewed by Cormack overwhelmingly stated that what drew them to Martinborough was its climatic and geographic similarities to other national and international winegrowing areas, particularly the Marlborough Region in New Zealand and the Burgundy Region in France. ${ }^{30}$ This encompassed an understanding of the French concept of terroir, which embraced all the physical, ecological and human factors that influence wine style. ${ }^{31}$ Although Michael Cooper attributes the popularity of the concept of terroir to the 1990s, the pioneering Martinborough winemakers were adhering to it, whether consciously or not in the late 1970s and 1980s. ${ }^{32}$

For the most part Cormack's interviewees stressed that they were viticultural novices and that they had no knowledge of the suitability of Martinborough to viticulture. ${ }^{33}$ Yet, important factors relating to scientific knowledge, corporate economics and class underlay both the drive to develop the wine industry and the development of the region from that point on. Historians have suggested that the economic reforms of the 1980s, a subsequent push for diversification and the difficulties faced by

\footnotetext{
${ }^{28}$ Heather Cormack, Martinborough Winemakers Oral History Project, 1990-91, Wairarapa District Archive, record no. 505131.

${ }^{29}$ Romeo Bragato, Report for the Prospects of Viticulture in New Zealand; Together with Instructions for Planting and Pruning, New Zealand Department of Agriculture, Wellington, 1895.

${ }^{30}$ Cormack, Martinborough Winemakers Oral History Project.

${ }^{31}$ Cooper, Wine Atlas of New Zealand. p.6.

32 ibid.

${ }^{33}$ Phyllis Paton, Tom Draper, Neil McCallum and others in Cormack, Martinborough Winemakers Oral History Project.
} 
farmers, were drivers for the establishment of the viticulture industry across New Zealand. Little research addresses the historical trajectory of New Zealand's viticulture industry and the relative uniqueness of the political and economic situation that viticulture had been enjoying since the mid1950s. While the reforms of the Fourth Labour Government may have had some short-term effects on the industry, it is the Second Labour Government to which the exponential growth of the viticulture industry is logically attributable.

There is a necessity to examine how important scientific information was to pioneering Martinborough winemakers. There is little historiographical acknowledgement of how land use changed in accordance with the science of the wine industry. What to plant, how to plant and how to deal with existing environmental challenges are all important facets of how winemaking reshaped the Martinborough Region, and how in turn Martinborough shaped the wine-industry.

The corporate side of wine is well covered in the press, the prices of wine, value of shares and sales of vineyards all being accessible figures. The private side of the corporate market, the economic trials, triumphs and decisions of vineyard owners and winemakers themselves, are largely unacknowledged. Cooper and other wine historians have addressed how the exclusivity of boutique wines helped Martinborough to develop as a winemaking region. ${ }^{34}$ The small scale, top end focussed nature of the Martinborough wine industry protected it from the wine glut of the 1980 s. ${ }^{35}$ Yet, few scholars have addressed how these boutique wines function on the market today in comparison to cheaper alternatives from more commercially driven ventures. There is a question of whether the intertwining of ideologies of sustainability and exclusivity continue to be economically viable as the industry has developed into the twenty-first century.

Directly linked to the image of exclusivity is the emergence of Martinborough as a 'boutique wine village' and the development of a lucrative tourist trade. This transformation is well documented and perpetuated through popular media such as magazines, newspapers and tourist information sites. Cultural anthropologist Peter Howland has extensively examined the habitus of upper-middle class wine tourism within the region. ${ }^{36}$ However, there has been no cohesive study of the social and cultural impact of the wine industry upon the resident Martinborough population. As Brooking and

\footnotetext{
${ }^{34}$ See Cooper, The Vines and Vineyards of New Zealand.

\& Cooper, Wine Atlas of New Zealand.

${ }^{35}$ Cooper, The Wines and Vineyards of New Zealand. p.20.

${ }^{36}$ See Howland, 'Martinborough's Wine Tourists and the Metro-Rural Idyll'.

\& Peter Howland, 'Euro-chic, Benign Cosmopolitanism and Wine Tourism in Martinborough, New Zealand', From

Production to Consumption; Transformation of Rural Communities, Hana Horakova and Andrea Boscoboinik (eds.), Lit Verlag, Berlin, 2012. pp. 113-129.
} 
Pawson argue, the environments that people inhabit are inextricable from human culture and initiative. ${ }^{37}$ This chapter will address the intertwining environmental, economic and class factors that underlay, and shaped the development of the Martinborough wine industry.

\section{From terrain to terroir}

Soil and climate statistics from the Martinborough Region and Wairau Region support Alastair Taylor's 1977 assumptions and suggest that the failure of his venture was not due to the unsuitability of the land for viticulture. ${ }^{38}$ The regions had similar maximum and minimum average temperatures between 1982 and 2012, with maximum rainfall occurring during the winter months and minimum rainfall occurring during the ripening and harvesting season. ${ }^{39}$ Although Taylor's initial attempt was unsuccessful, Cormack's interviews suggest that he lay down the roots of what was to become a sprawling new industry for the small rural township.

The other acknowledged reason for the surge of interest in Martinborough wine making was Derek Milne's 1979 DSIR report on the soil topography of Martinborough. ${ }^{40}$ Milne's conclusion that the region's climate and topography resembled that of the French winemaking region of Burgundy, famed for its pinot noirs and chardonnays, was profoundly important. Unlike Taylor, Milne had experienced the systematic plotting of soil and climate conditions across Europe. Analysis revealed that the soil topography of Martinborough was not homogeneously suited to viticulture; land to the southeast of the region was disturbed by a clay rich silt pan which was impenetrable to roots and had poor water absorption, ${ }^{41}$ further south, the fertile silt loams around Lake Wairarapa and Lake Ferry were also unsuitable for wine growing. ${ }^{42}$ Milne presented his findings at a meeting for Horticultural Development in Martinborough on 29 September 1979. ${ }^{43}$

The Martinborough wine industry and many scholars have stressed the significance of Milne's Martinborough-Burgundy comparison, yet Milne claims that he made little reference to grapes in

\footnotetext{
${ }^{37}$ Brooking and Pawson, Making a new land. p.19.

38 See Figure 1.

${ }^{39}$ Temperature and Rainfall statistics for Martinborough, Wairarapa found at 'Climate: Martinborough', ClimateData.org, http://en.climate-data.org/location/32426/. (accessed 12/07/2016). and Temperature and Rainfall statistics for Wairau Valley found at 'Climate: Wairau Valley', Climate-Data.org, http://en.climate-data.org/location/764990/. (accessed 12/07/2016).

${ }^{40}$ See Cooper, The Wines and Vineyards of New Zealand. p.126.

Howland, 'Martinborough's Wine Tourists and the Metro-Rural Idyll'. p.119

\& Cormack, Martinborough Winemakers Oral History Project. Among others.

${ }^{41}$ Cormack, Martinborough Winemakers Association Oral History Project; Derek Milne, Tape 2, Side 1, Greytown, 16/09/1990. Wairarapa District Archive, OHA521.

${ }^{42}$ Cooper, The Wines and Vineyards of New Zealand. p.127.

${ }^{43}$ Mclntyre, Canoes of Kupe. p.253.
} 
his presentation. ${ }^{44}$ Here we can see both a historiographical and industry overlap between environmental factors and socioeconomic factors. Comparison to the renowned region of Burgundy has served the Martinborough wine industry well. The comparison may even have led to the predominance of pinot noir and chardonnay associated with Martinborough. ${ }^{45}$ Yet as figure one shows, the terroir of Martinborough is arguably no more similar to Burgundy than it is to the Wairau Valley.

\footnotetext{
${ }^{44}$ Cormack, Martinborough Winemakers Association Oral History Project; Derek Milne, Tape 2, Side 1, Greytown, 16/09/1990.

${ }^{45}$ Cooper, Wine Atlas of New Zealand. pp.220-221.
} 
Fig. 1 Burgundian, Wairau and Martinborough Terroir

\begin{tabular}{|c|c|c|c|c|c|}
\hline Region & $\begin{array}{l}\text { Max. } \\
\text { Temp }\end{array}$ & $\begin{array}{l}\text { Min. } \\
\text { Temp }\end{array}$ & Max. rainfall & $\begin{array}{l}\text { Min. } \\
\text { rainfall }\end{array}$ & Soil type \\
\hline Dijon, Burgundy ${ }^{46}$ & $\begin{array}{l}19.3^{\circ} \mathrm{C} \\
\text { July }\end{array}$ & $\begin{array}{l}1.4^{\circ} \mathrm{C} \\
\text { January }\end{array}$ & $\begin{array}{l}77 \mathrm{~mm}, \\
\text { May }\end{array}$ & $\begin{array}{l}51 \mathrm{~mm}, \\
\text { March }\end{array}$ & 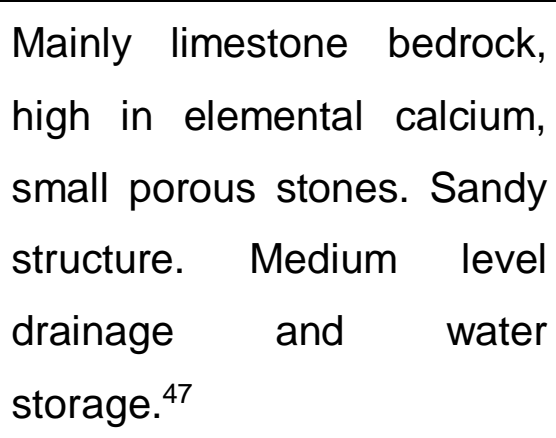 \\
\hline Martinborough ${ }^{48}$ & $\begin{array}{l}17.6^{\circ} \mathrm{C} \\
\text { January }\end{array}$ & $\begin{array}{l}8.4^{\circ} \mathrm{C} \text {, } \\
\text { July }\end{array}$ & $\begin{array}{l}97 \mathrm{~mm}, \\
\text { July }\end{array}$ & $\begin{array}{l}41 \mathrm{~mm}, \\
\text { Feb }\end{array}$ & $\begin{array}{l}\text { Moderately deep silty soils } \\
\text { over alluvial gravels. Variable } \\
\text { in terms of depths to gravel } \\
\text { and drainage. }{ }^{49}\end{array}$ \\
\hline Wairau Valley ${ }^{50}$ & $\begin{array}{l}16.9^{\circ} \mathrm{C} \\
\text { January }\end{array}$ & $\begin{array}{l}6.7^{\circ} \mathrm{C} \text {, } \\
\text { July }\end{array}$ & $\begin{array}{l}117 \mathrm{~mm}, \\
\text { August }\end{array}$ & $\begin{array}{l}59 \mathrm{~mm}, \\
\text { Feb }\end{array}$ & $\begin{array}{l}\text { Alluvial limestone with } \\
\text { medium level drainage and } \\
\text { water storage on the south } \\
\text { side of the valley. Plains, } \\
\text { loess over light gravelly } \\
\text { alluvium. Rapid drainage with } \\
\text { irrigation required. }{ }^{51}\end{array}$ \\
\hline
\end{tabular}

\footnotetext{
${ }^{46}$ Temperature and Rainfall statistics for Dijon, Burgundy found at 'Climate: Burgundy', Climate-Data.org. http://en.climate-data.org/region/312/. (accessed 12/07/2016).

${ }^{47}$ Chein, 'Soil and Site Selection Considerations for Wine Grape Vineyards'.

http://www.pawinegrape.com/uploads/PDF\%20files/Documents/Viticulture/Site\%20Selection\%20for\%20Wine\%20Vi neyards Chien.pdf. (accessed 11/07/2016.) p.37.

${ }^{48}$ Temperature and Rainfall statistics for Martinborough, Wairarapa found at 'Climate: Martinborough', ClimateData.org, http://en.climate-data.org/location/32426/. (accessed 12/07/2016).

${ }^{49}$ Cowie and Milne, General Suitability of the Wairarapa Plains for Cropping. p.2.

${ }^{50}$ Temperature and Rainfall statistics for Wairau Valley found at 'Climate: Wairau Valley', Climate-Data.org, http://en.climate-data.org/location/764990/. (accessed 12/07/2016).

${ }^{51}$ Gibbs and Vucetich, Soils of Marlborough. p.8.
} 
Peter Howland has discussed how comparison between the Martinborough and Burgundy winegrowing regions enabled perceptions of grandeur attributed to the latter to gradually pertain to the former. ${ }^{52}$ This finding suggests that the ideology of 'Euro-chic' predated the development of tourism in the region, and was in fact a driver of the wine industry itself. ${ }^{53}$ Comparison of the Martinborough topography with that of Burgundy suggested that viticulture would be successful and drew viticulturists to the area. ${ }^{54}$ It appears to have influenced the varieties of grapes grown in the region, the methods utilised by viticulturists and winemakers and more recently, the development of the town itself.

\section{Fig. $2^{55}$}

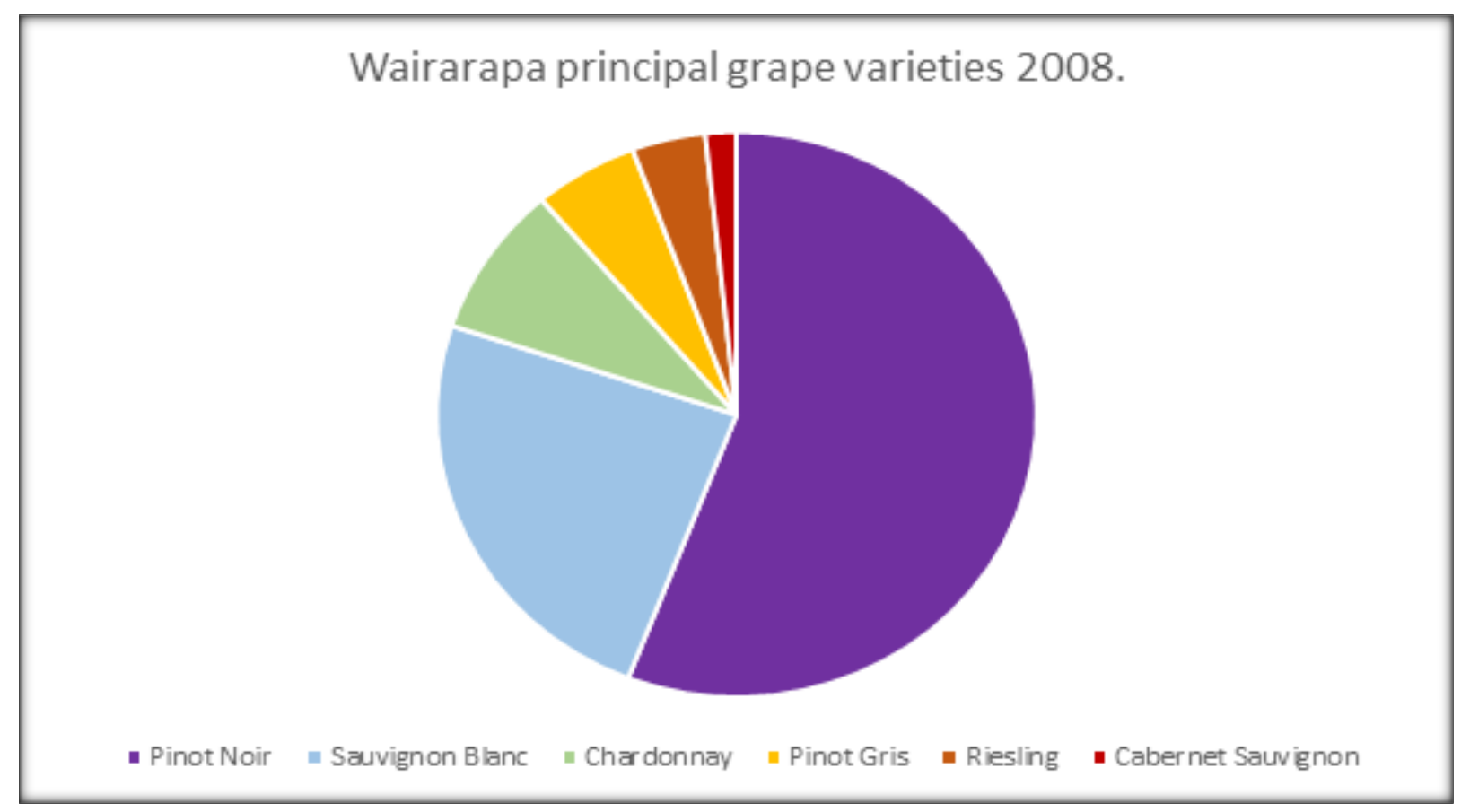

The Martinborough Region is famed for its prize winning pinot noir, further promoting comparison with Burgundy. Statistics show that 500 of a planted 924 hectares of vines in the Wairarapa Region are of the pinot noir variety. ${ }^{56}$ Yet, there is little record as to why pinot noir plantings came to dominate the Martinborough Region. Cormack's interviews reveal that the pioneering viticulturists

\footnotetext{
52 See, Peter Howland, Metro-rurality, social distinction \& ideal reflexive individuality: Martinborough's Wine Tourists, Anthropology PHD thesis, University of Canterbury, 2008.

${ }^{53}$ Howland, 'Euro-chic, Benign Cosmopolitanism and Wine Tourism in Martinborough, New Zealand'. pp. 113-129.

${ }^{54}$ Cooper, The Wines and Vineyards of New Zealand. p.126.

55 'Regions: Wairarapa', New Zealand Wine, http://www.nzwine.com/regions/wairarapa/. (accessed 13/07/2016).

${ }^{56}$ See fig.2. 'Regions: Wairarapa', New Zealand Wine, http://www.nzwine.com/regions/wairarapa/. (accessed 13/07/2016).
} 
at Martinborough, Dry River, Chifney and Ata Rangi vineyards were indiscriminate about the varieties of cuttings that they planted. ${ }^{57}$

Through trial and error viticulturists discovered that the cool climate and alluvial limestone soils of Martinborough were well suited to grapes of the pinot noir variety. Stan Chifney told Heather Cormack 'I don't think any of us really knew what to plant in 1980. We knew what we'd like to plant, but we hedged our bets. ${ }^{58}$ According to Romeo Bragato's report pinot noir vines were a challenge to viticulturists; they were early budding, prone to spring frosts and susceptible to rot. ${ }^{59}$ Neil McCallum recalls that he decided to avoid planting chardonnay based on a poor performance of vines in other vineyards despite its reputation as a versatile plant that grows in most parts of the world. ${ }^{60}$

Viticulturists continued to persist with pinot noir, putting Martinborough on the medal tables between 1985 and $1990 .{ }^{61}$ Whether the early success of pinot noir was due to a deliberate attempt to promote the region as 'a Burgundian one', or a general suitability of the grape to the region remains unclear; ${ }^{62}$ yet pinot noir's popularity and success has continued to this day.

\footnotetext{
${ }^{57}$ Cormack, Martinborough Winemakers Oral History Project.

${ }^{58}$ Cormack, Martinborough Winemakers Oral History Project; Stan Chifney, Tape 2, Side 1, Martinborough, 14/08/1990, Wairarapa District Archive, record no. OHA490.

${ }^{59}$ Cooper, Wine Atlas of New Zealand. p.39.

${ }^{60}$ Cormack, Martinborough Winemakers Oral History Project; Neil McCallum, Tape 2, Side 1, Martinborough, 25/08/1990, Wairarapa District Archive, OHA507.

\& Michael Cooper, The Wines and Vineyards of New Zealand. p.29.

${ }^{61}$ See fig.3.

${ }^{62}$ Cormack, Martinborough Winemakers Oral History Project; Stan Chifney, Tape 3, Side 2.
} 
Fig. $3^{63}$

Air New Zealand Wine Awards medal wins for pioneer Martinborough Wineries 1986-1989

\begin{tabular}{|c|c|c|c|c|}
\hline Winery & Vintage & Medal & Variety & Winemaker \\
\hline Chifneys & 1986 & Gold-1988 & Cab-Sav & Stan Chifney \\
\hline Ata Rangi & $\begin{array}{l}1985 \\
1988 \\
1988\end{array}$ & $\begin{array}{l}\text { Gold-1986 } \\
\text { Gold-1989 } \\
\text { Gold-1990 }\end{array}$ & $\begin{array}{l}\text { Pinot Noir } \\
\text { Pinot Noir } \\
\text { Caleb }\end{array}$ & $\begin{array}{l}\text { Clive Paton } \\
\text { Clive Paton } \\
\text { Clive Paton }\end{array}$ \\
\hline Martinborough & \begin{tabular}{r|}
1986 \\
1987 \\
1988 \\
1989 \\
1986 \\
1987 \\
1988 \\
1989
\end{tabular} & $\begin{array}{l}\text { Gold-1987 } \\
\text { Gold-1988 } \\
\text { Gold-1989 } \\
\text { Gold-1990 } \\
\text { Gold-1987 } \\
\text { Gold-1988 } \\
\text { Gold-1989 } \\
\text { Gold-1990 }\end{array}$ & $\begin{array}{l}\text { Chardonnay } \\
\text { Chardonnay } \\
\text { Chardonnay } \\
\text { Chardonnay } \\
\text { Pinot Noir } \\
\text { Pinot Noir } \\
\text { Pinot Noir } \\
\text { Pinot Noir }\end{array}$ & $\begin{array}{l}\text { Russel Shorts } \\
\text { Larry McKenna } \\
\text { Larry McKenna } \\
\text { Larry McKenna } \\
\text { Russel Shorts } \\
\text { Larry McKenna } \\
\text { Larry McKenna } \\
\text { Larry McKenna }\end{array}$ \\
\hline Dry River & ------- & ------- & ------ & ----- \\
\hline
\end{tabular}

The resources at hand determined the shape of the four initial Martinborough vineyards. Phyllis Paton of Ata Rangi vineyard laughs at the extent to which her husband's former farming equipment determined the layout of his vineyard. 'The plants were planted far apart because of an old David Brown tractor that's only worth about three thousand dollars. You think now, that we're limited about what we can get off the land, we could have reaped it more times over. But when you're on a shoestring those compromises have got to be made. ${ }^{64}$ Derek Milne, who arguably knew the most about the necessary infrastructure of vineyards, also lamented that he 'wanted to have narrow spacing...but the problem was we were coming into a district with no horticultural infrastructure at

\footnotetext{
${ }^{63}$ See, Cormack, Martinborough Winemakers Oral History Project.

${ }^{64}$ Cormack, Martinborough Winemakers Oral History Project; Phyllis Paton, Tape 2, Side 1, Martinborough, 9/03/1991. Wairarapa District Archive, record no. OHA525.
} 
all. So you had tractors and tines and discs and things that were standard agricultural width. ${ }^{65}$ In the early years, Martinborough viticulturists structured their vineyards predominantly around consultation with one another, financial limitations and available equipment.

\section{What's in a name?}

As the Martinborough wine industry developed so did recognition of the wines that it produced. Appellation schemes in the Old World attributed both cultural and economic significance to the geographic region of a wines production. ${ }^{66}$ This enabled producers to gain a 'premium for quality based on provenance' by certifying the consistently high quality of a product based upon the French concept of terroir; ${ }^{67}$ physically, as we have seen, it describes the meteorological, geological and geographical qualities of a vineyard, culturally it describes the human processes of viticulture from planting and pruning techniques through to winemaking techniques. It also culturally amalgamates provenance and product, ascribing particular characteristics to wines from a certain appellation. Marketing, brand development and consistently good performances at competitions entrench a perception of higher quality for defined winegrowing regions than for geographically non-defined ones. ${ }^{68}$

One of the defining features of the New Zealand wine industry in the twentieth century was an opposition to the 'false indication of quality' attributed to the appellations of Old World wine regions such as Burgundy and Champagne. ${ }^{69}$ Small-scale producers outnumbered corporate producers in the 1980s. Yet, like the country's other land-based industries the emphasis was on economies of scale and low cost per unit production. ${ }^{70}$ Quite early on, the pioneer viticulturists of Dry River, Ata Rangi, Chifney and Martinborough Vineyards took the country's first steps toward entrenching the boutique nature of the region's industry through the development of an appellation scheme.

The Martinborough Terraces Appellation drew its geographical boundaries from the soil report of Derek Milne. ${ }^{71}$ The Gimblett Gravels Winegrowers Association formed in Hawkes Bay ten years later

\footnotetext{
${ }^{65}$ Cormack, Martinborough Winemakers Association Oral History Project; Derek Milne, Tape 2, Side 1.

${ }^{66}$ Warwick Murray and John Overton, 'Defining Regions: the making of places in the New Zealand wine industry', Australian Geographer, 42:4. p.421.

67 John Overton and Warwick Murray, 'Finding a place for New Zealand Wine; Terroir and regional denominations', in Peter Howland (ed.), Social, Cultural and Economic Impacts of Wine in New Zealand, Taylor and Francis, 16/04/2014. p.42.

68 ibid. p.42.

69 ibid. p.43.

70 ibid. p.42.

${ }^{71}$ Cormack, Martinborough Winemakers Association Oral History Project; Derek Milne, Tape 1, Side 2.
} 
was to mimic this process, defined by the Master of Wine thesis of then soil scientist Steve Smith (later head winemaker at Craggy Range vineyard and chair of the New Zealand Winemakers Association). ${ }^{72}$ The Martinborough Terraces Appellation was initially a five-kilometre radius, suited to cool-climate grape varieties, determined by its low rainfall and deep, free-draining gravels. ${ }^{73}$ Both the Martinborough and Hawkes Bay Appellations served as a guarantee that wines from these regions would be of consistently high quality and show similarities reflecting their origin. ${ }^{74}$ Yet, while the Gimblett Gravels Appellation became legally entrenched through a trademark the Martinborough Terraces Appellation had no such legal protection and was subsequently compromised by the growth of viticulture in the region.

Clive Paton maintained in 1990 that the intention had always been, 'to extend the area out beyond the original appellation. ${ }^{75}$ As the decade unfolded and the viticulture industry in the region boomed, the Martinborough Winemakers Association (MWA) had little choice. The number of wineries in the Martinborough Region grew from four in 1984 to thirty-nine in $2008 .{ }^{76}$ The original five-kilometre appellation area was at capacity. Later in the decade the decision was made to extend the appellation to topographically and climatically similar land in the middle valley of the Huangarua River, along Te Muna Road. ${ }^{77}$

In 2006, the New Zealand Parliament finally passed the Geographical Indications (Wine and Spirits) Registration Act. Legislation that acknowledged the provenance of produce had not existed prior, due to a perception that geographical indicators would threaten that attractiveness of New Zealand's mass-marketed land based commodities such as dairy products. ${ }^{78}$ The Martinborough Winemakers Association was quick to protect the 'Martinborough' label establishing a geographical index in the same year. ${ }^{79}$

\footnotetext{
72 Overton and Murray, 'Finding a place for New Zealand Wine; Terroir and regional denominations'. p.428.

73 See Fig. 4.

ibid. p.425.

74 ibid.

${ }^{75}$ Cormack, Martinborough Winemakers Oral History Project; Clive Paton, Tape 2, Side 1, Martinborough, 5th September 1990. Wairarapa District Archive, record no. OHA517.

${ }^{76}$ Cooper, The Wines and Vineyards of New Zealand. pp.126-139.

\& Cooper, Wine Atlas of New Zealand. pp.220-237.

77 See fig.4.

Murray and Overton, 'Defining Regions: the making of places in the New Zealand wine industry'. p.427.

${ }^{78}$ Overton and Murray, 'Finding a place for New Zealand Wine; Terroir and regional denominations'. p.45.

${ }^{79}$ Wellington Wine Country, 'Martinborough Geographical Indication', http://www.winesfrommartinborough.com/about martinborough/martinborough geographic indication 9gi0/index .htm. (accessed 02/03/2017).
} 
The legally recognised Martinborough Appellation expanded far beyond the geographic region specified by Derek Milne's original soil work. ${ }^{80}$ The need to facilitate the growth of the Martinborough wine industry resulted in the abandonment of the initial conception that the terroir of Martinborough was intrinsically bound to soil structure. Marketing strategies continued to refer to the alluvial soils of the region and increasingly emphasised the region's cool climate, its boutique nature and its physical and cultural similarities to the well regarded Burgundy Region.

${ }^{80}$ Murray and Overton, 'Defining Regions: the making of places in the New Zealand wine industry'. p.427. 
Fig. 4 Vineyard placement and appellation areas ${ }^{81}$

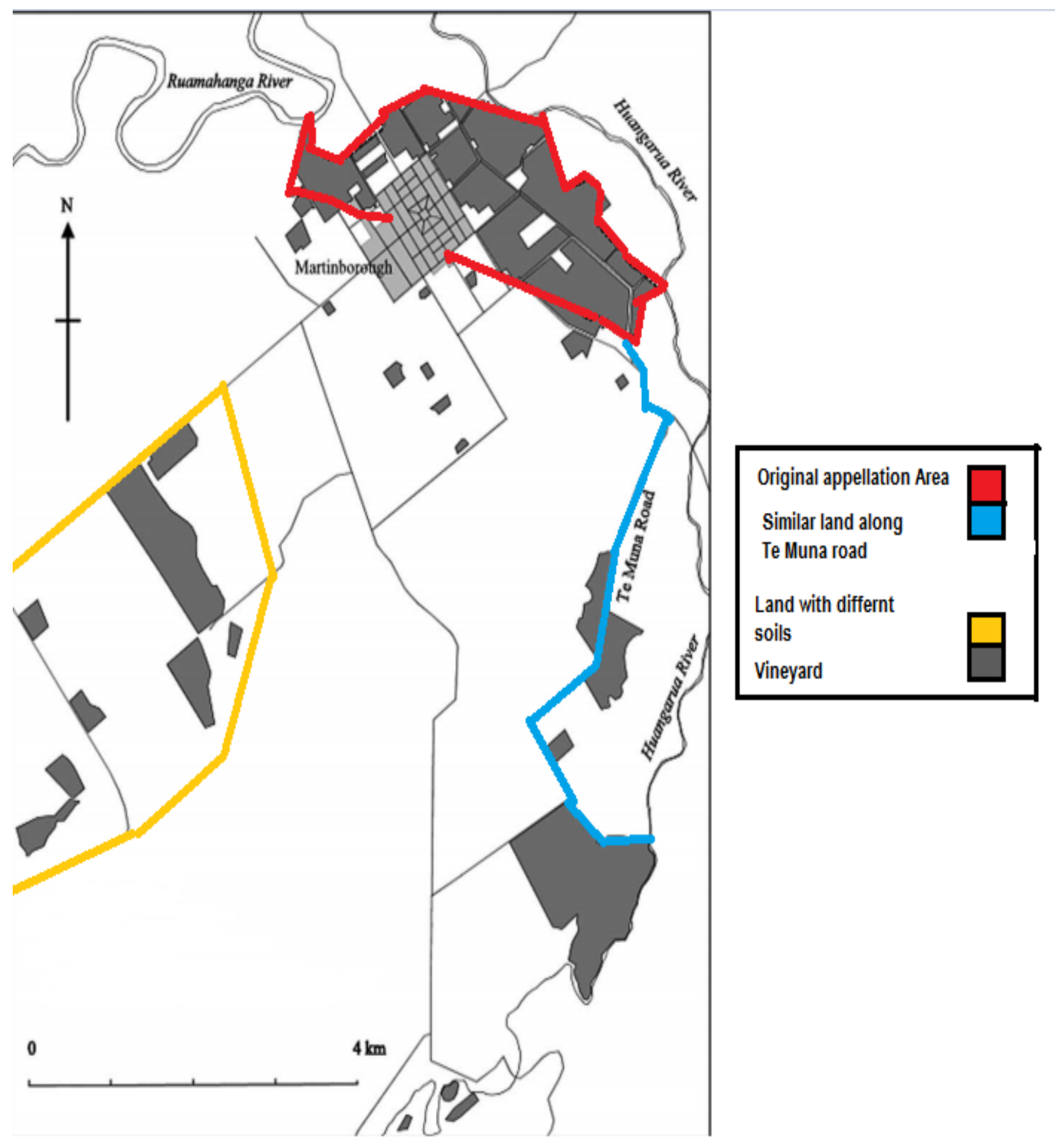

${ }^{81}$ See, Warwick Murray and John Overton, 'Defining Regions: the making of places in the New Zealand wine industry'. p.427. 


\section{The growth of grapevine capital}

A focus of on boutique, top end wines rather than table wines, enabled the pioneers to avoid the competition of normal retail distribution channels. ${ }^{82}$ However, as the region's profile grew, foreign interest and investment began to grow. A dynamic of competition and commodification replaced the industry's initial dynamic of camaraderie and co-existence. Throughout its development the Martinborough wine industry has established a number of marketing schemes to accentuate its exclusivity and difference, from the Martinborough Appellation to the emphasis placed on 'prize winning pinots and the development of the 'boutique wine village' tourism industry. Yet, the region continues to face competition from mass produced wines at export, largely due to New Zealand's international winemaking reputation.

Despite the identified need to diversify Martinborough industries, lifestyle changes, rather than financial gain appears to have been the primary motivation for the pioneering Martinborough winemakers. ${ }^{83}$ Of the initial four vineyards Chifney's was the only one owned outright by an individual. ${ }^{84}$ Ata Rangi, Dry River and Martinborough Vineyard were all, at least initially, divided amongst local shareholders who exercised varying levels of participation in the vineyard's development. ${ }^{85}$ In every instance at least one of the original partners remained in the vineyard and winery in a management capacity. Aside from purchasing land, vines, chemicals and equipment, the average four years that plants required to mature to a harvestable level was an added financial strain. ${ }^{86}$ Neil McCallum, Clive Paton and Stan Chifney all emphasise the lifestyle choice that they made in deciding to develop vineyards. ${ }^{87}$ Neil McCallum told Heather Cormack in 1990, 'a winery such as ours is not economic, you do it for quote, lifestyle reasons'. ${ }^{88}$

Financial circumstances also determined the early business decisions of the pioneer winemakers. A significant advantage of the business partnerships and close relationships between pioneer viticulturists was the exchange of ideas, equipment and services. Derek Milne was happy to offer

\footnotetext{
${ }^{82}$ Ann. B. Matasar, Women of Wine; The Rise of women in the Global Wine Industry, University of California Press, Berkeley, 2006. p.21.

${ }^{83}$ See, Cormack, Martinborough Winemakers Oral History Project.

${ }^{84}$ Cormack, Martinborough Winemakers Oral History Project; Stan Chifney, Tape 2, Side 2.

${ }^{85}$ See, Cormack, Martinborough Winemakers Oral History Project.

${ }^{86}$ Cormack, Martinborough Winemakers Oral History Project; Larry McKenna, Tape 2, Side 1, Martinborough, 13/08/1990. Wairarapa District Archive, record no. OHA495.

${ }^{87}$ Cormack, Martinborough Winemakers Oral History Project; Neil McCallum, Tape 1, Side 2. Cormack, Martinborough Winemakers Oral History Project; Stan Chifney, Tape 2, Side 2.

\& Cormack, Martinborough Winemakers Oral History Project; Clive Paton, Tape 1, Side 2, Martinborough, 5/09/1990. Wairarapa District Archive, record no. OHA517.

${ }^{88}$ Cormack, Martinborough Winemakers Oral History Project; Neil McCallum, Tape 2, Side 2.
} 
soil advice to other viticulturists. ${ }^{89}$ Clive Paton lent his tractor to the proprietors of the other wineries. ${ }^{90}$ Stan Chifney, who lived on his vineyard in Martinborough, would check up on the vineyards of those proprietors whose second jobs took them away from the region. ${ }^{91} \mathrm{~A}$ lack of finances prevented most of the pioneering viticulturists from developing wineries, they 'chipped in,' for equipment and used the Chifneys' winery until they had enough revenue to open their own. ${ }^{92}$ The respondents of Heather Cormack's interviews recalled a sense of community and camaraderie in the early years of the industry. Although they did not imply that this community had disbanded by 1990 , they were beginning to reflect upon the competitive nature of the industry, particularly around market time..$^{93}$

The competitive nature of the industry and the commodification of the Martinborough grape surged through the 1990s. The boutique nature of the Martinborough wine industry had protected early producers from the wine glut of the $1980 \mathrm{~s} .{ }^{94}$ Yet, the relative success of the regions wines and the successful marketing of the region drew a significant amount of interest. ${ }^{95}$ Phyllis Paton of Ata Rangi Vineyard identified in 1990 that more competition in the market place meant that she and partner Clive were going to have to work much harder to keep their high profile. ${ }^{96}$ Notions of quality that had become synonymous with Martinborough had polar effects; the exclusivity of Martinborough wines had ensured that they fetched high prices from a loyal customer base, ${ }^{97}$ conversely, the necessity to expand the appellation out in order to make room for new winemakers resulted in greater competition within the high-end wine market. ${ }^{98}$

\footnotetext{
${ }^{89}$ Cormack, Martinborough Winemakers Oral History Project; Neil McCallum, Tape 1, Side 2.

${ }^{90}$ Cormack, Martinborough Winemakers Oral History Project; Clive Paton, Tape 1, Side 2.

${ }^{91}$ Cormack, Martinborough Winemakers Oral History Project; Stan Chifney, Tape 2, Side 2.

${ }^{92}$ Cormack, Martinborough Winemakers Oral History Project; Clive Paton, Tape 1, Side 2.

${ }^{93}$ Cormack, Martinborough Winemakers Oral History Project; Tom Draper, Tape 2, Side 1, Martinborough, 27/08/1990. Wairarapa District Archive, record no. OHA513.

${ }_{94}$ Matasar, Women of Wine. p.21.

${ }^{95}$ Otto Pohl, 'New Zealand Stokes Its Wine Ambitions', The New York Times, 03/03/2004. http://www.nytimes.com/2004/03/03/business/new-zealand-stokes-its-wine-ambitions.html? r=0. (accessed 28/06/2016).

${ }^{96}$ Cormack, Martinborough Winemakers Oral History Project; Phyllis Paton, Tape 2, Side 1.

97 'Pinot Pioneer', Dominion Post; Supplement, Wellington, New Zealand, 03/12/2011. p.14.

${ }^{98}$ Cormack, Martinborough Winemakers Oral History Project; Neil McCallum, Tape 2, Side 2.
} 
Fig.5 ${ }^{99}$ Wine companies by size as at June 2016

\begin{tabular}{|l|l|l|}
\hline Category & $\begin{array}{l}\text { Number of Wineries } \\
\text { in NZ }\end{array}$ & $\begin{array}{l}\% \text { of total number } \\
\text { of wineries }\end{array}$ \\
\hline $\begin{array}{l}\text { Large (wine sales exceeding } \\
4 \text { million litres) }\end{array}$ & 17 & $3 \%$ \\
\hline $\begin{array}{l}\text { Medium (wine sales between } \\
200,000 \text { and } 4 \text { million litres) }\end{array}$ & 69 & $10 \%$ \\
\hline $\begin{array}{l}\text { Small (wine sales not } \\
\text { exceeding 200,000 litres) }\end{array}$ & 587 & $87 \%$ \\
\hline
\end{tabular}

The early 1980s was a troublesome period for the New Zealand wine industry. A group of scientific studies found that the illegal process of wine-watering, in which water was used to stretch the amount of wine produced, was common. ${ }^{100}$ Furthermore, the wine glut of the 1980s, much like the crisis in farming, originated from productivist policy supported by Government incentives for development. By 1985 the New Zealand crushed 25\% more grapes than was necessary to meet national demand, resulting in a record surplus of wine. ${ }^{101}$ The exclusive and boutique nature of the Martinborough wine industry, in which quality was stressed over quantity, protected it from the wine glut of the 1980s; the wineries were exempt from allegations of wine-watering due to their low production levels and reputation for quality and production levels aimed to meet demand, not exceed it.

On the international scale the region's reputation came in to competition with the winemaking reputation of New Zealand itself. ${ }^{102}$ Martinborough wines did not enjoy the same distinction internationally as they did nationally. Larger and longer established brands such as Marlborough's Cloudy Bay were both significantly cheaper and better known to import markets. ${ }^{103}$ While the

\footnotetext{
${ }^{99}$ ANZ \& New Zealand Winegrowers, New Zealand Wine Industry: Full Bodied Growth, June 2016. p.2. file:///C:/Users/User/Downloads/NZ-Wine-Industry-Full-Bodied-Growth.pdf. (accessed 01/05/2017).

100 Cooper, Wine Atlas of New Zealand. p.17.

101 ibid.

102 Overton and Murray, 'Finding a place for New Zealand Wine; Terroir and regional denominations'. p.46.

${ }^{103}$ Neil McCallum, 'Wine', The Butcher's Talk Series, Victoria University of Wellington, Lecture Theatre 4, Faculty of Law, Government Buildings, Wellington, 08/05/2016.
} 
exclusivity and boutique nature of the Martinborough wine industry aided its performances on national markets, internationally it was arguably as detrimental as it was effective.

\section{Fig. $6^{104}$ Share of wine exports by company size}

\begin{tabular}{|l|l|l|l|l|}
\hline Year & $\begin{array}{l}\text { Large Wineries (wine } \\
\text { sales more than 4 million } \\
\text { litres) }\end{array}$ & $\begin{array}{l}\text { Medium Wineries (wine } \\
\text { sales between 200,000 and } \\
4 \text { million litres) }\end{array}$ & $\begin{array}{l}\text { Small Wineries } \\
\text { (wine sales not } \\
\text { exceeding 200,000 } \\
\text { litres) }\end{array}$ \\
\hline 2011 & $48.6 \%$ export share & $38 \%$ export share & $13.4 \%$ export share \\
\hline 2016 & $64.1 \%$ export share & $22.3 \%$ export share & $13.6 \%$ export share \\
\hline
\end{tabular}

Marketing of Martinborough was important for the development of the wine industry. Drawing upon the Burgundy comparison, the region began to build a reputation for itself based upon preconceived notions of grandeur attributed to the French region. By drawing parallels with a preexisting, internationally revered wine region Martinborough drew increased international attention. International winemakers and investors began to be drawn to the region, which offered 'old world' terroirs for a fraction of the price. Despite the price of land more than doubling between 2000 and 2004 , at an average of $\$ 40,000$ an acre a prime New Zealand vineyard was still nearly half the price of $\$ 70,000$ an acre land prices in the Napa Valley. ${ }^{105}$ Comparatively inexpensive vineyard acreage and high returns made the region an attractive, and cheaper alternative to other international mainstays of the wine industry. ${ }^{106}$

Foreign investment developed in two distinct ways, foreign absentee ownership and migrant ownership. The first was to have the most pronounced effect on the economic and environmental fabric of the region. By 2005 four of the twenty-three Martinborough vineyards were internationally owned and locally operated, Craggy Range, Dry River Wines, Julicher and Te Kairanga. ${ }^{107}$

\footnotetext{
${ }^{104}$ ANZ \& New Zealand Winegrowers, New Zealand Wine Industry.

105 Pohl, 'New Zealand Stokes Its Wine Ambitions'.

106 Matasar, Women of Wine. p.103.

107 See New Zealand Wine, Wairarapa Wine NZ; Explore all Wineries, http://www.nzwine.com/regions/wairarapa/\#explore-wineries. (accessed 24/05/2016).
} 
International entrepreneurs such as American billionaire businessman Bill Foley, American billionaire hedge fund manager Julian Robertson and American wine-grower and businessman Reginald Oliver bought pre-existing vineyards with capital gains in sight. ${ }^{108}$ The corporate dimension of the industry was to play a far more significant role. Bill Foley expressed his intention to vertically integrate the Te-Kairanga winery with the production and distribution branches of his Winec Company. ${ }^{109}$ These new avenues of disbursement presented another dimension of competition to the previously cellar door and mail order oriented nature of the Martinborough wine trade. This dynamic of ownership added to the competitiveness of the industry and challenged the initial atmosphere of community and camaraderie.

The second, migrant ownership did little to disturb the economic and social balance of Martinborough. Reports suggest that foreign absentee owners were the recipients of local disdain toward foreign ownership. ${ }^{110}$ The Martinborough wine industry was of a metropolitan makeup from its conception. Stan Chifney, Larry McKenna, and Wyatt Creech were all born overseas, and most of the other pioneer winemakers spent extended periods travelling internationally before establishing businesses in Martinborough. ${ }^{111}$ Although financial returns were likely to have been more of a drawing point in later years the competition of other vineyards, corporate investment, heightened cost of land and the investments required for technology, goods, equipment and manufacture, presented an economic climate far harsher than that experienced by the 'core' group of initial viticulturists in the 1980 s. ${ }^{112}$

The socio-economic change most frequently ascribed to Martinborough is the rise of the winetourism industry in the region. Peter Howland has written about the habitus of the region's wine tourists and numerous journalists and scholars acknowledge the importance of tourism to the region's economy. However, few pieces of scholarship address the social and economic drivers that led to, and determined the shape of the Martinborough tourism industry.

The Martinborough Appellation and its Burgundian comparison was arguably the most important factor in the development of the region's tourist trade. Stan Chifney reflected in 1990 that the

\footnotetext{
108 Pohl, 'New Zealand Stokes Its Wine Ambitions'.

\& Mary Ann Worobiec, 'Foley Family Wines Expands in New Zealand', Wine Spectator, February 7th 2014. http://winespectator.com/webfeatures/show/id/49596. (accessed 28/06/2016).

109 Worobiec, 'Foley Family Wines Expands in New Zealand'.

110 Pohl, 'New Zealand Stokes Its Wine Ambitions'.

${ }^{111}$ See, Cormack, Martinborough Winemakers Oral History Project.

112 Matasar, Women of Wine. p.161.
} 
appellation was essentially a 'promotional, marketing thing. ${ }^{\prime 13}$ The notion of an appellation, which links a consumer product to a geographic region, is bound to draw attention to that area. The exclusivity of wine sales necessitated the development of the accommodation industry; cellar door and mail order trading ensured that in order to buy the wine, people had to visit the vineyard. Howland notes that the demographic of the town changed significantly between 1970 and 2005, with guest accommodation offerings multiplying more than fifty times over. ${ }^{114}$ The appellation itself had also determined the shape of the town's physical development, by the 1990s the town had a strong physical resemblance to Phyllis Paton's image of Burgundian villages, penned in by vineyards. ${ }^{115}$ This physical appearance of a 'wine village' alongside the smaller industries that developed in the town became a further drawing point for holidaymakers seeking an idyllic break from city life. ${ }^{116}$

\section{Fig.7. ${ }^{117}$}

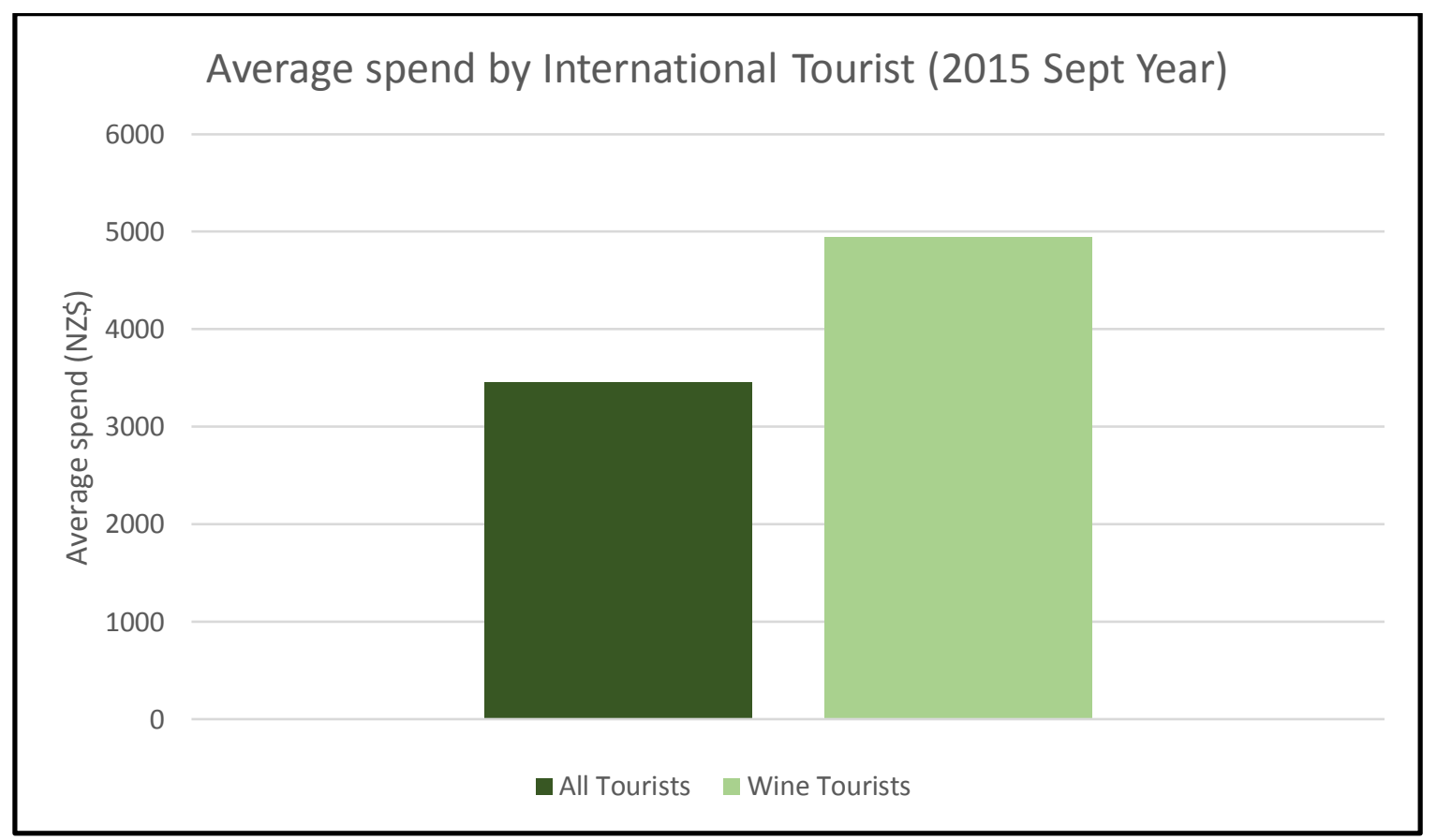

\footnotetext{
${ }^{113}$ Cormack, Martinborough Winemakers Oral History Project; Stan Chifney, Tape 3, Side 2.

${ }^{114}$ Howland, 'Martinborough's Wine Tourists and the Metro-Rural Idyll'. p. 79.

115 Cormack, Martinborough Winemakers Oral History Project; Phyllis Paton, Tape 2, Side 1.

${ }^{116}$ Howland, 'Martinborough's Wine Tourists and the Metro-Rural Idyll'. p. 77.

${ }^{117}$ ANZ \& New Zealand Winegrowers, New Zealand Wine Industry. p.5.
} 
Joanna Fountain has identified that in the competitive wine market, it is important to engage young consumers. ${ }^{118}$ The exclusivity and subsequent expense of Martinborough wines may render them outside of the budget of younger consumers. Yet, winemakers have clearly acknowledged the insights of Fountain, and have addressed the necessity in ways that closely intertwine Martinborough's tourist industry and wine industry. Toast Martinborough began in 1993, a wine, food and music festival located in the town and its vineyards. ${ }^{119}$ The festival is very successful, which is perhaps unsurprising given the popularity of the Martinborough Region, particularly amongst Wellingtonians; ${ }^{120}$ in 2010 the 10,000-ticket capacity was reached within five and a half hours of going on sale. ${ }^{121}$ Festival attendance is cross-generational, highlighting the cleverness of including the wine industry in a festival package. Furthermore, the festival is relatively affordable. In 2015 the adult ticket price was $\$ 70$, significantly less than the price of a bottle of Dry River pinot noir. ${ }^{122}$ The festival serves the purpose of achieving an on the day income, but also of generating interest in the industry.

It is interesting to note that the Toast Martinborough entrenches the cultural capital of the wine village. While there is no dress code, the pressure to dress well is evident in photos of the event over the years. Whether this is due to the implication of celebration in the name 'Toast,' or to a perceived notion of prestige attached to the festival and region is unknown. Yet, reports and complaints from residents, and festivalgoers about pre-loading and overly intoxicated youths suggests that the habitus of attendees is not congruent. In 2011 a police officer overseeing the event stated of a number of young female attendees, 'If their mothers could see them, they'd shut the festival down tomorrow'. His sentiments were echoed by a number of Martinborough residents who stated that the 'once civilised wine-lovers event is now a mass booze-up'. ${ }^{123}$ These observations

\footnotetext{
118 Joanna Fountain \& Charles Lamb, 'Generation Y as young wine consumers in New Zealand; How do they differ from Generation X?', International Journal of Wine Business Research, Patrington, 23:4, 2011. p.107.

119 Toast Martinborough Wellington, 'All about Toast', http://toastmartinborough.co.nz/your-first-festival/. (accessed 20/04/2017).

${ }^{120}$ Cormack, Martinborough Winemakers Oral History Project; Clive Paton, Tape 1, Side 2.

121 Seamus Boyer, 'Toast Martinborough tickets sell out within a day', Stuff: Wairarapa, 03/10/2012.

http://i.stuff.co.nz/dominion-post/news/wairarapa/7764067/Toast-Martinborough-tickets-sell-out-within-day. (accessed 20/04/2017).

122 Caleb Harris, 'Nerves and delight as Toast Martinborough tickets go on Sale', Stuff NZ, 22/08/2015. http://i.stuff.co.nz/dominion-post/news/72302529/nerves-and-delight-as-toast-martinborough-tickets-go-on-sale. (accessed 20/04/2017).

\& Wine Searcher, '2014 Dry River, Pinot Noir, Martinborough New Zealand'. http://www.winesearcher.com/find/dry+river+pinot+noir+martinborough+new+zealand/2015. (accessed 20/04/2017).

${ }^{123}$ Society for Promotion of Community Standards, 'Abuse of Alcohol at Toast Martinborough Wine Festival', 22/12/2011. http://www.spcs.org.nz/abuse-of-alcohol-at-toast-martinborough-wine-festival/. (accessed 20/04/2017).
} 
highlight the cultural difficulty of achieving multi-generational appeal and the un-ease with which the town's resident population can sometimes meet marketing techniques.

\section{From ghost town to grape town}

The Martinborough wine industry breathed new life into the struggling farming town. Until the mid1980's Martinborough had been the quiet rural centre for the pastoralists of the Martinborough Plains, yet by the 1970 s long-term residents had begun to describe it as a 'ghost town'. ${ }^{124}$ All scholars agree that the wine industry has changed the social fabric of Martinborough. However, few address these social alterations, both within the wine trade, and the greater Martinborough community. Neil McCallum observed in 1990 that Martinborough was a very 'class ridden town'. ${ }^{125}$ Where Martinborough viticulturists fit, in the traditional pastoral class fabric of the town is an understudied and significant aspect of the development of the region. Observing the social changes that occurred both within the Martinborough wine industry and the town itself enables a painting of the industry's true socio-economic influence.

The pioneering Martinborough viticulturists responded in unanimous agreement to Heather Cormack's question of how the town's residents regarded them, Martinborough residents thought they were mad. ${ }^{126}$ Although they were all of middle class upbringing, Stan Chifney acknowledged the traditional perception of viticulture as being a sport for the rich. ${ }^{127}$ It is a fair assumption that locals may meet newcomers undertaking a class written profession in a struggling economic climate with antagonism; there is little evidence of this. Roberta Mclntyre concludes that most landowners and farmers did not associate with the winemakers. ${ }^{128}$ Sources suggest that class antagonism did not occur and that viticulturists and farmers stuck to their own status groups in the early years.

When conflict occasionally occurred, it did so with regard to particular environmental and economic issues. Roberta Mclntyre refers to an infrastructural skirmish over the sealing of roads. The MWA suggested the sealing of two roads to the east of the town, where there were a number of vineyards: Huangarua road and Purutanga road. Featherston's traditional pastoralist councillors favoured the sealing of back country roads to the south, in order to facilitate the farming and fishing industries of

\footnotetext{
${ }^{124}$ Howland, 'Euro-chic, Benign Cosmopolitanism and Wine Tourism in Martinborough, New Zealand'. p.113

\& Chris Fogarty, 'Tiny town with a grape potential', Sunday Star Times, April 17th 1994, 76cm, p.c9, Issn: 1172-9740, National Library of New Zealand Microfilm: Sunday Star Times, Mar-April 1994.

${ }^{125}$ Cormack, Martinborough Winemakers Oral History Project; Neil McCallum, Tape 2, Side 2.

${ }^{126}$ See, Cormack, Martinborough Winemakers Oral History Project.

${ }^{127}$ Cormack, Martinborough Winemakers Oral History Project; Stan Chifney, Tape 3, Side 2.

${ }^{128}$ Mclntyre, Canoes of Kupe: a History of the Martinborough District. p. 271.
} 
Cape Palliser and Pirinoa. ${ }^{129}$ The use of pesticide and herbicide sprays was also an early point of contention. Farmers complained that these chemicals were toxic, and damaged their crops. ${ }^{130}$ Sprays such as paracot pre-grown and surflan could inhibit seed growth if they found their way onto farms. ${ }^{131}$ By far the most common point of dispute was birdlife; the shotguns and bangers used by viticulturists to deter birds were noisy and disturbed the local residents. ${ }^{132}$ Furthermore, farmers actually encouraged starlings because they were a form of grass-grub control. ${ }^{133}$ So the issue of how to deal with the fauna of the region became an ongoing back and forth between farmers and viticulturists. There is nothing to suggest that these technical disagreements were malicious or antagonistic; rather, they were a consequence of two industries, with different needs, co-existing within a region that had previously been home to just one.

Cormack's interviews reveal that by 1990 the pioneering Martinborough winemakers felt that Martinborough society had accepted them. Neil McCallum reported, 'Now there is a proportion of the town that is very much behind us and accepts us $^{\prime} .{ }^{134}$ Numerous sources suggest that viticulture saved Martinborough from decline. Third generation Martinborough resident Conor Kershaw remembered in 2011, 'Growing up as a kid I really wanted to leave Martinborough, but then the wine industry arrived with all its intricacies and it became a funky little town'. ${ }^{135}$

Many of the winemakers spoke of the employment opportunities that the industry had bought to the region, yet lamented that the seasonal nature of the work and lack of finances meant that they could not employ as many people as they would like. ${ }^{136}$ The rise of the wine tourism industry also provided job opportunities, but between 2001 and 2013 the employment rate peaked, and then dropped again. ${ }^{137} \mathrm{~A}$ significant statistic considering that the permanent resident population of Martinborough also decreased; ${ }^{138}$ while this may be taken as a suggestion that the wine industry provided fewer employment opportunities than reported, it is also explicable by two factors of the

\footnotetext{
129 ibid.

130 ibid.

${ }^{131}$ Cormack, Martinborough Winemakers Oral History Project; Stan Chifney, Tape 2, Side 2.

132 Cormack, Martinborough Winemakers Oral History Project; Clive Paton, Tape 1, Side 2.

${ }_{133}$ Cormack, Martinborough Winemakers Oral History Project; Larry McKenna, Tape 2, Side 1.

134 Cormack, Martinborough Winemakers Oral History Project; Neil McCallum, Tape 2, Side 2.

${ }^{135}$ Katie Farman, 'Martinborough, Outside the Square', Fishhead Magazine, October-November 2011, Microfilm, Wellington City Libraries, N0518678628. p.43.

${ }^{136}$ See, Cormack, Martinborough Winemakers Oral History Project, 1990-91.

137 '2013 Quick Stats about a place; South Wairarapa District', Statistics New Zealand, http://www.stats.govt.nz/Census/2013-census/profile-and-summary-reports/quickstats-about-aplace.aspx? request value=14536\&tabname=\#.

${ }^{138}$ Howland, Metro-rurality, social distinction \& ideal reflexive individuality. p.28.
} 
demographic development of Martinborough. Firstly, it reflects the increase in the number of retirees and semi-retirees resident in Martinborough. ${ }^{139}$ Secondly, it reflects a rise in the number of holiday homes and non-permanent dwellings in the area. ${ }^{140}$ This changing demographic caused disagreement as the industry developed; the increasing numbers of holiday homes meant that permanent residents no longer knew their neighbours, ${ }^{141}$ some resented the influx of wine tourists and foreign ownership, particularly as costs and land prices increased. ${ }^{142}$ As winemakers became an accepted facet of Martinborough society the notion of the 'other' became associated with tourists and foreign investors.

The Martinborough industry reinforced and challenged the traditional masculinity of winemaking. Ann Matasar notes that throughout history the wine industry has excluded women from positions of power and influence. ${ }^{143}$ The inception of the Martinborough wine industry was male dominated; ${ }^{144}$ a number of the founding shareholders had met at Danny Schuster's wine tasting club, a gathering reminiscent of the 'male only' wine tasting clubs of both the Old and New World vintner's scenes. ${ }^{145}$ Rosemary Chifney was in many ways the archetype of a winemaker's wife, involved with the business only in an administrative and hospitality capacity. ${ }^{146}$ The commitment of winemakers to hiring predominantly female pickers and pruners, while seemingly progressive, was typical of old world viticultural sentiment, where picking and sorting were seen as tasks that required feminine attributes such as patience and caring. ${ }^{147}$

The first prominent female winemaker to appear on the Martinborough wine scene was Clive Paton's wife Phyllis, who became a shareholder and winemaker at Ata Rangi in $1987 .{ }^{148}$ Having previously worked at Montana in Blenheim, Phyllis was one of the most experienced of the early Martinborough winemakers. ${ }^{149}$ She shared the winemaking with husband Clive, yet continued to

\footnotetext{
139 Katie Farman, 'Martinborough, home for good?', Fishead Magazine, February 2013, Issue 12. p.46.

140 Howland, Metro-rurality, social distinction \& ideal reflexive individuality. p. 28.

${ }^{141}$ Helen Bain, 'Boomtown on the plains.' Dominion Post weekend magazine, 9 February 2002, p.3.

142 See, Howland, 'Martinborough's Wine Tourists and the Metro-Rural Idyll'.

Bain, 'Boomtown on the plains.'p.3

\& Pohl, 'New Zealand Stokes Its Wine Ambitions'.

${ }^{143}$ Matasar, Women of Wine. p.1.

${ }^{144}$ See, Cormack, Martinborough Winemakers Oral History Project.

145 See, Cormack, Martinborough Winemakers Oral History Project.

\& Matasar, Women of Wine. p.7.

${ }^{146}$ Cormack, Martinborough Winemakers Oral History Project; Rosemary Chifney, Tape 2, Side 2, Martinborough, 22/08/1990, Wairarapa District Archive, record no. OHA503.

147 Matasar, Women of Wine. p.10.

148 Cormack, Martinborough Winemakers Oral History Project; Phyllis Paton, Tape 1, Side 2.

149 ibid.
} 
find herself locked into the stereotypical female roles of hospitality and administration. ${ }^{150}$ Women began to be more prominent as the industry developed, however New Zealand wide if there was a job going for a viticulturist, winemaker or estate manager, men were likely to be offered the role over women. ${ }^{151}$

\section{The wrath of grapes?}

The Viticulture industry has its own environmental footprint. Environmental and ecological change is attributable to the human activities of planting and nurturing vines and producing wines. This has interesting implications for the subjectivities of winemakers, for whom running a 'sustainable' operation is higher risk and more labour intensive, but often sought after by consumers of high-end wines.

The proximity of the Martinborough Terraces Appellation, and later the Martinborough Appellation, to the Huangarua River, brought with it a number of environmental considerations. While the alluvial soils of the riverbed were ideal for viticultural development, the techniques of Martinborough viticulturists had a detrimental impact on the water quality of the river. Although irrigation demands for viticulture are significantly lower than for agricultural production, the viticulture industry still contributes to the dredging of river channels for water, which has led to low water tables and compromised micro-invertebrate growth. ${ }^{152}$ The application of chemicals and fertilisers to vines also contributed to the pollution of waterways through chemical and fertiliser run-off. ${ }^{153}$

A heightened attention to viticulture's environmental footprint, and New Zealand's winemaking reputation emerged in the 1990s. Sustainable Winegrowing New Zealand (SWNZ) was established in 1995 to enforce ecological protection of the New Zealand environment and wine industry through nine pillars of sustainability; biodiversity, soil, water, air, energy, chemical, by-products, people and business. ${ }^{154}$ Many of its pillars became entrenched by the introduction of winery standards in $2002 .{ }^{155}$

\footnotetext{
150 ibid.

151 Tracey Barker, “Women-only wine group launches in New Zealand”, Decanter, 09/10/2002.

http://www.decanter.com/wine-news/women-only-wine-group-launches-in-new-zealand-105729. (accessed 28/06/2016).

152 Royal, Cultural Values for Wairarapa Waterways.p.73.

153 ibid.

154 SWNZ, Sustainable Winegrowing New Zealand Standards, nzwine.com/sustainability. (accessed 10/05/2016).

155 New Zealand Wine, 'Sustainable Winegrowing New Zealand', http://www.nzwine.com/assets/Sustainability/Sustainable\%20Winegrowing\%20New\%20Zealand.pdf. (accessed 14/07/2016).
} 
Initiatives designed toward biological, rather than chemical vineyard management, were met with mixed reviews. Stan Chifney said of the outlawing of the bird deterrent mesurol, 'I'm very much anti-do-gooders.' ${ }^{156}$ Neil McCallum, on the other hand, expressed desires to establish his vineyard as organic in 1990, well before the establishment of the SWNZ. ${ }^{157}$ All Martinborough winemakers and wineries are now SWNZ accredited and many achieve higher, optional standards such as organic and biodynamic. ${ }^{158}$ From 2010 onwards, in order to be eligible for New Zealand winemaker events, awards and promotions, winemakers had to be audit accredited. ${ }^{159}$ Furthermore, a number of studies have found that winegrowers adopt environmental practices for reasons pertaining to exclusivity, ideology and economics alongside environmental concerns. ${ }^{160}$ It is incredibly difficult to separate the intention of environmental sustainability from consumer and shareholder demand for the 'green image' of ecologically sustainable and profitable enterprises-such as organic wines. ${ }^{161}$

\footnotetext{
${ }^{156}$ Cormack, Martinborough Winemakers Oral History Project; Stan Chifney, Tape 2, Side 2.

157 Cormack, Martinborough Winemakers Oral History Project; Neil McCallum, Tape 1, Side 2.

${ }^{158}$ According to their respective websites accessed through: http://www.nzwine.com/regions/wairarapa/\#explorewineries.

159 SWNZ, Audit Procedures for Vineyards and Wineries, http://www.nzwine.com/assets/sm/upload/i1/dh/fa/9b/SWNZ\%20AUDIT\%20PROCEDURES\%20.pdf. (accessed 10/05/2016).

${ }^{160}$ See, Gabzdylova, Raffensperger and Castka, 'Sustainability in the New Zealand Wine Industry: drivers, stakeholders and practices'.

Mark Cordano, R. Scott Marshall \& Murray Silverman, 'How Do Small and Medium Enterprises "Green”? A Study of Environmental Management Programs in the U.S Wine Industry', Journal of Business Ethics, Vol. 92, No. 3, March 2010. pp.463-478.

\& David Thompson \& Sharon. L. Forbes, "Going "green" to find "gold" in wine: A case study of a New Zealand wine producer', 6th AWBR International Conference, Bordeaux Management School, 9-10 June 2011.

http://researcharchive.lincoln.ac.nz/bitstream/handle/10182/4022/going green to find gold.pdf?sequence=3. (accessed 15/07/2016).

${ }^{161}$ Howland, 'Euro-chic, Benign Cosmopolitanism and Wine Tourism in Martinborough, New Zealand'. p.124.
} 


\section{A grape ending}

The Martinborough wine industry is often credited with having breathed new life into a dying region. Viticultural development has extended throughout the Wairarapa with the emergence of other successful winegrowing regions further north, such as Gladstone and Opaki. ${ }^{162}$ There has been an interdisciplinary interest in the economic and tourism aspects of the industry's development, but few scholars have addressed the inter-relation between these factors, and the environmental and social development of the region. The industry brought with it new environmental challenges and implications, social dynamics and business strategies. Both the geographical layout of the town and the ideological conception of it, have been shaped by the wine industry.

The pioneer Martinborough winemakers appear to have entered the industry for interest and lifestyle reasons rather than capital gain; however, financial necessity, consumerism and competition introduced a corporate dimension to the burgeoning industry. The terroir of the region became less bound to the soil science upon which the Martinborough Terraces Appellation was founded and more upon the branding of the region as a cool climate Burgundian wine village. Exclusivity was a fundamental requisite for the achievement of the high price tags attached to the products of the boutique vineyards. Thus, the town developed along the lines of what Howland has referred to as a 'Euro-chic' habitus, heavily emphasising the rhetoric of the BurgundyMartinborough comparison. ${ }^{163}$

This notion of exclusivity and the ideology of quality over quantity was further emphasised by observation of sustainable winemaking practices and the perpetuation of green ideology associated with the perceived middle class values of a 'clean, green New Zealand.'164

International interest and foreign investment in the industry added an extra dimension of corporate competitiveness that challenged and changed the initial dynamic of camaraderie that existed within the early Wairarapa winemaking community. The increased presence of 'foreigners' creating a twofold dynamic within the town; tourism was praised for the economic development of the region, but resented by some permanent residents due to the disruptive effect that it had on their community.

\footnotetext{
162 Cooper, Wine Atlas of New Zealand. p.214.

163 See, Howland, 'Euro-chic, Benign Cosmopolitanism and Wine Tourism in Martinborough, New Zealand'. p. 113-129.

${ }^{164}$ Howland, 'Euro-chic, Benign Cosmopolitanism and Wine Tourism in Martinborough, New Zealand'. p.124.
} 
Class conflict did not feature visibly in the establishment of the Martinborough wine industry despite the economic decline of the 'old money' of farming communities and the somewhat antagonistic notion of a new industry that would reform the fabric of the region. While relations between Martinborough residents and incumbent winemakers were best described as distant, conflict primarily occurred with regard to technical issues and infrastructural disagreements. Status antagonism became apparent, only as tourism and foreign investment became significant features of the town. The development of an 'us versus them' mentality is exemplified by the resentment of some residents toward tourists, and by the perceptions held by some tourists that the town's residents were 'country bumpkins'. ${ }^{165}$

The development of the Martinborough wine industry is an exemplar of how cultural imperatives, social and economic needs, shape both the physical and metaphorical environments in which they operate. Both visibly and ideologically, Martinborough experienced a transformation from a small pastoral servicing town to an internationally renowned boutique wine village.

${ }^{165}$ Howland, 'Martinborough's Wine Tourists and the Metro-Rural Idyll'. p.80. 


\section{Chapter 3: Ngāti Kahungunu ki Wairarapa and Rangitāne o Wairarapa}

\section{'You can't get kai from the river any more'1}

For Pākehā in the South Wairarapa perceptions and issues are temporally bound in the happenings of the past century. For Rangitāne o Wairarapa and Ngāti Kahungunu Māori they have a longer historical trajectory, bound in cultural and spiritual links to the region, passed down through whakapapa and legend over the past 850 years. $^{2}$ Where Pākehā have traditionally placed value in the suitability of land for development and agricultural production, South Wairarapa Māori have emphasised the value of the region's waterbodies. The Southern coastline, Wairarapa Moana and Ruamāhanga River are significant to Tangata Whenua both in terms of historical settlement and Māori mythology. While the past two chapters have primarily focussed on changes in land use, the following has an increased emphasis on the water resources of the region. Alongside discussion of the social and economic repercussions of neoliberal reform for South Wairarapa Māori this chapter will address the ways in which the ability for Māori to act as kaitiaki over the regions waterbodies has been influenced by the changes of the past thirty years.

The geographical boundaries of the South Wairarapa created by the LGA are particularly arbitrary for South Wairarapa Māori. Rangitāne o Wairarapa and Ngāti Kahungunu Māori have connections not only with the two marae located within the boundary, Papawai Marae in Greytown and Kohunui Marae just outside Pirinoa, but also with Hurunui-O-Rangi Marae in Gladstone and Te Ore-Ore Marae in Masterton. ${ }^{3}$

The rohe of Ngāti Kahungunu also encompasses the Hawkes Bay region, which is outside the jurisdiction of both the SWDC and the GWRC. The whakapapa of South Wairarapa Māori frequently links them to geographic areas that lie outside of the lines of the LGA. Many sites of tapu for Rangitāne and Ngāti Kahungunu in the region, such as urupā, also lie outside of the government mandated confines of the SWDC.

These discrepancies are an important starting point for discussion because they identify continuing sites of difficulty in Iwi and government relations, land and resource management. As will be discussed in depth later in the chapter, many significant initiatives to include Māori in decision making and management of the South Wairarapa have been made over the past thirty years.

\footnotetext{
${ }^{1}$ The Wairarapa ki Tararua Report; Volume III. p.849.

${ }^{2}$ Bagnall, Wairarapa; an historical excursion. p.1.

${ }^{3}$ Rainford, Interview with Paora Ammunson.
} 
However, in some instances the ability of Iwi to act as kaitiaki is hindered by financial and social constraints.

The focus of this thesis upon the geographical boundary of the South Wairarapa, instated by the 1989 reforms, significantly limits the scope of this chapter. Where deemed necessary, discussion may concern sites that lie outside of this boundary. A contemporary historiographical study of the relationship between Rangitāne o Wairarapa and Ngāti Kahungunu ki Wairarapa Māori, and the entire geographical area of their rohe, is an area that requires further scholarship.

There is also an anachronism in confining the discussion of Ngāti Kahungunu and Rangitāne relations to the land within an affixed contemporary timeframe. As has been consistently re-iterated in this, thesis the environmental and societal changes of the past four decades cannot be observed in isolation from the longer trajectory of New Zealand history. This is conspicuously the case with regard to māoritanga and tikanga Māori. Rangitāne and Kahungunu Māori have a strong spiritual and cultural bond with their whenua which is linked to history through whakapapa. ${ }^{4}$ Furthermore, much of contemporary history, from the work of the Waitangi Tribunal to ongoing contestations over land use, and disparity in social, cultural and political capital, cannot be understood in isolation from the alienation of Māori land and earlier colonial policy. As has been done in the previous chapters, this chapter will examine the impact of neoliberal reforms upon Ngāti Kahungunu and Rangitāne Māori and their whenua within the context of the wider historical trajectory of Aotearoa.

\section{Mātauranga Māori: the historiographical essence of South Wairarapa Whenua}

It is paternalistic and ahistoric to claim that indigenous use of South Wairarapa natural resources did not have environmental implications. Archaeologists found that Māori burnt areas of forest and introduced exotic plants prior to European arrival. ${ }^{5}$ However, numerous scholars have suggested that Mātauranga Māori connects Tangata Whenua to the land in a way that differs profoundly from colonial capitalism's concepts of ownership and commodification. ${ }^{6}$ It dictates clear links between healthy ecosystems and people's cultural and spiritual wellbeing. ${ }^{7}$ Through whakapapa Māori are

\footnotetext{
4 Judge C.M Wainwright (presiding officer), Letter to honourable Dr Pita Sharples, Minister of Māori Affairs, 26 June, 2010, in The Wairarapa Ki Tararua Report; Volume I. p. LV.

${ }^{5}$ The Wairarapa Ki Tararua Report; Volume III. p.819.

${ }^{6}$ See: Gareth R. Harmsworth (Te Arawa, Ngāti Tūwharetoa, Ngāti Ruakawa), Shaun Awatere (Ngāti Porou), 'Indigenous Māori Knowledge and Perspectives of Ecosystems', in J.R Dymond (ed.), Ecosystem Services in New Zealand-

Conditions and Trends, Manaaki Whenua Press, Lincoln, New Zealand. pp. 274-286.

The Wairarapa Ki Tararua Report; Volume I.

The Wairarapa Ki Tararua Report; Volume II.

\& The Wairarapa Ki Tararua Report; Volume III.

${ }^{7}$ Harmsworth and Awatere, 'Indigenous Māori Knowledge and Perspectives of Ecosystems'. p.274.
} 
connected with the natural resources and landscapes of their heritage: Awa, Maunga, Marāe, and Tangata Whenua are all part of a holistic environmental balance. ${ }^{8}$ The cultural concepts of Mātauranga Māori are protected by the Tikanga: kaitiakitanga, tapu and rāhui. ${ }^{9}$ These practices sustain the mauri of natural objects, entrenching their sustainability and intergenerational equity. ${ }^{10}$ The uneasy co-existence of the cultural frameworks of Mātauranga Māori and neoliberal capitalism in New Zealand is one of the many complexities faced by the South Wairarapa community. The 2010 Waitangi Tribunal report for the Wairarapa ki Tararua region drew many conclusions similar to those drawn in other areas of this thesis, namely that legislative vagaries and disproportionate distributions of political, economic and cultural capital have continued to lead to disputes within the region. ${ }^{11}$

Drawing upon Gunter Pauli's definition of 'blue economy', Maria Bargh suggested that traditional Māori philosophy has the potential to act as an alternative to 'green' notions of sustainability. By re-establishing and creating spiritual and cultural links between people and the land, Mātauranga Māori encourages an ecological co-existence, rather than the delineating and protectionist stance delivered by green economies. ${ }^{12}$ Before in-depth discussions around discrepancies and resolutions between the worldview of Rangitāne and Ngāti Kahungunu Māori, and that of dominant neoliberal capitalism can be made, it is important to first examine some significant cultural and historical ties that South Wairarapa Iwi have to the region.

\footnotetext{
${ }^{8}$ The Wairarapa Ki Tararua Report; Volume III. p.856.

${ }^{9}$ Le Heron and Pawson, Changing Places. p.312.

${ }^{10}$ Wheen. R and Hayward. J (eds.), Treaty of Waitangi Settlements, Bridget Williams Books, Wellington, 2012. p.312.

${ }^{11}$ See, The Wairarapa Ki Tararua Report; Volume I.

The Wairarapa Ki Tararua Report Volume II.

\& The Wairarapa Ki Tararua Report Volume III.

12 Maria Bargh, 'A Blue Economy for Aotearoa New Zealand?' Environment, Development and Sustainability, Volume 6, Issue 3, June 2014, p. 459.
} 


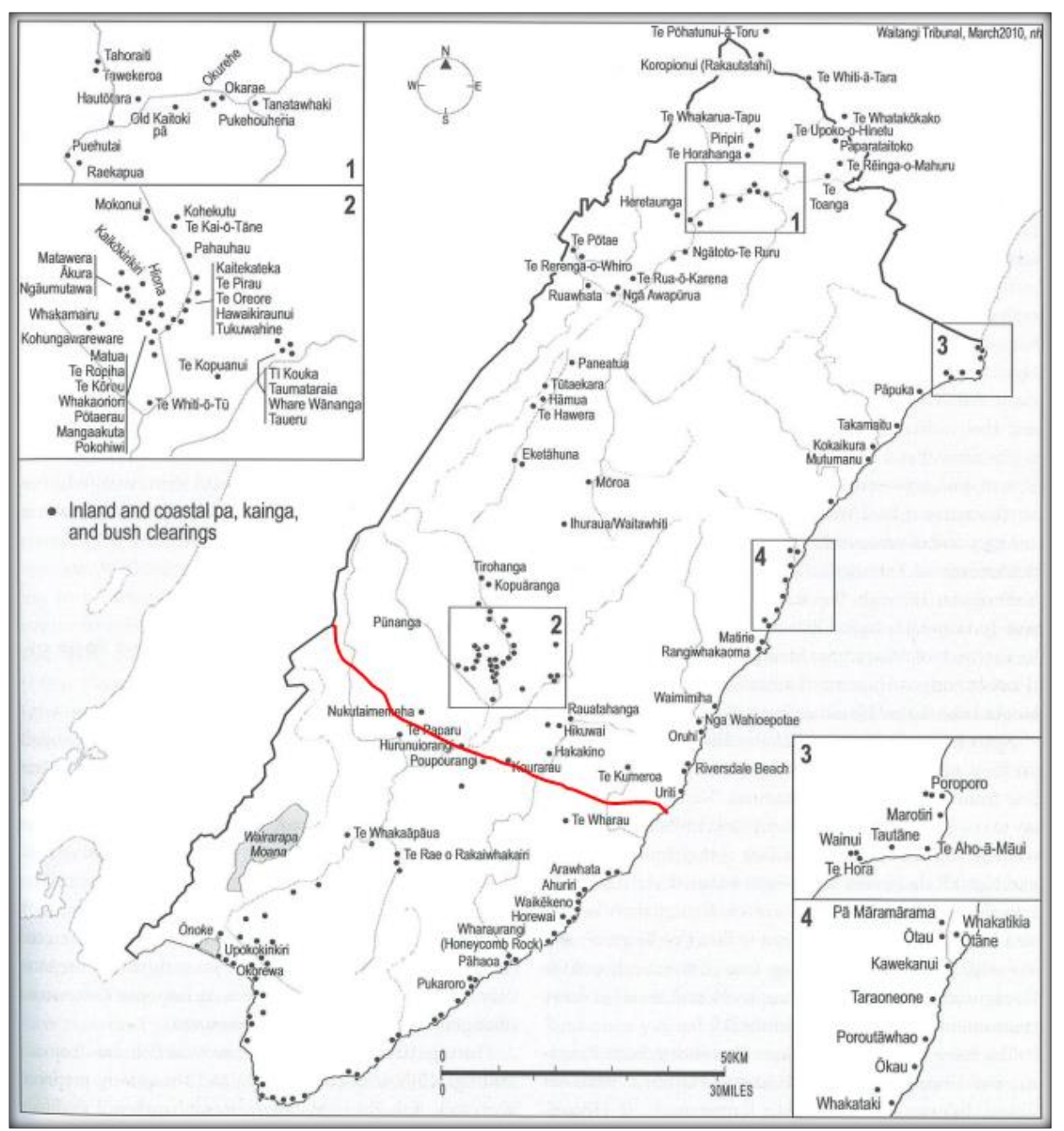

Fig $1 .^{13}$

The accompanying map showing Māori settlement between 1800 and 1840 indicates that original Kahungunu and Rangitāne settlement was densest around the coastal areas of the region. Alienation of Māori land and resources from the late nineteenth century to the present day, through purchase, public and private works, rendered many of these coastal sites inaccessible to Māori; some have been destroyed, or no longer function in accordance with tikanga. Colonial development has continually seen the coastal environment as one to be developed, drawn from and diverted. This has fundamentally affected the ability of Ngāti Kahungunu and Rangitāne Māori to exercise kaitiakitanga or maintain mana within these coastal regions. ${ }^{14}$

The Wairarapa ki Tararua Report is peppered with instances in which values concerning the development and economics of land have assumed dominance over Iwi values pertaining to the

\footnotetext{
13 'Traditional Occupation of the Inquiry District, 1800-1840s', The Wairarapa Ki Tararua Report; Volume I. p.5.

${ }^{14}$ The Wairarapa Ki Tararua Report; Volume III. p.985.
} 
coastline. The construction of the Cape Palliser coastal road in order to bolster economic infrastructure and the subsequent destruction of the Te Kōpi Urupā in 1994 is a prime example of contested opinions concerning the inherent cultural and spiritual value of the region's coast and its economic merit as a resource base for fishing, farming and tourism. ${ }^{15}$ Ngāti Hinewaka's 2001 grievance over commercial fisheries and deep sea oil drilling in their coastal waters again emphasises the discrepancy between māhinga kai, cultural, and spiritual values and the economic values apportioned by modern governments and businesses. ${ }^{16}$

The alienation of Māori land has continued up to the present day through means of private sales and the Public Works Act (1981); on the coast, there is further contestation between fundamentally distinct notions regarding the ownership of the foreshore and seabed. ${ }^{17}$ Government have asserted that Iwi's coastal land ownership ends at the high water mark, Iwi have argued that they have the right to legal ownership and kaitiakitanga of the foreshore and seabed surrounding their land blocks.

\footnotetext{
${ }^{15}$ The Wairarapa Ki Tararua Report; Volume II. p.763.

${ }^{16}$ The Wairarapa Ki Tararua Report; Volume III. p.993.

17 The Wairarapa Ki Tararua Report; Volume I. p.608.
} 


\section{Wairarapa Moana}

Fig. $2^{18}$

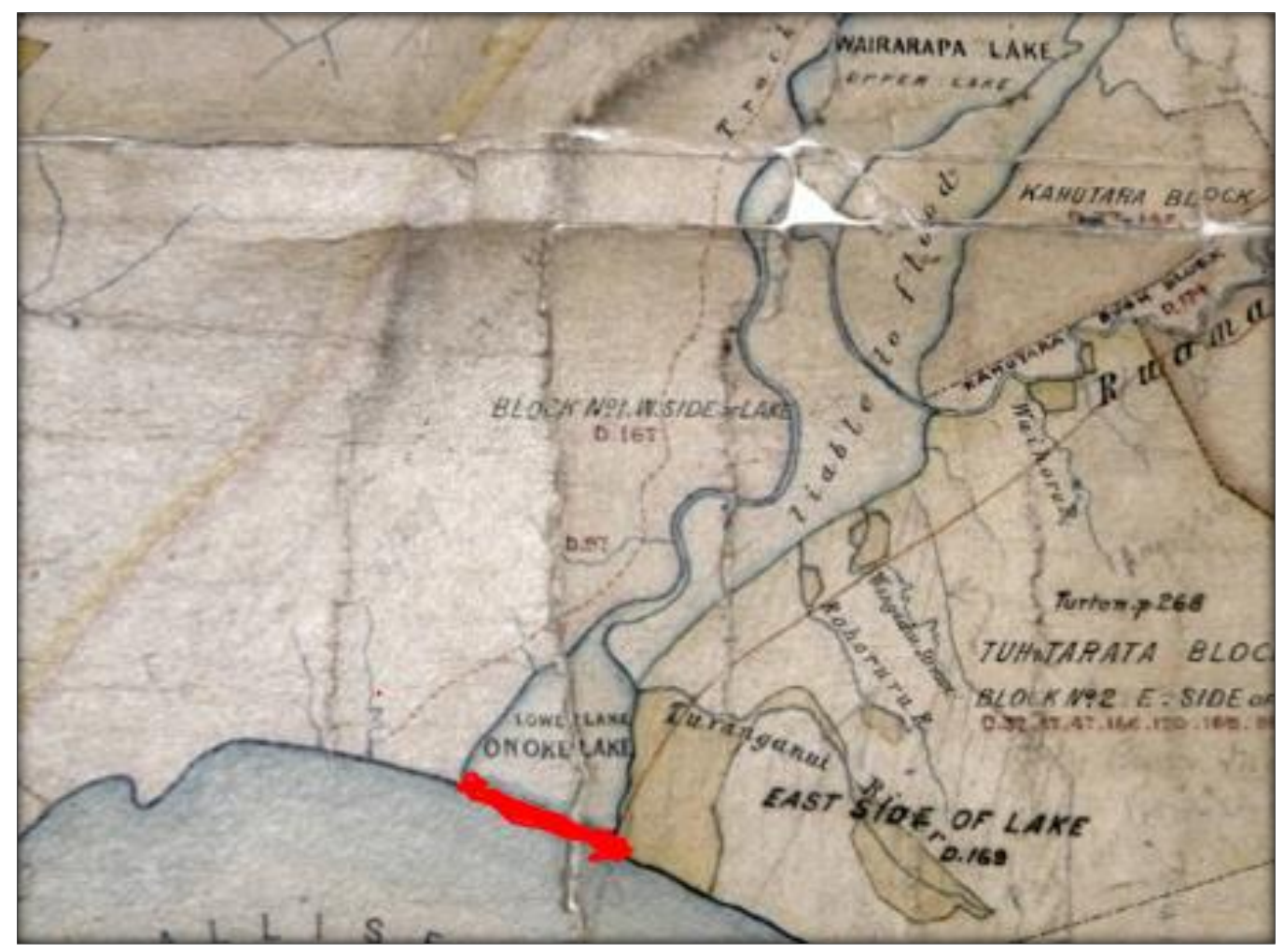

Closely linked to the South Wairarapa coastline both geographically and culturally is the land encompassing and surrounding the Wairarapa Moana. Up until the latter two decades of the nineteenth century, the lakes had acted as the liver of the region aided by the flow of the Ruamāhanga River. ${ }^{19}$ The lower lake (Ōnoke) was separated from Kawakawa Bay by Ōnoke Spit, which opened naturally throughout the year enabling the lakes, and by extension the Ruamāhanga River, to flow out to the Coast. ${ }^{20}$

While the natural flood cycle of Wairarapa Moana was economically and culturally important for Tangata Whenua, Pākehā settlers desired the flat, fertile land adjacent to the lakes for pasture. ${ }^{21}$ Tension over the future of the wetlands and lake began to mount between Rangatira and Pākehā settlers in the last decades of the nineteenth century. In 1888 the government ignored Māori protests and artificially opened the lake mouth for the first time, this continued into the 1890s

\footnotetext{
${ }^{18}$ The Wairarapa Archives, '1855 map of Wairarapa Moana', http://www.wairarapamoana.org.nz/page75848.html. (accessed 1/02/2017).

${ }^{19}$ Eleanor Rainford, Interview with Paora Ammunson.

${ }^{20}$ The Wairarapa Ki Tararua Report. p.1.

${ }^{21}$ The Wairarapa Ki Tararua Report. p.653.
} 
culminating in the 1892 'Battle of the Lakes', in which local Māori attempted to physically avert the opening. $^{22}$

The 1869 Pouākani exchange in which Wairarapa Moana was 'gifted' to the crown in exchange for land north of Lake Taūpo, far outside the rohe of both Rangitāne and Ngāti Kahungunu, remains a contentious issue. While it is outside the scope of this thesis to re-address the conflict surrounding this aspect of the Wairarapa Moana in any great historical detail, that the Pouākani land block continues to lie so far from the confines of both the Ngāti Kahungunu rohe and the South Wairarapa requires ongoing consideration.

Alienation from the lake which was a critical part of life for Kahungunu and Rangitāne Māori is the background context of recent efforts to restore the connection between Tangata Whenua and the wetlands. Paora Ammunson identified that the disconnect between Māori and the lake had grown to the extent that it had become 'like some kind of Victorian cousin down the hall suffering from insanity, that we'd locked the door and hoped that no-one noticed them there. ${ }^{23}$

The drainage of the Wairarapa Moana, re-routing of the Ruamāhanga River, increased agricultural run-off and commercial fishing of the lake throughout the twentieth century, shows not only a physical transformation of land but also a cultural transformation of the land. Natural ecosystems harnessed by Māori were manipulated for financial gain by settlers with greater political and economic capital. ${ }^{24}$ As Brooking and Pawson argued 'swamp drainage as history, is to an ecologist, a process by which a thriving, powerful expansionist culture learns how to wring wealth from a certain kind of country by cleverness and industry. ${ }^{25}$

\footnotetext{
22 'Waitangi Tribunal Report: Volume 2: The Struggle for Control, Wairarapa Moana Timeline 1840-2002', Wairarapa Moana Incorporation Waitangi Tribunal Treaty Claim: WAl 85. http://www.wairarapamoana.org.nz/page75857.html. (accessed 07/02/2017).

${ }^{23}$ Rainford, Interview with Paora Ammunson.

${ }^{24}$ Forster, 'Recovering our ancestral landscapes: A wetlands story'. p.200.

${ }^{25}$ Brooking and Pawson, Making a new land. p.182.

See also, Geoff Park, Nga uruora; ecology and history in a New Zealand landscape, Victoria University Press, Wellington, 1995.
} 


\section{Ruamāhanga Awa}

Fig.3: ${ }^{26}$

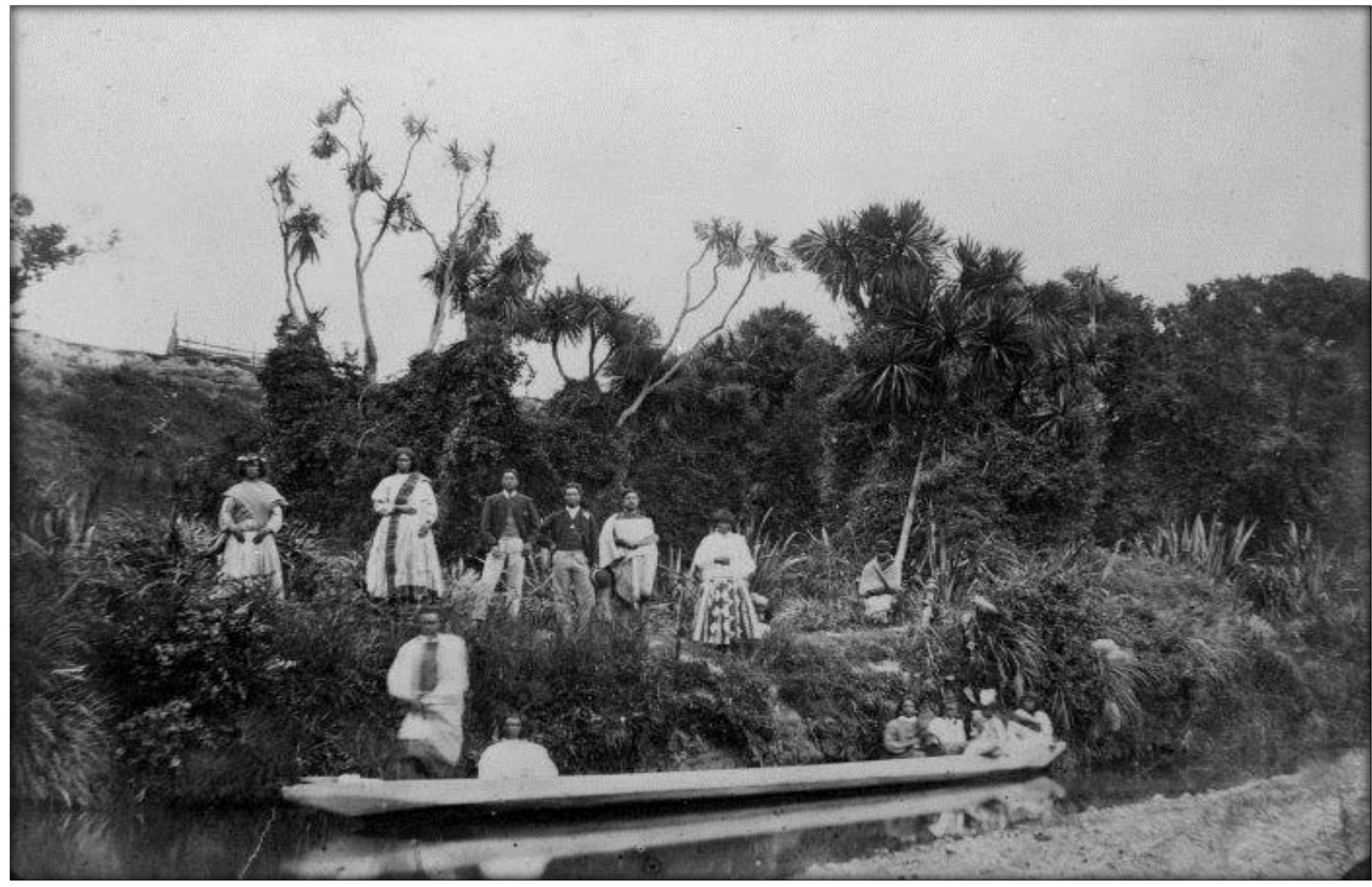

As the most significant awa of the region, the Ruamāhanga, is of immense cultural and spiritual significance to Ngāti Kahungunu and Rangitāne people. Yet half of the river, including its source and many tributaries, lie outside of the act mandated boundaries of the SWDC.

Topographically the South Wairarapa is a region supplied by water that cascades down from the Tararua ranges through a network of streams and rivers, which feed into the Ruamāhanga and flow out to the coast. ${ }^{27}$ For early Māori settlers the Ruamāhanga and its tributaries were immensely important resources for the gathering of māhinga kai and fresh water. ${ }^{28}$ The network of rivers served as a transport route, not simply for waka but as the migration pathways of valued species such as the tuna kuwharuwharu.

It is the harmony between the Māori notion of ki uta ki tai and the physical needs of native species which underlies many arguments for a 'blue ecology'. Mātauranga Māori links Māori to ecosystems

\footnotetext{
${ }^{26}$ Alexander Turnbull Library, Maori group on the Ruamahanga River, Wairarapa, [1870s-1880s], Reference Number: 1/2-107060, http://mp.natlib.govt.nz/detail/?id=8252\&l=mi. (accessed 07/02/2017).

${ }^{27}$ Rainford, Interview with Paora Ammunson.

${ }^{28}$ Brooking and Pawson, Making a new land. p.182.
} 
in a way that is mutually inclusive. ${ }^{29}$ Such observations are particularly pertinent to discussions of the ecological health of the Ruamāhanga River and the Wairarapa Moana. Kaumātua told the Wairarapa ki Tararua tribunal that prior to the diversion of the Ruamāhanga River the streams had been alive with kai and free from algae and sediment: 'You can't get kai from the river any more. People take gravel from the lands without compensating the owners. There used to be young rivers that were a source of food for our whanau. Drains have covered them up.....farmers have ploughed over, it's a hazard and now there's nothing. No swimming, nothing you can use to make kai. ${ }^{30}$

The diversion of the Ruamāhanga River away from Wairarapa Moana was cited in the Wairarapa ki Tararua Report as one of the most drastic changes to the landscape carried out by British settlement. ${ }^{31}$ Water all along the line has worsened and concerns have been raised about persistent low water tables for the Ruamāhanga River. ${ }^{32}$ The warmer nature of shallow water stimulates excessive algal growth, threatens fragile ecosystems, and negatively impacts upon the spiritual connection between Tangata Whenua and their awa. ${ }^{33}$

These issues are further exacerbated by the power dynamic between spiritual, cultural and ecological values of freshwater and the lucrativeness of the region's rivers as resources for urban development, agriculture, viticulture and horticulture industries. All of the townships in the South Wairarapa discharge partly treated effluent into the region's rivers, adding to industry contamination discussed in chapter one. ${ }^{34}$ The inability of Māori to act as kaitiaki over their most precious resources shows the extent to which political, cultural and social values of Rangitāne and Kahungunu Māori have been swept under the rug in the face of European settlement and corporate interest.

\footnotetext{
${ }^{29}$ Harmsworth and Awatere, 'Indigenous Māori Knowledge and Perspectives of Ecosystems'. p.274.

30 The Wairarapa Ki Tararua Report; Volume III. p.849.

31 ibid. p.851.

32 Rainford, Interview with Paora Ammunson.

${ }^{33}$ Royal, Cultural Values for Wairarapa Waterways. p. 28.

${ }^{34}$ The Wairarapa Ki Tararua Report; Volume III. p.851.
} 


\section{Wāhi tapu sites and public works}

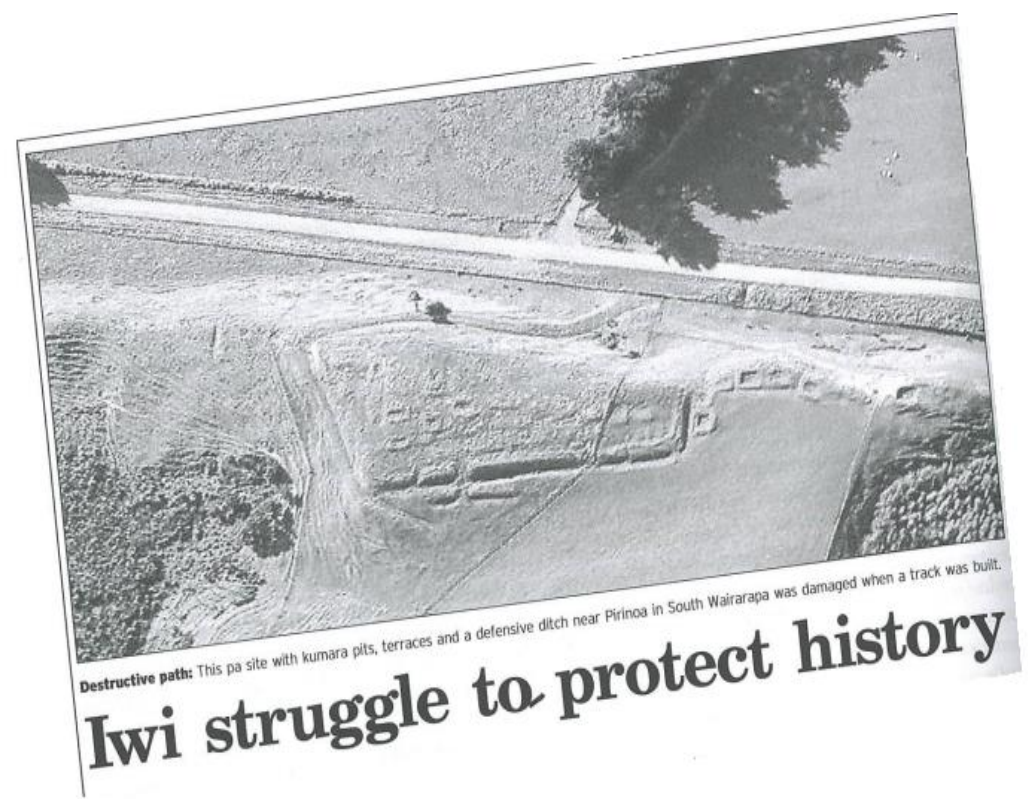

Fig.4. ${ }^{35}$

The predominance of Western cultural and political capital over Māori cultural and political capital is equally prevalent with regard to how the protection of wāhi tapu sites is approached. The accompanying newspaper clipping from 2008 depicts a historic pa site at Tora Bay on the East Coast of the South Wairarapa. In the image's accompanying article historian Haami Te Whaiti discusses the difficulty in protecting Māori heritage sites from wholesale development. ${ }^{36}$

The difficulties experienced by South Wairarapa Māori attempting to protect their turangawaewae are twofold. In this instance, although the site was no longer owned by Māori, it was listed as a heritage site by The Historic Places Trust. ${ }^{37}$ Data suggests that registered wāhi tapu sites are frequently listed in district plans, but inclusion is discretionary. The RMA's statutory position is contradictory in practice. Section 74 of the act infers that applicants seeking to change a district plan need only pay 'regard' to relevant entries in the Historic Places Trust. Section 6 implicitly states in its 'matters of national importance', 'the protection of historic heritage from inappropriate subdivision, use and development', and the 'relationship of Māori and their culture and traditions with their ancestral lands, water, sites, wāhi tapu, and other taonga.' ${ }^{38}$

\footnotetext{
${ }^{35}$ Tanya Katterns, 'Iwi struggle to protect history', The Dominion Post, 21/8/2008. http://www.stuff.co.nz/national/682621/Iwi-struggle-to-protect-history. (accessed 02/03/2017).

36 ibid.

37 ibid.

${ }^{38}$ The Wairarapa Ki Tararua Report; Volume III. p.967.
} 
The other way in which wāhi tapu sites have been threatened is by land seizures under the Public Works Act. The Act enabled council to acquire land for the building of infrastructure such as roads, railways and lighthouses. Māori land in the South Wairarapa continues to be seized for public work, in preference to crown owned or Pākehā owned land. ${ }^{39}$ This demonstrates the prominent imbalance of political and cultural capital in the region. It is also representative of a continuation of colonial attitudes toward land use and terra nullius. Māori land, particularly that which surrounds or encompasses wāhi tapu sites, frequently does not conform to the Pākehā rubric of 'productive land use' and is therefore disproportionately acquired for public works.

The plots of land purchased and/or acquired by local council have usually been relatively small. The largest plots of Māori land taken under the Act have been those around the Palliser Bay region, concerning the building of the Palliser Bay Coastal Road and the maintenance of the Palliser Bay Lighthouse. In 1897 land was taken from the Mātakiaki reserve for the building and maintenance of a lighthouse. Tangata Whenua had to wait almost a century for the return of their land in $1993 .{ }^{40}$ In this instance the land was returned in recognition of wāhi tapu values, however this has not been the case with regard to many other sites in the region, the most primary example being the building of the Cape Palliser Coastal Road and the destruction of the Te Kōpi Urupā.

There is little to no evidence that Tangata Whenua were consulted with regard to plans of building the road in the 1930s. ${ }^{41}$ Over the ensuing decades coastal erosion determined that public works continue to be enacted for the maintenance of the road. A report by project management company Beca (2000) determined that coastal erosion had worsened during the period between 1996 and the year 2000. ${ }^{42}$ While Beca concluded that worsening coastal erosion was due to the tidal pressure upon the lose mudstone cliffs of the coastline ${ }^{43}$, research by other scholars on the causes and effects of coastal erosion suggested that hill country farming, deforestation and extensive public use all contributed to the process. ${ }^{44}$ The initial unsuitability of the coastline as a transport route actively contributed to the continued acquisition of land for public works.

\footnotetext{
${ }^{39}$ The Wairarapa Ki Tararua Report; Volume II. p.960.

${ }^{40}$ The Wairarapa Ki Tararua Report; Volume II. p.760.

41 ibid.

${ }^{42}$ Beca Carter Hollings and Ferner Ltd. (Beca), Report; South Wairarapa District Council Resource Consent Application and Assessment of Effects on Environment Coastal Protection Works, Beca, 24/4/2009. http://www.gwrc.govt.nz/assets/Resource-Consents/6379 SWDCRCApplicati s12449.pdf. (accessed 07/03/2017). 43 ibid.

${ }^{44}$ See, The Wairarapa Ki Tararua Report; Volume III.

Catherine Knight, New Zealand Rivers; An Environmental History, Canterbury University Press, 2017.
} 
The building of the Cape Palliser Coastal Road and ensuing coastal erosion has had a number of significant environmental and cultural impacts. Claimants to the Waitangi Tribunal noted that their wāhi tapu sites had been threatened by soil erosion and its detrimental effects upon land quality, flora of the region, and water cleanliness. Also posing a threat to sites of cultural significance was pollution and the lighting of illegal campfires consequent of increased public access to the area. ${ }^{45}$ Most significantly, ongoing requirements for the road to be strengthened and structured threatened surrounding wāhi tapu sites. Despite a 1994 engineers report identifying the Te Kōpi Urupā as 'the most apparent evidence of wāhi tapu', council continued the roadworks. ${ }^{46}$

The lack of consultation with Tangata Whenua over the construction of the Cape Palliser Coastal Road is unsurprising, given the race-relations climate of the 1930s. However, the continuation of the acquisition of Māori land, including that which encompasses wāhi tapu sites- for public works throughout the twentieth century and into the twenty-first century, necessitates discussion of the willing ignorance of Māori cultural and spiritual values by infrastructural development.

\section{Changing face? Legislative reform and its implications for Tangata Whenua}

There is general consensus that the 1980s introduced a number of legislative changes with regard to the way that land, resources and local government were managed across New Zealand. The RMA, LGA, Historic Places Act and the instantiation of DOC and the Ministry for the Environment, along with a number of smaller more specific pieces of legislation, all represented in one way or another an attempt to- at the very least- acknowledge the cultural values of Tangata Whenua. The extent to which these attempts affected any real change among Rangitāne o Wairarapa and Ngāti Kahungunu ki Wairarapa communities is in debate.

Paora Ammunson commended the process of the Wairarapa ki Tararua Waitangi Tribunal Inquiry, stating, 'There are probably forest lands that border up to the lake and up into the mountains that are part of the Treaty settlement package, so I think in the long term Iwi are the fastest evolving form of local government in New Zealand. Iwi interests will be part of every aspect of life, and they are, naturally, part of every aspect of life over here so it means that the thinkers and the leaders are realising that everything is on the verge of some sort of change. ${ }^{47}$ Ammunson's opinion represents

\footnotetext{
W. Smith, H. Montgomery, T. Rhodes, 'North Island hill country farmers' management response to issues of sustainability', New Zealand Geographer, 63, 2007. pp.30-42.

45 The Wairarapa Ki Tararua Report; Volume III. p.987.

${ }^{46}$ The Wairarapa Ki Tararua Report; Volume II. p.763.

${ }^{47}$ Rainford, Interview with Paora Ammunson.
} 
an optimistic view of the future for Kahungunu and Rangitāne Māori, grounded in changes which have occurred over the past thirty years.

Other commentators are not as complimentary of - nor optimistic about - the changes that have occurred. Tangata Whenua spokesperson and resource manager Murray Hemi voiced his frustration at current legislation in a submission to the WAI 863 report 'No legislation has ever recognised the philosophical or theological nature of our world. No legislation has ever recognised the imperative of our tino rangatiratanga, the value of mauri, or the effective expression of kaitiakitanga within its own cultural and traditional context. ${ }^{48}$ While Ammunson praises progressive political change, Hemi criticises a lack of cultural change. The following section will extend upon the earlier discussion of Mātauranga Māori and investigate the relations between key facets of māoritanga and the New Zealand legislative process since the 1984 reforms.

\section{The RMA: a step forwards or backwards?}

The Resource Management Act (1991) was devised in response to the concerns of a number of parties about how the nation's land and resources were managed. To many intents and purposes the Act appeared progressive in regard to Māori and Crown relations. Māori had been consulted in its drafting process during the 1980s, and some understanding of kaitiakitanga was incorporated into the finished legislation. ${ }^{49}$ Prior to amendment, section 6(e) of the RMA declared the relationship of Māori and their culture and traditions with their ancestral lands, water, sites, wāhi tapu, and other taonga', to be a matter of national importance. ${ }^{50}$ Formally amended to these matters in 2003 and 2008 were sections $6(\mathrm{f})$ and $6(\mathrm{~g})$, the protection of historic heritage from inappropriate subdivision, use, and development, and the protection of protected customary rights. ${ }^{51}$ Section $7(a)$ and 8 state that all persons exercising management functions over the development and protection of natural and physical resources must give particular regard to kaitiakitanga and to the Treaty of Waitangi. ${ }^{52}$

These provisions on paper were a step forward from what had previously been a complete lack of regard for māoritanga in resource planning and environmental management, but in practice their application and adherence has been chequered: 'The Waitangi Tribunal has repeatedly found that

\footnotetext{
${ }^{48}$ The Wairarapa Ki Tararua Report; Volume III. p.891.

49 ibid. p.858.

${ }^{50}$ Resource Management Act 1991; Reprint as at 13 December 2016, Public Act 1991, No.16, Part 2, Section 6. p.58.

51 ibid.

${ }^{52}$ Resource Management Act 991; Reprint as at 13 December 2016, Public Act 1991, No.16, Part 2, Section 7 and Section 8. pp.59-60.
} 
the RMA, and the ways in which it is implemented do not provide fairly for Māori interests, nor is the legislation in accordance with Treaty principles. ${ }^{53}$ The reasons for the Acts' disservice towards Tangata Whenua are in many ways a continuation of the themes of imbalances of cultural, political and economic capital, and semantic and legislative vagueness discussed elsewhere in this thesis.

The 1992 LGA rested the responsibility of enacting the RMA with regional councils. Accordingly, the GWRC became responsible for not only resource management in the South Wairarapa, but also in the Carterton and Masterton Districts, Kapiti Coast and Central Wellington District. Yet consultation with Tangata Whenua, particularly with regard to resource concerns, primarily occurred on a local level. This had a tendency to exclude Tangata Whenua from the decision making process by distancing them from those who held the final say. ${ }^{54}$ Both the Waitangi Tribunal and scholars such as Harry Allen concluded that the Treaty of Waitangi and Tangata Whenua are not appropriately acknowledged by the LGA. ${ }^{55}$ Consequently, consultation with Tangata Whenua with regard to the RMA is either evaded or treated in the same manner as consultation with lobby or interest groups. ${ }^{56}$

The SWDC is the most culturally diverse local council in the country, two of the ten councillors currently identify as Tangata Whenua: Pip Maynard and Paora Ammunson. This has undeniably had a positive influence on Tangata Whenua-Council relations, some of which will be discussed later in this chapter; however, Māori representation in the local governance of the region is historically poor. ${ }^{57}$ Ammunson suggests that the current above average representation of Māori on the council may be due to the public profiles of himself and Maynard outside of simple Iwi connections. ${ }^{58}$ The 1985 establishment of the Māori Standing Committees represented a link for discussion between Council and Tangata Whenua, yet they exist in an advisory role rather than one of active governance. ${ }^{59}$

The other primary concern with regard to the RMA and its responsibility toward Tangata Whenua lies once again in legislative semantics and translation. Lorraine Stephenson appointed by Rangitāne-o-Tāmaki-nui-ā-Rua to manage government, conservation and resource management

\footnotetext{
${ }^{53}$ The Wairarapa Ki Tararua Report; Volume III. p.898.

54 ibid.

${ }^{55}$ See, The Wairarapa Ki Tararua Report; Volume III.

\& Harry Allen, 'Community and the reform of local government in New Zealand', Social Analysis: The International Journal of Social and Cultural Practice, Vol 43, No.2, Backwaters run deep: Locating New Zealand Social Anthropology, July 1999. pp.70-87.

${ }^{56}$ Allen, 'Community and the reform of local government in New Zealand'. p.73.

57 The Wairarapa Ki Tararua Report; Volume III. p.887.

${ }^{58}$ Rainford, Interview with Paora Ammunson.

${ }^{59}$ The Wairarapa Ki Tararua Report; Volume III. p.888.
} 
portfolios echoed the sentiments of Murray Hemi in his submission to the Waitangi Tribunal: 'The traditional institution of kaitiaki does not stand alone, it is part of a complex social, cultural, economic and spiritual system that has been established through long tribal association with land and waters. To know kaitiaki is to know the Māori world - the tribal structures of iwi, hapū, whānau, Tangata Whenua, manawhenua, ahi kaa, kaumātua, kuia, tohunga and whanaunga. These make up a dynamic and thriving community. These all characterise Wairarapa Māori today. ${ }^{60}$

When consulting the terms with which Tangata Whenua are acknowledged in the RMA it is evident that there is a fundamental disconnect between the point of view expressed in the legislation and the traditional Māori world view. Regard cannot be given to kaitiakitanga when Tangata Whenua have little to no control over the final decision making processes regarding natural and physical resources. As Caleb Royal identifies in his report Cultural Values for Wairarapa Waterways, the RMA translates Kaitiakitanga as 'guardianship' or 'stewardship'. The 1997 amendment of section 7 (aa) 'the ethic of stewardship' is a further misinterpretation of the holistic Māori world view and its kaupapa. ${ }^{61}$

While sections of the RMA may imply an attempt to involve Tangata Whenua in resource and land management, the legislation is problematic in action. While it does suggest a political shift toward the engagement of Māori with their Turangawaewae, it is at worst a false promise, and at best a fundamental misunderstanding of the kaupapa of the Māori world view. The legislation is further complicated by bureaucratic hurdles instated by the LGA, which made access to the political decision making process more difficult. The optimism of Ammunson in this context may be explainable by his proximity to the decision making process, as a member of the District Council, however the testimony of Hemi and the conclusions of the Wairarapa ki Tararua Report suggest that for the majority of South Wairarapa Māori the RMA has been inefficient in recognising their political, cultural and economic needs.

\section{Protecting the wairua of wai: water under the bridge?}

Over the past thirty years the majority of efforts at cultural redress to Ngāti Kahungunu and Rangitāne o Wairarapa have been in relation to water. This is unsurprising given the number of water related grievances that Tangata Whenua presented to the Waitangi Tribunal. It is significant that while Pākehā continue to emphasise the value of land, South Wairarapa Māori are increasingly

\footnotetext{
60 The Wairarapa Ki Tararua Report; Volume III. p.903.

${ }^{61}$ Royal, Cultural Values for Wairarapa Waterways. p.11
} 
concerned with the value of water. European focus on land and its value may explain why water management has been a key sight of cultural redress over the past thirty years. These attempts have had mixed success. A number have failed to take into account the disadvantage that Tangata Whenua face as a political and cultural minority. Where initiatives have succeeded, agricultural land use and misinterpretations of māoritanga by involved governance bodies are still an issue. The following section will address these initiatives, as well as the contemporary issues that have arisen over the past thirty years.

\section{Tuaone and Tahuaroa}

One of the pieces of legislation most ardently opposed by Tangata Whenua in recent years was the Foreshore and Seabed Act (2004). Like many other claims heard in the Wairarapa ki Tararua Inquiry, grievances surrounding the Act had a significantly longer history than contemporary legislation suggests. While this piece of legislation was particularly controversial, claimants identified that it was the result of a culmination of pieces of legislation that had historically failed to recognise Māori customary ownership of both the foreshore and seabed. ${ }^{62}$

Section 7 of the Territorial Sea and Exclusive Economic Zone Act (1977) vested the ability to grant and renew fishing licences and the ownership of the New Zealand territorial seabed with the Crown. The Act served to 'make provision with respect to the territorial sea and the contiguous zone of New Zealand; and to establish an exclusive economic zone of New Zealand adjacent to the territorial sea, and in the exercise of the sovereign rights of New Zealand to make provision for the exploration and exploitation, and conservation and management, of the resources of the zone; and for matters connected with those purposes. ${ }^{63}$ It is evident that the 'exercise of sovereign rights' referred not to Māori sovereignty or Rangatiratanga, but to that of the Crown.

In 1982 the Muldoon Government imposed a moratorium on new entrants to the fishing industry while experts investigated the cause and extent of declining fish stocks. The outcome was the passing of the Fisheries Act (1983). ${ }^{64}$ The definition of commercial fishermen within the Act excluded many small-scale Māori fisheries, denying them access to their customary fisheries. ${ }^{65}$ The Act was amended in 1986 to introduce full quota management systems to New Zealand, which put limits on the total allowable catch for each quota management area. Māori part time fishermen were again

\footnotetext{
62 The Wairarapa Ki Tararua Report; Volume III. p.123.

${ }^{63}$ Territorial Sea, Contiguous Zone, and Exclusive Economic Zone Act, (Commencement Amended 1996), Reprint as at 15th December 2005, 1977, Public Act 1977, No.28, 26/09/1977, Part.2, Section 15 \& 16. p.16.

${ }^{64}$ Brian Bargh, The Struggle for Māori Fishing Rights; Te Ika A Māori, Huia Publishers, Wellington, 2016. p.55.

65 ibid. p.57.
} 
excluded from commercial permits. ${ }^{66}$ In 1987 the High Court placed an injunction on the quota management system in response to the findings of the Waitangi Tribunal Ngai Tahu Inquiry. ${ }^{67} \mathrm{~A}$ joint Crown-Māori working party failed to reach a resolution and associate Finance Minister Richard Prebble took over negotiations with Māori. ${ }^{68}$ In September 1988 a resolution was reached and the Māori Fisheries Bill was introduced to Parliament. ${ }^{69}$

The Māori Fisheries Act (1989) introduced taiāpure as a means of transferring ten percent of the national fishing quota to Māori. Historian and Author Mita Carter petitioned for six taiāpure to be instated in the South Wairarapa, five on the coast and one encompassing Lake Ōnoke. ${ }^{70}$ Despite the cooperation of the DOC and the Ministry of Fisheries, the process of securing the taiāpure was thwarted by conflicts of interest from commercial fishermen in the region and internal struggles between hapū. ${ }^{71}$

When finally approved in 1995 the taiāpure encompassed only a minute proportion of the customary fisheries of Ngāti Hinewaka. The fishery neither provided enough resources for the hapū, nor protected other significant areas of the coastline from overfishing. ${ }^{72}$ Haami Te Whaiti stated 'the management committee has no teeth with which to enforce the taiāpure or change it as needed. In order to change any part of the taiāpure the committee must lobby the minister, must go through a public process, and then any changes can only be implemented by way of regulation... The fact that we receive no support or resources to undertake these processes is indicative of the Crown's poor commitment to the implementation of these regulations. ${ }^{73}$

The Fisheries regulations introduced in 1998 enabled Māori to create protected mātaitai reserves. Yet once again the processes necessary to instate such a reserve were difficult. The appointment of one Kaitiaki as the liaison between the rohe moana, Tangata Whenua and Council, both overlooked the inherent responsibility of kaitiakitanga in all Tangata Whenua, and created conflict between Hapū and Iwi who shared customary rights. ${ }^{74}$ Once appointed, the Kaitiaki did not have access to any legislative powers and was once again relegated to little more than an advisory position. ${ }^{75}$ The

\footnotetext{
66 ibid. p.58.

67 ibid. p.66.

68 ibid. p.73

69 ibid. p.74.

${ }^{70}$ The Wairarapa Ki Tararua Report; Volume III. p.994.

71 ibid. pp.996-997.

72 ibid. p.998.

73 ibid. p.1008.

${ }^{74}$ The Wairarapa Ki Tararua Report; Volume III. p.1012.

75 ibid. p.1011.
} 
Wairarapa ki Tararua Report is inconclusive about why no mātaitai reserves have been applied for in the South Wairarapa region. However, the historical failure of the Taiāpure venture, the difficulty of appointing a Kaitiaki, and the lack of legislative power enabled by the regulations are all possible reasons for the lack of engagement.

In 1997 the Māori Land Court (MLC) ruled that customary ownership of the foreshore and seabed in the Marlborough Sounds had not been subject to a 'blanket extinguishment' by the legislation of the 1970s. ${ }^{76}$ The Crown appealed this ruling to the Appellate Court, which in turn referred the case to the High Court. In June 2001 it was declared that the MLC had jurisdiction to determine whether the foreshore was Māori customary land, but not the seabed; this decision was appealed. ${ }^{77}$ In 2002 a number of tribes throughout New Zealand, with the support of the original claimant group, Te Tau Ihu o te Waka (Tribes at the top of the South Island), challenged the Crown's quota management system. ${ }^{78}$ The dispute over water title was now becoming a national issue. In June 2003 the Court of Appeal ruled that the MLC did have jurisdiction to declare that the seabed was Māori customary land. ${ }^{79}$ The Labour Government opposed the ruling, announcing its intention to pass legislation preventing the ability of the MLC to issue freehold title to foreshore and seabed areas.

It is interesting that it was not until the debates surrounding the Foreshore and Seabed Act that the question of 'ownership' of the seabed was raised. While this question requires further research there are a number of plausible reasons for this. Discussion of the fundamental difference between Māori and Western concepts of 'ownership' may have been deemed implausible until the Treaty of Waitangi Settlement Act (1992) set out Crown obligations relating to commercial fisheries, particularly the allocation of quota to Māori. ${ }^{80}$ The delaying of the question was likely to have been magnified in the South Wairarapa due to the lack of success experienced through other legislative channels. Finally, increased damage done to Māori land and rohe moana by increased settlement, commercial and recreational use of the South Wairarapa Coast throughout the 1980s and 1990s may have spurred Iwi into action.

Debates surrounding the Foreshore and Seabed Act were once again primarily grounded in the fundamental difference between the Māori and Western worldview. On the one hand the struggle was again semantic: 'foreshore' and 'seabed' represented two distinct areas in legislation but for

\footnotetext{
${ }^{76}$ Bargh, The Struggle for Māori Fishing Rights. p.157.

77 ibid.

78 ibid. p.159.

79 ibid.

${ }^{80}$ Le Heron and Pawson, Changing Places. p.154.
} 
Tangata Whenua the two areas were part of an unsurmountable whole. ${ }^{81}$ On the other hand it represented another example of a dispute over land and resource allocation. While the Crown asserted ownership and resource rights of all area below the low water mark, Ngāti Hinewaka me ōna Kārangaranga asserted a 'blue-water title' over the foreshore and seabed bordering their land. ${ }^{82}$ In addition to concerns over increased public use of the foreshore, overfishing and loss of mana, the Wairarapa ki Tararua Inquiry investigated a proposal which allowed AMCO NZ to carry out offshore drilling for oil exploration. ${ }^{83}$

The Foreshore and Seabed Act has continued to be contentious. The focus on customary fishing rights has been somewhat alleviated by the granting of Māori fishing quotas in the region and Ngāti Kahungunu's 2014 fishing deal with commercial giant Sealord, which provided the Iwi with lucrative economic prospects. ${ }^{84}$ The other major contestation to emerge in the twenty-first century has been the increased desire of government to increase oil exploration in New Zealand territorial waters and on Māori land; these debates are ongoing.

The Confidence-and-Supply Agreement (2009) between the National Government and the Māori Party saw the repeal of the Foreshore and Seabed Act (2004); it was replaced by the Marine and Coastal Area (Takutai Moana) Act (2011). Changes to legislation were primarily semantic, removing the 'ownership' of the seabed from the Crown and instating a 'no ownership' regime. ${ }^{85}$ However, there was little marked change in Government recognition of the customary rights of Tangata Whenua with regard to their coastal rohe. The corporate interest behind the Territorial Sea and Exclusive Economic Zone Act (1977) remains evident in modern day government efforts to secure territorial coastal waters for fracking purposes. Attempts by the Fourth Labour Government to develop legislation enabling Māori to protect, develop, and utilise their rohe moana were insufficient at best, and empty at worst. For South Wairarapa Māori seeking to protect and reclaim their rohe moana the period from 1984 to the present day has been characterised by frustration, false promises and un-actable legislation.

\footnotetext{
${ }^{81}$ Tracy Whare, 'The Foreshore and Seabed Act: Five Years on, where to from here', Māori and the Environment: Kaitiaki, Rachel Selby, Pātaka Moore and Malcolm Mulholland (eds.), Huia Publishers, Wellington, 2010.p.59.

82 The Wairarapa Ki Tararua Report; Volume III. p.1024.

83 ibid.

${ }^{84}$ Ngāti Kahungunu Iwi Inc., 'Press Release: Ngāti Kahungunu and Sealord Announce Fishing Deal', Scoop Independent News, 3/06/2014. http://www.scoop.co.nz/stories/BU1406/S00031/ngati-kahungunu-and-sealord-announce-fishingdeal.htm. (accessed 15/12/2016).

${ }^{85}$ Bargh, The Struggle for Māori Fishing Rights. p.184.
} 


\section{Wairarapa Moana}

The Wairarapa ki Tararua Report stated that 'too many years have passed since the enormous wetland around Wairarapa Moana was lost for the current generation of Wairarapa Māori to be able to give direct evidence about the effects of its loss to Tangata Whenua. ${ }^{\prime 86}$ Despite this generational distance, the management and control of the Wairarapa Moana has been one of the key areas of successful redress over the past thirty years. Although the Lakes will never be returned to their nineteenth-century state, the actions of government, council and Iwi have fostered a mutual contract with regard to the spiritual, cultural and ecological value of the lake. ${ }^{87}$

The initial interest in the restoration and protection of the Wairarapa Moana had little to do with Tangata Whenua. The Water and Soil Conservation Act (1967) was explicit about the natural character of waterways and the regulation of water resource use; however, the Act also declared, as was customary for the time, that all water belonged to the Crown. ${ }^{88}$ There was no acknowledgement of the cultural, spiritual or ecological significance of water for Māori, and there was no consultation with Tangata Whenua during the drafting of the legislation. ${ }^{89}$

In 1987 The Wairarapa Moana Trust was established by the Pou-a-kani II Trust and the Mangakino Township as a vehicle for cultural, economic and social development of the beneficiaries of the land at Pouākani, which as we have seen was exchanged for land surrounding the Wairarapa Moana in 1869..$^{90}$ In March of the 1987 John Hanita Paki, on behalf of himself, the trustees and the beneficial owners of the lands in the Titiraupenga and Pouākani B9B Trust, filed WAI 33 (The Pouākani Report). ${ }^{91}$ Interestingly, it was the proceedings of the Waitangi Tribunal that would re-establish the historic link between Ngāti Kahungunu ki Pouākani Māori, Ngāti Kahungunu ki Wairarapa Māori, and by extension the Wairarapa Moana. The Tribunal requested that grievances pertaining to Ngāti Kahungunu ki Pouākani and the 'Wairarapa Exchange' be investigated in the context of Ngāti Kahungunu ki Wairarapa interests. ${ }^{92}$ Kingi Winiata Smiler's statement of claim (WAI 85, 2003)

\footnotetext{
${ }^{86}$ The Wairarapa Ki Tararua Report; Volume III. p.848.

${ }^{87}$ Ngāti Kahungunu Ki Wairarapa Tāmaki nui ā Rua and The Crown, Agreement in Principle to Settle Historical Claims, 07/05/2016. p.20.

${ }^{88}$ Knight, New Zealand's Rivers. p.86.

${ }^{89}$ The Wairarapa Ki Tararua Report; Volume III. p.843.

${ }^{90}$ Wairarapa Moana Incorporation, Wairarapa Moana Trust; Distributing to the shareholders, beneficiaries and their descendants the benefits accrued... http://www.wairarapamoana.org.nz/page133387.html. (accessed 01/03/2017).

91 The Pouakani Report, Waitangi Tribunal Report, 1993, WAI 33, Chapter 1, 1.1, p.1.

92 The Pouakani Report, Waitangi Tribunal Report, 1993, WAI 33, Chapter 17, 17.1, p.327.
} 
became part of the basis informing the Wairarapa Moana section of the Wairarapa Ki Tararua Report. ${ }^{93}$

The actions of John Hanita Paki and Kingi Winiata Smiler were fundamental to late twentieth and twenty-first century actions toward the repatriation and reparation of the Wairarapa Moana. Their claims functioned as political instigators of a change in attitude from Wairarapa Iwi, SWDC, GWRC and DOC. Paora Ammunson noted that in the early twenty-first century the Ngāti Kahungunu ki Wairarapa Committee resolved that the alienation of Kahungunu people from their ancestral lake needed to be rectified. ${ }^{94}$ Ammunson credits the Waitangi Tribunal claims process, and the relationship between the Kahungunu committee and the GWRC, for the early development of a Wairarapa Moana action plan: 'as an Iwi leader I would often find myself at meetings with people like Fran Wilde, who at the time was the chairwoman of the Wellington Regional Council... She personally recognised with enough support from her councillors that eventually the treaty settlement process would result in some sort of statutorily mandated group or entity over the lake. So we could see that coming down the road at us in 2003 and it's all about to happen in 2016. We resolved to work together, we thought, we may as well not wait until 2016. We didn't have any idea when it would happen so we thought we may as well set the ball rolling. ${ }^{95}$

The collaboration between Iwi and high level governance groups has continued into the second decade of the twenty-first century. Iwi continue to liaise with local, regional and national government on the management of the Wairarapa Moana to varying degrees of success. DOC was responsible for the proposal and implementation of a water conservation order for the lake, an important step in the protection of māhinga kai and wāhi tapu. The Department also worked closely with Ngāti Kahungunu on the Lake Wairarapa Wetlands Action Plan 2000-2010, in which Tangata Whenua were given opportunities to exercise their role as kaitiaki in decision making and management roles. The plan calls for Iwi and Hapū, as kaitiaki of the area, to be involved in any decision that has potential effects on the lake's wetlands. ${ }^{96}$

The predictions of Ammunson, Wilde and other Iwi and Regional Council members were echoed in the Ngāti Kahungunu Ki Wairarapa Tāmaki nui ā Rua and The Crown, Agreement in Principle to Settle Historical Claims (2016). The establishment of a Wairarapa Moana Statutory Board consisting

\footnotetext{
${ }^{93}$ Wairarapa Moana, Wairarapa Moana Incorporation Waitangi Tribunal Claim, WAI 85, http://wairarapamoana.org.nz/page75857.html. (accessed 28/11/2016).

94 Rainford, Interview with Paora Ammunson.

95 ibid.

${ }^{96}$ The Wairarapa Ki Tararua Report; Volume III. p.931.
} 
of representatives of Ngāti Kahungunu ki Wairarapa, Rangitāne o Wairarapa and Rangitāne Tāmaki Nui-ā-Rua placed the guardianship of the Wairarapa Moana and its resources in the hands of Iwi members selected by high level governance groups. ${ }^{97}$ The board is responsible for the administration, maintenance and control of the lake's reserves, the management of conservation areas, and the promotion of the restoration, protection and enhancement of the social, economic, cultural, environmental, spiritual health and wellbeing of the lake. ${ }^{98}$

The Waitangi Tribunal process and the establishment of the Wairarapa Moana Statutory board has marked a significant shift toward reconnecting Tangata Whenua with Wairarapa Moana, restoring some of the mana that was lost, remembering the whanaungatanga of the lake and reinstating the ability of Tangata Whenua to exercise kaitiakitanga over one of the region's most important ancestral landscapes. ${ }^{99}$ The redress is in its early stages, it remains to be seen how obstacles such as agricultural and industrial pollution can be overcome by the Statutory Board. These are effects with origins further up the Ruamāhanga River catchment and often derive from private farm land and industry, which lie beyond the jurisdiction of the Statutory Board and local council. It is unlikely that the freshwater ecology of the lake can be significantly improved without rigid water quality control in North Wairarapa. Despite the ecological complexities surrounding the management of the lake, the development of the Wairarapa Moana Statutory Board and the privileged role given to Tangata Whenua in the management of the lake and its resources has been a major cultural and political accomplishment of the past 30 years.

\footnotetext{
${ }^{97}$ Ngāti Kahungunu Ki Wairarapa Tāmaki nui ā Rua and The Crown, Agreement in Principle to Settle Historical Claims. p.17.

98 ibid.

${ }^{99}$ Forster, 'Recovering our ancestral landscapes: A Wetlands story'. p.207.
} 
Fig.5 The Progression of the Wairarapa Moana Claims Process

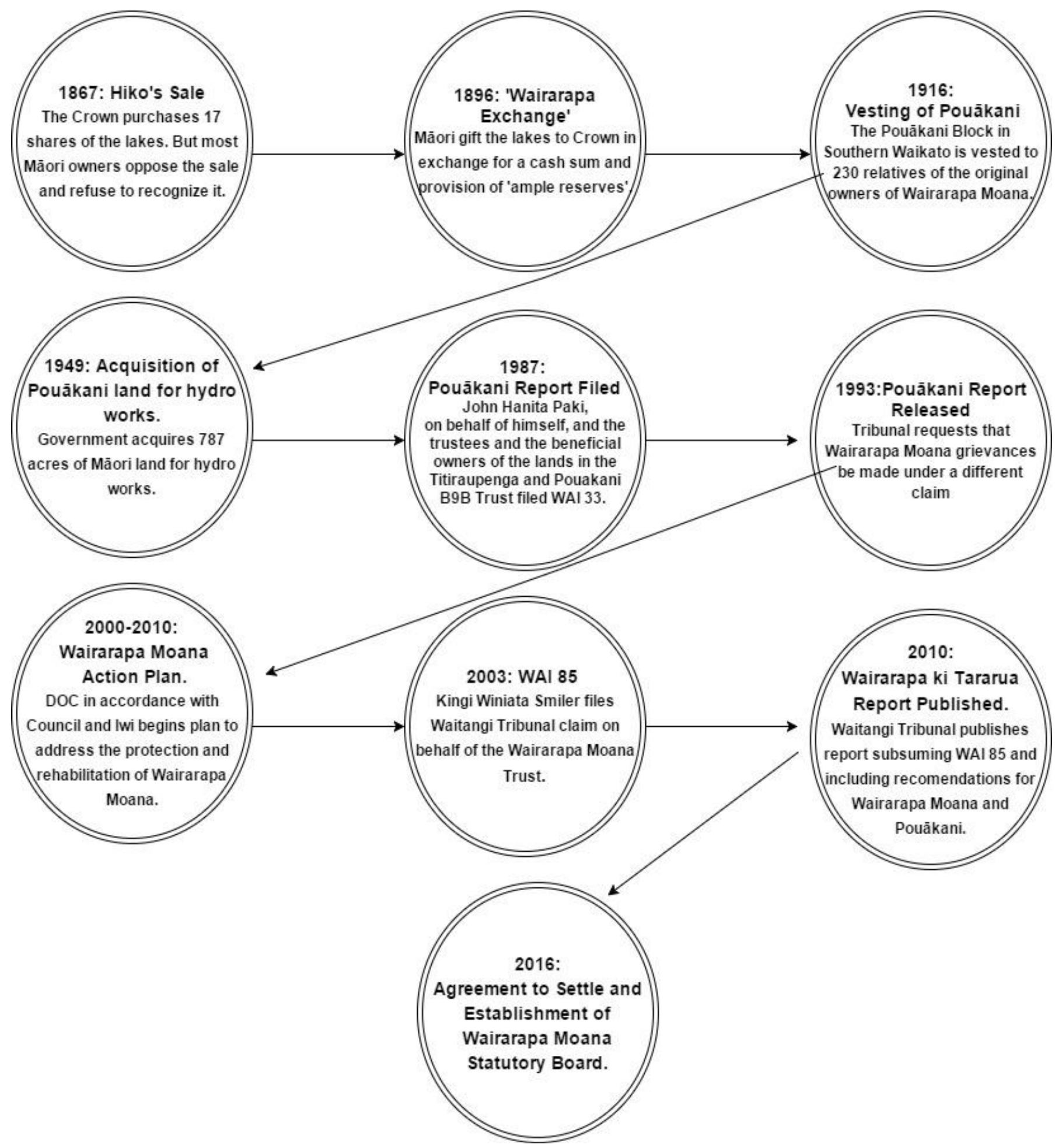




\section{Ruamāhanga Awa}

The Ruamāhanga Awa flows from the Tararua Ranges in the north-east of the Wairarapa, through the South Wairarapa Region, and down to Lake Ōnoke. Culturally the river is the lifeblood of the region, an important site for māhinga kai and home to taniwha to whom Wairarapa Māori can whakapapa. ${ }^{100}$ Throughout the twentieth century the Ruamāhanga River underwent significant ecological changes consequent of urban development, industrialisation and the rise of the agriculture industry. These changes have had significant cultural and ecological implications which are difficult to rectify due to the imbalance in political and cultural capital between notions of economic development and cultural values attributed to the wellbeing and interconnection of all living ecosystems known to Māori as ki uta ki tai.

The cultural significance of rivers for Tangata Whenua is beginning to be recognised in Waitangi Tribunal settlements, and by extension, at higher levels of national governance. This is evidenced by the development of the Wairarapa Moana Statutory Board and by the Te Awa Tupuna Settlement in which the Whanganui River was granted legal personhood. ${ }^{101}$ These settlements are indicative of a changing tide in fresh water relations in New Zealand, yet the swell is not even across the board. Many bodies of fresh water, the Ruamāhanga included, are subject to fierce contestation between economic, cultural and ecological interests. This is a situation which has gradually developed over the past century and has become intensified by the immense cultural and political capital granted to farming as New Zealand's predominant industry.

Beginning in the late-nineteenth century, European settlers began to instigate a number of topographical changes upon the Ruamāhanga River in order to manage the seasonal flooding of the Wairarapa Plains. Throughout the twentieth century the construction of stop banks and groynes significantly altered the flow of the river. By 1967 the Wairarapa region and its rivers had the second highest number of stop banks in the country, second only to the agriculturally intensive Canterbury region. ${ }^{102}$ The re-routing of the Ruamāhanga River was the most significant alteration to the natural topography of the region. It had severe implications for the health of the Wairarapa Moana, indigenous species and the spiritual and cultural values of Tangata Whenua. ${ }^{103}$ The dredging of the river channel to remove gravel to the lower bed also had a significant impact on the flow of the river

\footnotetext{
100 Royal, Cultural Values for Wairarapa Waterways. p.6.

${ }^{101}$ Te Awa Tupuna (Whanganui River Claims Settlement) Bill, Part 2, Section 14, New Zealand Government Legislation, 2014.

102 Knight, New Zealand Rivers. p.186.

103 The Wairarapa Ki Tararua Report; Volume III. p.851.
} 
and its water quality. ${ }^{104}$ Māori cultural values, as well as ecological values, were constantly undermined by flood protection works, which negatively impacted upon water volume and quality. ${ }^{105}$ These topographical changes are indicative of the imbalance of political capital between Pākehā and Māori, and evidence of a prioritisation of economic and urban development over cultural and ecological values.

Despite fierce lobbying from the meat, dairy and wool industries, legislation protecting watercourses from excess pollution appeared to be making headway by the 1960s. Yet transfers of responsibility for water quality over the latter part of the century muddied legislation. Under the LGA responsibility was transferred from the Ruamāhanga Catchment Board to the GWRC. Although water regulations became more stringent under statutory plans enabled by the RMA, the openness of the political system to corruption by corporate interests has not been mitigated.

Although industrial and sewage discharges have become subject to primary and secondary treatment, effluent from the three major South Wairarapa townships, and from Carterton and Masterton, is still being discharged into the Ruamāhanga. ${ }^{106}$ A 2010 lawsuit against Carterton industry 'Premier Bacon' was dropped after discussions with the firm. The company, who had been fined \$250,000 after unlawfully discharging two nutrients into the Mangatarere Stream, was pardoned on account of the contribution it made to the community said then secretary of Sustainable Wairarapa, Ray Stuart. ${ }^{107}$

Legislation in the latter part of the twentieth century became more stringent upon the issue of point source pollution but ignored the growing problem of agricultural pollution. Between 1971 and 2007 cattle numbers in the country increased by $61 \%$, significantly increasing levels of nitrogen and phosphorus loading consequent of agricultural run-off. ${ }^{108}$ A 2014 report on river water quality and ecological health in the Ruamahanga Whaitua found that vast sections of the region's watercourses, all of which flow into the Ruamāhanga river, did not meet national standards for water quality, testing positive for e-coli and dissolved reactive phosphorus, and having poor macroinvertebrate levels. ${ }^{109}$ The removal of river water for irrigation purposes contributed to low median flow statistics

\footnotetext{
104 Knight, New Zealand Rivers. p.186.

105 Royal, Cultural Values for Wairarapa Waterways. p.7.

106 The Wairarapa Ki Tararua Report; Volume III. p.851.

107 Don Farmer, 'Pressure eases on river polluter', Wairarapa Times Age, 18/05/2010, in Alan Wilde's Private collection of writings and newspaper clippings, Greytown.

108 Statistics New Zealand, 'Beef Cattle numbers as at June 30, from 1971'.

http://maxa.maf.govt.nz/statistics/pastoral/livestock-numbers/. (accessed 28/09/2016).

${ }^{109}$ Bunny, Milne and Laura Keenan, River water quality and ecological health in the Ruamahanga Whaitua. p.3.
} 
for the Ruamāhanga resulting in an overall warming of the watercourse and an increase in bacterial and algal growth. ${ }^{110}$ As Kaumātua identified in submissions to the Waitangi Tribunal these ecological changes have had a severe impact upon the cultural and spiritual values that Tangata Whenua attribute to the river. The use of the watercourse as a site for recreation and sourcing māhinga kai has been compromised, as have spiritual notions relating to the ecological health of the river concurrent to ki uta ki tai. ${ }^{111}$

The New Zealand dairy industry continues to grow exponentially despite debates generated by the 2013 'Dirty Dairying Campaign' and attempts at collaborative governance to mitigate water pollution. ${ }^{112}$ As discussed in previous areas of this thesis, water regulation of the Ruamāhanga River is ad-hoc and subject to market pressures and the immense cultural and political capital enjoyed by the farming community. While the Wairarapa ki Tararua report and GWRC reports have made recommendations for the acknowledgement of the cultural and spiritual values attributed to the Ruamāhanga River by Tangata Whenua, they do not exist in practice. A 2011 report on Cultural Values for Wairarapa Waterways found that 'Māori values attributed to rivers and streams throughout the Wairarapa Valley are consistently being compromised through low flows and poor water quality...There is an expectation from Iwi that the rivers and streams which once provided this nourishment for their community should be available to support their cultural identity.' ${ }^{113}$

\footnotetext{
110 Royal, Cultural Values for Wairarapa Waterways. p.23.

${ }^{111}$ See: The Wairarapa Ki Tararua Report; Volume III. Royal, Cultural Values for Wairarapa Waterways. \& Hansford, 'Water Liquidation'.

112 Knight, New Zealand Rivers. pp.230-239.

113 Royal, Cultural Values for Wairarapa Waterways. p.7.
} 


\section{A settlement for social equity?}

Fig.6. ${ }^{114}$

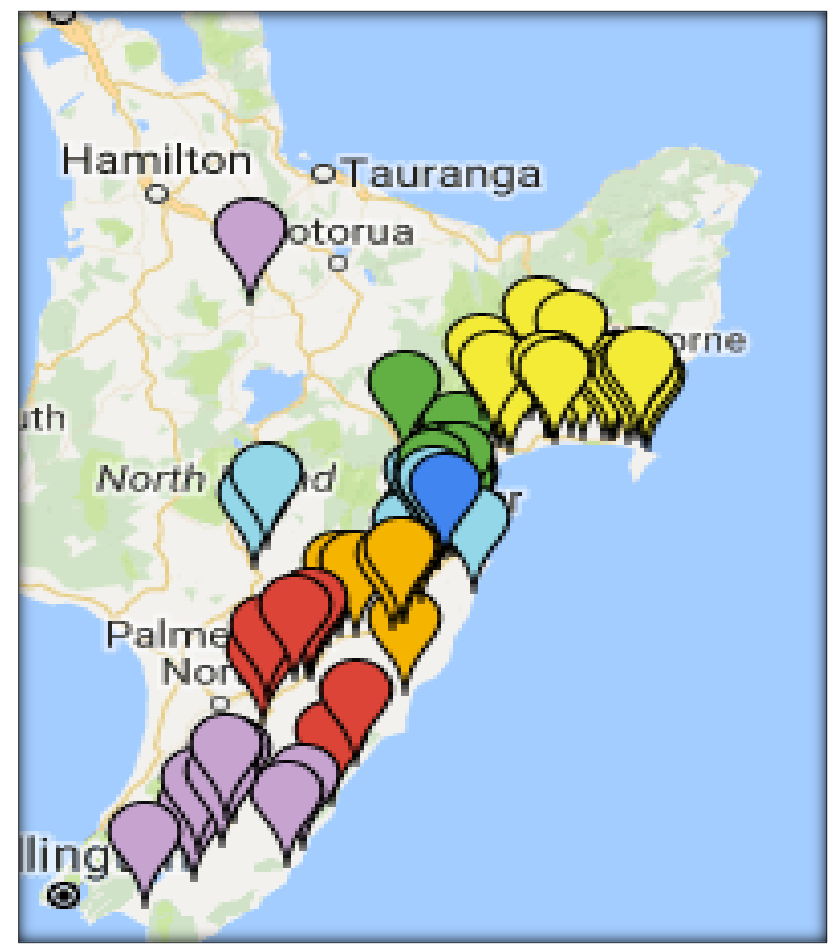

Fig.7. ${ }^{115}$

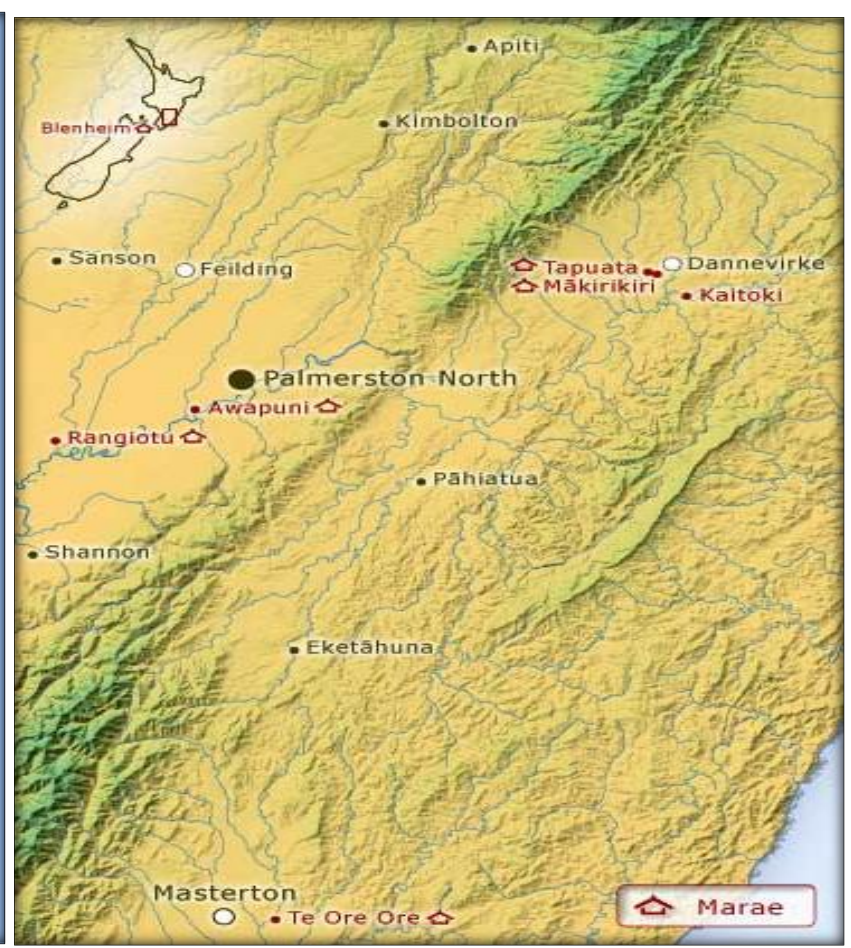

The purple pins in figure six represent marae affiliated with the Ngāti Kahungunu ki Wairarapa specifically, the red, orange, blue, pale blue, green and yellow pins represent other Ngāti Kahungunu marae with which the ki Wairarapa branch of Ngāti Kahungunu have varying degrees of engagement.

The above maps show the localities of Ngāti Kahungunu Marae and Rangitāne Marae. Both scholars and Māori continually identify Marae as the centres of colonial and neo-colonial resistance and of the continuation of māoritanga and Te reo Māori. ${ }^{116} \mathrm{~A}$ particular discrepancy between the Government drawn South Wairarapa Council lines and the rohe of Ngāti Kahungunu ki Wairarapa and Rangitāne o Wairarapa Māori is the bureaucratic separation of Māori from their Marae. Just three of ten Kahungunu ki Wairarapa Marae are located within the South Wairarapa district boundary: Kohunui at Pirinoa, Hau Ariki at Martinborough and Papawai at Greytown. ${ }^{117}$ For

\footnotetext{
${ }^{114}$ Ngāti Kahungunu Iwi Incorporated, Our Marae, http://www.kahungunu.iwi.nz/our-marae. (accessed 27/02/2017).

${ }^{115}$ Mason Durie and Meihana Durie, 'Rangitāne - 20th and 21st centuries: survival and adaptation', Te Ara - the Encyclopaedia of New Zealand, http://www.TeAra.govt.nz/en/map/1500/map-of-rangitane-marae. (accessed 27/02/2017).

${ }^{116}$ See, The Wairarapa Ki Tararua Report; Volume I.

The Wairarapa Ki Tararua Report; Volume II.

The Wairarapa Ki Tararua Report; Volume III.

\& Turoa Royal, 'The Marae in New Zealand, The Resource Centre of the Māori World', Te Tauihu o Ngā Wānanga; Indigenous voices, Indigenous places, Rachael Selby (ed.), Otaki, 2008. pp.6-12

${ }^{117}$ Ngāti Kahungunu Iwi Incorporated, 'Our Marae', http://www.kahungunu.iwi.nz/our-marae. (accessed 27/02/2017).
} 
Rangitāne o Wairarapa Māori their closest Marae is Te Ore Ore in Masterton, separated from the South Wairarapa by a district boundary, despite its geographical closeness.

Furthermore, one Ngāti Kahungunu ki Wairarapa Marae and six Rangitāne Marae lie outside of the confines of the GWRC all together. Marae are physical sites of ancestral significance, the tahuhu and maihi traditionally depict the whakapapa of the marae. The spiritual significance of the marae is a fundamental part of its function as a meeting house and centre of ritual and celebration. ${ }^{118}$ Separation, voluntary or otherwise from their rohe, marae and whenua continually exacerbates historically thwart access for Māori to local government processes, directly affects their mana, and further restricts their ability to act as kaitiaki over their rohe. ${ }^{119}$ The restrictions enforced by the LGA made access to decision-making processes in other districts or regional councils significantly more difficult.

Fig.8. ${ }^{120}$

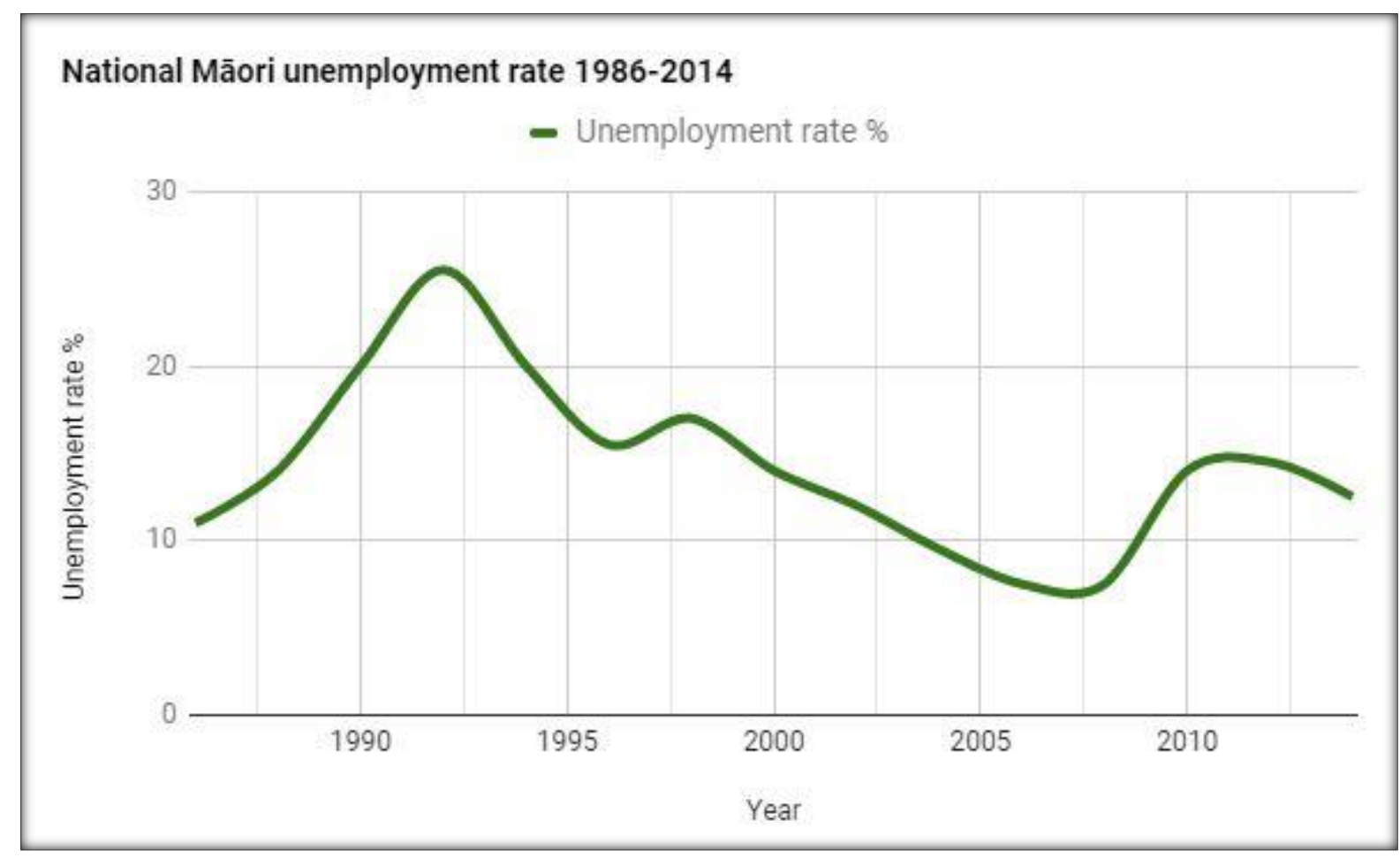

As in other tribal rohe, South Wairarapa Māori have migrated elsewhere in considerable numbers. Numerous scholars have discussed the weakening of whanaungatanga and Te tino rangatiratanga consequent of urban migration. ${ }^{121}$ Māori themselves have also been vocal about their reasons for

\footnotetext{
${ }^{118}$ Merata Kawharu, 'Environment as marae locale', in Māori and the Environment: Kaitiaki. p.221.

${ }^{119}$ Veronica. M, H. Tawhai, 'Rāwaho: In and out of the environmental engagement loop,' in Māori and the Environment: Kaitiaki. p.81.

120 Ministry of Social Development, The Social Report 2016, Wellington, June 2016. p.106.

${ }^{121}$ See, Le Heron and Pawson, Changing Places.
} 
abandoning their turangawaewae. Māori land veteran Punga Paewai stated in 1993 'Māori land is like an asset that has become a liability.....Early partitions have left many owners with land that is not viable for development as some are too small to be economic, others have access problems, or are irregular and ribbon shaped. ${ }^{122}$ For Māori who remained land owners into the twentieth century, urban migration posited a more secure future for themselves and their whanau than attempting to compete with Pākehā farmers on land that was significantly less suitable. ${ }^{123}$ Paora Ammunson touched upon the disconnect between Ngāti Kahungunu Māori, their turangawaewae and their role as kaitiaki: 'As an iwi, we have beautiful values about where we come from, but eighty percent of us are physically disconnected from those places.... If we are going to tell people we have strong views about how the world should be, then we actually need to be here.' ${ }^{124}$

Although the Māori population of the South Wairarapa increased by over fifteen percent between 2006 and 2013, fort percent of Māori were under the age of fifteen years old. ${ }^{125}$ The median age of Māori in the South Wairarapa in 2013 was twenty-three, nearly half that of the district's overall median age of forty-five. ${ }^{126}$ This indicates that urban migration for South Wairarapa Māori of employment age is still prevalent. Despite this the 2013 Census showed that the unemployment rate of South Wairarapa Māori was three percent lower than the national Māori average. ${ }^{127}$ For the employment aged Māori the most common occupation was identified as 'labouring'. ${ }^{128}$ While labouring is a broad term it is reasonable to assume that alongside those working on the building and maintenance of infrastructure, a significant number of Māori were being employed as farm and vineyard labourers. The expansion in size of farms and vineyards in the region created the necessity to move outside of family owned and operated models of business. However, the percentage of employment aged Māori earning less than $\$ 20,000$ dollars a year was more than ten percent higher than that of their non-Māori counterparts. ${ }^{129}$ That nearly half of the population identifying as Māori

\footnotetext{
Pare Keiha \& Paul Moon, 'The Emergence and Evolution of Urban Maori Authorities: A Response to Maori Urbanisation', Te Kaharoa, Vol.1, 2008. pp.1-17.

Tawhai, 'Rāwaho: In and out of the environmental engagement loop'. pp.77-94.

\& The Wairarapa Ki Tararua Report; Volume I.

122 The Wairarapa Ki Tararua Report; Volume II. p.622.

123 The Wairarapa Ki Tararua Report; Volume II. p.621.

${ }^{124}$ Mahinarangi Forbes, 'Paora Ammunson', Waitangi Monday Programme, RNZ National, 06/02/2017.

125 Statistics New Zealand, 'Quick Stats about the South Wairarapa District', Census 2013, http://www.stats.govt.nz/Census/2013-census/profile-and-summary-reports/quickstats-about-aplace.aspx? request value=14536\&tabname+\&sc device=pdf. (accessed 24/06/2016).

126 ibid.

127 Ministry of Social Development, The Social Report 2016. p.106.

\& Statistics New Zealand, 'Quick Stats about the South Wairarapa District'.

128 Statistics New Zealand, 'Quick Stats about the South Wairarapa District'.

129 ibid.
} 
were in low salary employment suggests that labouring was not a well-payed job. While the GDP of the South Wairarapa increased by over four percent per annum in the five years leading to 2013, statistics suggest that this was reflected by higher employment rather that increased wages. ${ }^{130}$ These observations suggest that while Māori have benefitted from new employment opportunities that have opened up in the past thirty years, they are still at a social and economic disadvantage in the region compared to their non-Māori counterparts.

\section{A cultural and ecological revival?}

The relationship between the neoliberal reforms of the 1980s and the political and cultural position of Rangitane o Wairarapa Māori and Ngati Kahungunu Māori has not been clear cut. In some areas reforms have exacerbated historical grievances between Māori and Government, where-as in others Māori appear to have been the unlikely benefactors of the changing political currents of neoliberal change.

To some extent the political ideology of neoliberalism with its emphasis on individual right has given Tangata Whenua an opportunity to undergo a process of cultural revival in an atmosphere of reconciliation and cultural awareness. On other levels, the political and cultural capital of Tangata Whenua has been weakened further through legislation such as the LGA and the RMA which both exclude Māori from bureaucratic proceedings. While the RMA acknowledges the Māori worldview it continues to undermine it in policy implementation.

While there have been sites of ecological, economic and cultural redress many of the historical grievances presented to the Waitangi Tribunal, the Wairarapa Moana Exchange included, have moved beyond simple redress. It is socially, culturally, economically and physically impossible to return the Wairarapa region to the state in which nineteenth century settlers found it. Not only has the land been physically altered, but it is now subject to the dominant capitalist value system rather than that of Mātauranga Māori and māoritanga. This has been visible through the persistence of the degradation of the Ruamāhanga River through agricultural and industrial development, the continuance of the seizing of Māori land for public works, and the prioritisation of corporate fishing and oil interests over the customary rights of Māori.

There is an ongoing incongruence between the Māori worldview and the worldview of successive New Zealand Governments. This has its origins in the mistranslation of the Treaty of Waitangi and

${ }^{130} \mathrm{Dr}$ Ganesh Nana, Fiona Stokes and Hugh Dixon, Local Authorities Rankings 2013, Berl Economics, January 2014. p.19. 
the mismatch between tikanga and individualistic capitalism, and continues in many facets of society today, from contesting notions of ownership to misunderstandings about kaitiakitanga. Despite significant attempts by governments to acknowledge māoritanga, there is evidence of a distinct lack of understanding about how to reconcile the two world views. Scholars such as Maria Bargh have argued that a return to indigenous worldviews, such as that of Tangata Whenua, would have positive ecological implications. ${ }^{131}$ However, such a shift is unlikely ever to occur due to the extreme re-shuffling of corporate and economics interests that it would entail, particularly with regards to the agriculture industry.

While Ngāti Kahungunu and Rangitane o Wairarapa Māori have established greater political and cultural capital in some confined areas, they still hold significantly less economic capital than their non-Māori counterparts. Māori values and interests are still marginalised by those of council, agricultural and industrial interests. One may see the neoliberal changes of the 1980 s as a time period in which South Wairarapa Māori took advantage of political change in order to seek historical redress. However, that which they have been granted is indicative of a capitalist system in which social and political change facilitates changes in resource use and environmental change. ${ }^{132}$ There is little evidence of a cultural shift toward a mainstream acknowledgement of māoritanga in the region, and those areas in which redress has been successful regard land and resources deemed no longer necessary for agricultural and industrial use.

\footnotetext{
${ }^{131}$ Maria Bargh, 'A Blue Economy for Aotearoa New Zealand?'. p. 459

132 Harvey, Justice, Nature and the Geography of Difference. p.190.
} 


\section{Conclusion}

The reforms of 1984 had a profound short term effect on the South Wairarapa. As a local economy dominated by pastoral farming, withdrawal of government support and exposure to market pressures was particularly stressful. This economic strain is well documented in historiographical literature; however, this thesis sought to reconsider the narrative framework with which historians have examined neoliberal change and its repercussions. By examining the historical context of the twentieth century in depth, it is apparent that many of the changes frequently attributed to neoliberal reform are both continuities of pre-existing cultural, political and economic frameworks, and consequences of them. It is seen that financial struggle, productivist agriculture and changes in land use all pre-dated the reforms of the 1980s. They are altered by political context but are nonetheless symptomatic of the much longer contexts of colonialism and capitalism.

There have been a significant number of cultural and physical changes to farming in the South Wairarapa over the past thirty years. These primarily concern production relations, the resources used in production and the subjective values attached to relations of production and natural resources. These relations exist across economic, political, cultural, social and environmental factors and are constantly shaping, and being shaped by, one another. When placed within a longer historical trajectory, environmental change in the South Wairarapa is linked to relations of farming capital within the region, the predominance of an agricultural productivist culture and the New Zealand economy's relationship with international markets. All of these relationships pre-date neoliberal restructuring, and in many ways restructuring may even be seen as a consequence of these relations.

There is a significant degree of synonymy between agricultural productivist culture and the intensification of farming. What has changed in recent years is the resource being intensified. There is little evidence of a causal link between neoliberal reform and intensification. ${ }^{1}$ The culture of agricultural productivism remained unchanged, but economic imperatives and necessities changed the nature of what was being produced. This had a profound environmental, political and social effect because cattle and sheep require different farm management strategies and interact with natural resources in different ways. Traditional notions of 'good farming' are in conflict with more ecologically minded notions of sustainability and the value of natural resources.

\footnotetext{
${ }^{1}$ Haggerty, Campbell and Morris, 'Keeping the stress of the sheep? Agricultural intensification, neoliberalism and 'good' farming in New Zealand'. p.776.
} 
Farmers in the South Wairarapa have long possessed a significant amount of cultural capital. Despite yo-yoing levels of political and economic capital, farmers remained culturally dominant in the South Wairarapa. As commentators such as Alan Wilde have identified, this enables voices of the farming community to be louder than those of other residents. Cultural capital was maintained, strengthened and relied upon after the reforms of the 1980s. However, in recent years the growing awareness of the impacts of intensive farming on natural resources has begun to threaten the cultural capital of farmers by challenging perceptions of what it is to be a 'good farmer'. Current voices within the South Wairarapa community and the nation as a whole are now contesting the environmental viability, particularly of dairy farming, and the nature of what sustainability means.

While agriculture in the South Wairarapa has a long historical trajectory, the modern Martinborough wine industry originated slightly before - and developed in the context of - the reforms of 1984 . The suggestion by some scholars that the industry was founded upon a post-reform push for diversification is inaccurate. Viticulture in the region has its origins in two areas: the first being the political and economic climate of the 1960s and 1970s; and the second being the topographical and climatic similarities between the Martinborough region and other successful winegrowing regions.

From its conception, the Martinborough wine industry rejected the productivist culture that dominated the agriculture industry and wine production elsewhere in the country. Drawing upon the Martinborough's similarities to the Burgundy region, the pioneer winemakers developed an appellation as a mark of distinction and an indicator of high-quality, exclusive, produce. The exclusivity and boutique nature of the industry has been the largest determinant of the shape of the industry and the changes that Martinborough has undergone over the past thirty years.

The Martinborough wine industry showcases the effectiveness of successful marketing in shaping consumers' perceptions of a product. The original Martinborough Terraces Appellation, established off the back of a comparison of its soils to those of Burgundy, was important for establishing the 'terroir' of Martinborough wine. Yet, as the industry developed outside of the confines of the original appellation, neither the Burgundy comparison nor the exclusivity of the region's wines was lost. The branding of the town itself as a 'wine village' is shown in the work of scholars such as Peter Howland and Joanna Fountain, to entrench consumers' perceptions of quality, while simultaneously offering a rural idyll in which consumers can enjoy boutique accommodation, eateries and shops alongside their vineyard experiences.

The changing physical and ideological picture of Martinborough also resulted in a demographic change: tourist numbers have steadily increased, as permanent residents have decreased in 
number. Many dwellings are now holiday homes, bed and breakfasts or hotels. This altered the structure of community, many residents no longer know their neighbours, and some object to the constant interruption of their daily lives consequent of tourism.

The small-scale production of the Martinborough wine industry resulted in a production and consumption dynamic that is far less corporate in nature than that of agricultural products and winemaking regions elsewhere in the country. The marketing of the industry as 'boutique' was guided by knowledge of national and international markets, of consumer demand and subjectivities. Unlike the agriculture industry, and winemakers elsewhere, Martinborough winemakers took advantage of the market knowledge facilitated by the reforms of 1984. Its success suggests that the New Zealand culture of productivism is ignorant of one of the rare benefits of neoliberalism. On the other hand, the challenges that productivism poses to small scale producers accentuates the selfserving nature of a neoliberal economic climate, where competition rather than demand drives production.

The rejection of productivism has been an important aspect of the domestic success of Martinborough wines and of the development of the town's tourist trade. However, exposure of the industry both to foreign interest and international markets resulted in difficulties. Corporate interest and absentee ownership threatens the community dynamic enjoyed by Martinborough winemakers and increases competitiveness. More significantly, as small scale producers, Martinborough winemakers are small fish in a big pond when it comes to exporting. The exclusivity of Martinborough wines is not as effective internationally where New Zealand wines in general have a good reputation.

The position of Ngāti Kahungunu ki Wairarapa and Rangitāne o Wairarapa within the South Wairarapa is essential to an understanding of the region's environmental history and of alternative cultural frameworks and resource management. Productivism is fundamentally at odds with the traditional world view of Tangata Whenua. Where productivism entails producing as much as possible from the available resources, ki uta ki tai entails the interconnectedness of people and their natural resources, and the importance of inter-generational equity. This is particularly evident in the South Wairarapa where the environmental impact of productivism is seen most evidently in waterways. It is significant that Ngāti Kahungunu ki Wairarapa and Rangitāne o Wairarapa Māori have sought not only economic and social redress, but also cultural redress intrinsically linked to the ecological health of the region's natural resources. Claimants in the Wairarapa ki Tararua claim 
emphasised the importance of the region's waterbodies, the tuaone and tahuaroa, Wairarapa Moana and Ruamāhanga Awa.

The process of colonisation ignored the worldview and culture of Ngāti Kahungunu ki Wairarapa and Rangitāne o Wairarapa Māori. From the late nineteenth century to the mid-twentieth century, legislation passed by the Crown enabled the South Wairarapa landscape to be consciously altered in favour of pastoral farming, displacing the cultural and spiritual values that Tangata Whenua had for the Wairarapa Moana Wetlands, Ruamāhanga Awa and Mātakitaki a Kupe (Cape Palliser) coastline. From the early twentieth century capitalism has placed further strain on the resources of the region and the relationship between Tangata Whenua and their land, in a less conscious but similarly destructive way. The commercial fishing of the Wairarapa Moana and Mātakitaki a Kupe, and the productivist farming of the Wairarapa plains and hill country, has had a significant ecological impact.

It may be argued that the post-colonial and individualistic political atmosphere of the past thirty years has provided an advantageous climate for redress to South Wairarapa Māori. While the Waitangi Tribunal claims process has facilitated this, it has had limited success. The Wairarapa Moana project demonstrates a positive step toward ecological and cultural redress. Yet, productivism continues to compromise water quality. The inequity between Māori cultural values and commercial capitalism has been evident through contemporary debates such as that over the foreshore and seabed. Furthermore, statistics show that South Wairarapa Māori continue to be at a social and economic disadvantage when compared to their non-Māori counterparts.

Until there is a reconciliation between productivism and ki uta ki tai the realisation of kaitiakitanga for South Wairarapa Māori will be implausible. While New Zealand governments continue to emphasise the necessity of productivist agriculture for economic development, the degradation of natural resources and suppression of traditional Māori values will continue. Legislation continues to show a misunderstanding of key elements of Māori culture through mistranslation and assumptions based on Western cultural norms. Although steps such as the legal protection of the Whanganui River and the Wairarapa Moana project suggest pockets of reconciliation, they are isolated and exist in exception to the degradation of natural resources elsewhere in the country.

It has been the intent of this thesis to re-examine the economic, social and environmental changes of the past thirty years and their relation to the neoliberal reforms of the 1980s. An understanding of neoliberal reform as a reaction to the protracted struggle between New Zealand's protected domestic economy and the international free market economy is crucial to an investigation of how 
the reforms impacted upon society. It has not been the intent of this thesis to argue that neoliberal reform was the only reaction, nor the best reaction to the economic crisis faced by New Zealand by the end of the 1970s. Rather, this essay has sought to extend the narrative framework within which historians have viewed the changes of the past thirty years, by examining their place in the longer economic, social and environmental history of the South Wairarapa.

While the neoliberal reforms of the 1980s inarguably had a profound economic effect on farmers and rural communities as a whole, this thesis has demonstrated that in the case of the South Wairarapa, these effects were usually short term. The ways in which the community changed and developed over the thirty years demonstrates that changes are as much a continuity of pre-existing cultures and behaviours as they are a consequence of, or response to reforms.

Diversification into dairy farming may be seen as a response to an awareness of the market realities of pastoral farming. Yet, these realities pre-dated reform and statistics show that despite government subsidization the income of South Wairarapa sheep farmers was unpredictable at best. Furthermore, the intensification of farming, often attributed to neoliberal reform, is a continuation of productivist culture that had been particularly prevalent in sheep farming since the 1920 s. Overall stock numbers have fallen, what has changed is what is being farmed, not how it is being farmed.

Conversely, the development of the Martinborough Wine Industry, which pre-dates neoliberal reform, cannot rationally be attributed to a post-reform push for diversification. In contrast to the agricultural industries of the region, the Martinborough wine industry rejects productivism in favour of small scale production. Although the production and marketing of Martinborough and its wines displays a thorough understanding of the consumer market, its development has been distinctly uncorporate in nature. Though these industries have changed and developed within a neoliberal capitalist system, to state that neoliberal reform was the driver of these changes is misinformed. Observation of the South Wairarapa suggests that the fundamental drivers of change lie outside of the immediacy of these reforms: both change, and the reforms themselves were a result of broader ecological revolutions pertaining to land use, cultural change and resource distribution.

As has been seen, the environmental transformation of the South Wairarapa long predates the economic reforms of the 1980s. We also see that this transformation was driven by two other dominant political and social forces: colonisation and capitalism. To view the environmental changes of the past thirty years in isolation of this ignores the impact that culture has on environment. As William Cronon states 'calling a place a home inevitably means that we will use the nature that we 
find in it. ${ }^{2}$ The fundamental difference between the Māori culture of resource use and the European culture of resource use, and the domination of the latter over the former, is evidence of both an alienation of Tangata Whenua from their home and a change in the way that the natural resources of the South Wairarapa were utilised. Due to the centrality of the ecological health of the natural environment to Tangata Whenua, many of the claims made to the Wairarapa ki Tararua enquiry placed grievances over historic misappropriation of natural resources in accordance with contemporary grievances over the poor ecological state of the region's waterbodies. Yet, continued cultural dominance of capitalist values over those of Tangata Whenua significantly limits the ability of the Waitangi Tribunal settlements to offer meaningful redress.

An acknowledgement of longer trends in New Zealand society enables a more informed assessment of the ways in which the ecological health of the region's waterbodies may be restored. As has been discussed, agricultural intensification is not a recent phenomenon: it is a continuation of the longrunning trend of agricultural productivism. In considerations of how to rationally reconcile the economy with environmental sustainability it makes no sense to return to farming a less environmentally damaging but economically unviable product. A return to sheep farming as the dominant practice is not an option; nor is it as simple as rejecting productivism all together, as the Martinborough wine industry did. The market for dairy produce is both far more competitive and far less subjectively driven than that of wine. New Zealand's emphasis on productivism is not unique in this industry, and therefore rising prices are likely to mean falling sales. The situation is complicated further by the fact that New Zealand's second largest industry, tourism, does not neatly co-exist with the agriculture industry as environmental degradation harms the country's 'clean green' image. Furthermore, it has been found that South Wairarapa tourists are drawn not only by wine tourism but by idealised notions of rural life, in which the realities of agricultural production clash with their imagined rurality. ${ }^{3}$

The current economic and political environment of New Zealand makes a change from productivist culture difficult. As in the South Wairarapa, many of the country's modern economies have been founded on agricultural productivism. Replacing the capitalist culture with traditional Māori culture, as has been suggested by cross cultural approaches such as 'blue ecology', is an understandable ideological consideration. However, it ignores the realities not only of Tangata Whenua's continued lack of cultural capital, but also of the New Zealand economy. Propositions that the use of resources

\footnotetext{
${ }^{2}$ Cronon (ed.), Uncommon Ground. p.88.

${ }^{3}$ Howland, 'Martinborough's Wine Tourists and the Metro-Rural Idyll'. p. 80.
} 
should be determined by necessity and sustainability are similarly ideologically prevalent and well founded. However, the reality of achieving these considerations in a climate of competing social, cultural, environmental and economic subjectivities is not presently achievable. As Harvey states in his theory of ecological revolutions, social change leads to changes in resource use, which in turn results in different environmental implications. ${ }^{4}$ While Tangata Whenua, environmentalists and other actors currently pose a significant threat to the cultural capital of farmers, it remains uncertain how the current cultural and therefore environmental system of the South Wairarapa, and of Aotearoa, will develop.

\footnotetext{
${ }^{4}$ Harvey, Justice, Nature and the Geography of Difference. p.129.
} 


\section{Bibliography}

\section{Newspapers/Magazines}

Australian Geographer

Decanter Magazine

The Dominion Post

Fishhead Magazine

The New York Times

New Zealand Geographer

New Zealand Geographic

Scoop Independent News

The Sunday Star Times

The Wairarapa Times Age

Wine Spectator

\section{Conference Presentations and Papers}

Hunt, Leslie. M, Fairweather, John. R, Rosin, Chris. J, Campbell, Hugh, Lucock, Dave \& Greer, Gen, 'Doing the Unthinkable: Linking famers' breadth of view and adaptive propensity to achievement of social, environmental and economic outcomes', Conference Paper 18th International Farm Management Congress- Methven, Canterbury Conference proceedings, New Zealand, 2011.

McCallum, Neil, 'Wine', The Butcher's Talk Series, Victoria University of Wellington, Lecture Theatre 4, Faculty of Law, Government Buildings, Wellington, 08/05/2016.

McAloon, Jim, 'Merino, Mussels and Merlot: New Zealand's thriving resource-based economy?', Conference paper, Asia-Pacific Economic and Business History Conference, Adelaide, February, 2016.

Thompson, David, Forbes, Sharon. L, “Going "green" to find "gold" in wine: A case study of a New Zealand wine producer', 6th AWBR International Conference, Bordeaux Management School, 9-10 June 2011. 


\section{Collections}

Alan Wilde's private collection of writings and newspaper clippings, Greytown.

\section{Oral History Interviews}

Cormack, Heather, Martinborough Winemakers Oral History Project, Wairarapa District Archive, Masterton, 1990-91, record no. 505131.

\section{Author Interviews}

Rainford, Eleanor. J, Email correspondence with Dr Russell Death, Monday 03/10/2016.

Rainford, Eleanor, Interview with Paora Ammunson, Greytown Library, 31/11/2016, File 0135, Tascam DR60D.

\section{Radio Interviews}

Campbell, John, 'Dr Russell Death; Fresh water results worst ecology professor has seen', Checkpoint, RNZ National, 22/08/2016.

Forbes, Mahinarangi, 'Paora Ammunson', Waitangi Monday Programme, RNZ National, 06/02/2017.

\section{Documentary Footage}

Hunter, Daniel. O, Muir, James (directors), Riverdog, Documentary 2010, 25.09mins. 


\section{Legislation}

Foreshore and Seabed Act, Public Act, No.93, 24th November 2004.

Resource Management Act 991; Reprint as at December 2016, Public Act, 1991.

Te Awa Tupuna (Whanganui River Claims Settlement Bill), 2014.

Territorial Sea, Contiguous Zone, and Exclusive Economic Zone Act, Reprint as at 15th December 2005, Public Act, No. 28, 26/09/1977.

\section{District, Regional and National Government Papers}

Beca Carter Hollings and Ferner Ltd.(Beca), Report; South Wairarapa District Council Resource Consent Application and Assessment of Effects on Environmental Coastal Protection Works, Greater Wellington Regional Council \& Beca, 24/04/2009.

\section{http://www.grwc.govt.nz/assets/Resource-Consents/6379 sWDCRCApplicati s124449.pdf.} (accessed 07/03/2017).

Bragato, Romeo, Report for the Prospects of Viticulture in New Zealand; Together with Instructions for Planting and Pruning, New Zealand Department of Agriculture, Wellington, 1895.

Bunny, Tessa, Milne, Juliet \& Keenan, Laura, River water quality and ecological health in the Ruamahanga Whaitua, Ruamahanga Whaitua Committee; Wairarapa, Masterton, July 2014.

Cowie, J.D \& Milne, J.D.G, General Suitability of the Wairarapa Plains for Cropping, Report WN1, Soil Bureau District Office, Department of Scientific and Industrial Research New Zealand, 1980. Department of Agriculture and Fisheries, Annual Report, Wellington, 1959.

Field, R.R.O, Clark, D.A, Brougham, R.W, Wairarapa Hill Country Survey, Unpublished D.S.I.R Report, 1982.

Gibbs, H.S \& Vucetich, C.G, Soils of Martinborough, Soil Bureau, Department of Scientific and Industrial Research. www.grassland.or.nz/publications/nzgrassland publication 1782.pd. (accessed 11/07/2016).

Greater Wellington Regional Council, $A$ guide to managing stock access to waterways in the Wellington Region, Wellington, August 2011. 
Ministry for Culture and Heritage, 'Masterton under no-license', updated 30-Jun-2014.

https://nzhistory.govt.nz/politics/temperance-movement/masterton-under-no-license. (accessed 09/05/2017).

Ministry for the Environment, 'Climate Change Projections for the Wellington and Wairarapa Region', 30/06/2016.

http://www/mfe.govt.nz/climate-change/how-climate-change-affects-nz/how-might-climatechange-affect-my-region/wellington. (accessed 05/10/2016).

Ministry for the Environment, 'The Dairying and Clean Streams Accord: Snapshot of Progress 2004/2005', May 2005.

http://maxa.maf.govt.nz/mafnet/rural-nz/sustainable-resource-use/resource-management/saityclean-stream/dairy-clean-stream.pdf. (accessed 06/10/2016).

Ministry of Agriculture and Forestry, Farm Monitoring Report, Wellington, December, 1986.

Ministry of Agriculture and Forestry, The Economic Value of Irrigation in New Zealand, Technical paper No: 04/01, ISBN No: 0-478-07798-X, April 2004.

http://ecan.govt.nz/publications/Reports/cwms-tech-rpt-3b-Economic-value-of-Irrigation-Apr-04final.pdf. (accessed 26/07/2016).

Ministry for Culture and Heritage, 'Masterton under no-license', updated 30-Jun-2014.

https://nzhistory.govt.nz/politics/temperance-movement/masterton-under-no-license. (accessed 09/05/2017).

Ministry of Social Development, The Social Report 2016, Wellington, June 2016.

Miskell, Boffa, Wairarapa Landscape Study 2010; Landscape Character Description, Greater Wellington Regional Council, August 2010. http://www.gw.govt.nz/assets/councilpublications/Wairarapa\%20Character\%20Study\%20August\%202010.pdf. (accessed 28/09/2016).

New Zealand Government, Background note; Gaps between ethnic groups, some key statistics, New Zealand Parliamentary Library, Wellington, 01/06/2000.

http://www.parliament.nz/resource/ennz/OOPLSocRP00101/dd813ed30474d07ed48b8da60257af8bac15a7df. (accessed 20/04/2017). Ngāti Kahungunu ki Wairarapa Tāmaki nui ā Rua and The Crown, Agreement in Principle to Settle Historical Claims, 7th May 2016. 
Potangaroa, Joseph, Tuna Kuwharuwharu; The Longfin Eel: An educational resource, Facts, threats and how to help, Rangitāne o Wairarapa Inc., Greater Wellington Regional Council, Department of Conservation, 2010.

The Pouakani Report, Waitangi Tribunal Report, 1993, WAI 33.

Report on the Crown's Foreshore and Seabed Policy, Waitangi Tribunal Report, 2004, WAI 1071.

Royal, Caleb, Cultural Values for Wairarapa Waterways, Ohau Plants LTD \& Greater Wellington Regional Council, November 2001.

http://www.gw.govt.nz/assets/Our-Environment/Environmental-monitoring/Cultural-values-forWairarapa-Waterways-report.pdf. (accessed 13/12/2016).

South Wairarapa District Council, 'Wairarapa Maps', District Plan.

http://mapping.gw.govt.nz/Wairarapa/. (accessed 04/05/2017).

The Treasury, New Zealand Economic and Financial Overview 2012, Industrial Structure and Principle Economic Sectors.

http://www.treasury.govt.nz/economy/overview/2012/nzefo-12.pdf. (accessed 06/10/2016).

The Wairarapa ki Tararua Report; Vol.I The People and the Land, Waitangi Tribunal Report, 2010, WAI 863.

The Wairarapa ki Tararua Report; Vol.II The struggle for control, Waitangi Tribunal Report, 2010, WA1863.

The Wairarapa ki Tararua Report; Vol.III Powerlessness and Displacement, Waitangi Tribunal Report, 2010, WAI863. 


\section{Non-Governmental Reports}

ANZ \& New Zealand Winegrowers, New Zealand Wine Industry: Full Bodied Growth, June 2016. file://C:/Users/User/Downloads/NZ-Wine-Industry-Full-Bodied-Growth.pdf. (accessed 01/05/2017).

Baker, D.O, Todd, D.B, Consultants Annual Report, Wairarapa Farm Improvement Club, Masterton, 1983.

Conforte, Daniel, Garnevska, Elena, Kilgour, Mark, Locke, Stuart \& Scrimgeour, Frank, The Key Elements of success and failure in the NZ Dairy Industry, Research Report No.313, Lincoln University, Christchurch, December 2008.

Dairy NZ, 'Sustainable Dairying: Water Accord', http://www.dairynz.co.nz/environment/in-yourregion/sustainable-dairying-water-accord/. (accessed 28/09/2016).

De Vos, Antoon, Deer Farming; guidelines on practical aspects, Food and Agriculture Organization of the United Nations, Rome, 1982, Te Ara-the Encyclopaedia of New Zealand.

http://TeAra.govt.nz/en/map/1500/map-of-rangitane-marae. (accessed 27/02/2017).

Horizon Research, Farming and the Environment: Conducted for Fish and Game New Zealand, Palmerston North, January 2014.

Nara, Ganesh, Stokes, Fiona \& Dixon, Hugh, Local Authorities Rankings 2013, Berl Economics, January 2014.

Slater, Rod (ed), Beef and Lamb New Zealand Reference Guide, 3rd edition, 2010.

http://www.beeflambnz.co.nz/resources/Reference Guide.pdf. (accessed 20/06/2016).

Society for Promotion of Community Standards, 'Abuse of Alcohol at Toast Martinborough Wine Festival', 22/12/2011. http://www.spcs.org.nz/abuse-of-alcohol-at-toast-martinborough-winefestival/. (accessed 20/04/2017).

Sustainable Winegrowing NZ, Audit Procedures for Vineyards and Wineries.

http://www.nzwine.com/assets/sm/upload/j1/dh/fa/9b/SWNZ\%20AUDIT\%20PROCEDURES\%20.p df. (accessed 10/05/2016).

Sustainable Winegrowing NZ, Sustainable Winegrowing New Zealand Standards, http://www.nzwine.com/sustainability. (accessed 10/05/2016). 
Wairarapa Moana Incorporation, Wairarapa Moana Trust; Distributing to shareholders, beneficiaries and their descendants the benefits accrued.

http://wairarapamoana.org.nz/page133387.html. (accessed 01/03/2017).

Wairarapa Moana Incorporation, Wairarapa Moana Incorporation Waitangi Tribunal Claim; WAI 85. http://wairarapamoana.org.nz/page75857.html. (accessed 28/11/2016).

\section{University Theses and Reports}

Douglas, Chad, Latitudinal Limit of Commercial Viticulture in New Zealand, MSC thesis, University of Otago, 2000.

Howland, Peter, Metro-rurality, social distinction \& ideal reflexive individuality: Martinborough's Wine Tourists, Anthropology PHD thesis, University of Canterbury, 2008.

Parker. W. J, A Study of Management Practices and Productive performance on a Sample of Hill Country Sheep Farms in North-East Wairarapa, Unpublished Masterate Thesis, Massey University, Palmerston North, 1984.

Shipley, Susan. M, Women's employment and Unemployment: a research report, Massey University Department of Sociology and The Society for Research on Women in New Zealand inc., Palmerston North, 1982.

Spall, James. G, Diversification of Wairarapa Hill Country; Potential for agroforestry, Thesis presented in partial fulfilment of the requirements for the Degree of Master in Agricultural Science, Massey University, Palmerston North, 1987. 


\section{Journal Articles}

Allen, Harry, 'Community and the reform of local government in New Zealand', Social Analysis: The International Journal of Social and Cultural Practice, Vol.43, No.2, Backwaters run deep: Locating New Zealand Social Anthropology, July 1999. pp. 70-87.

Bargh, Maria, 'A Blue Economy for Aotearoa New Zealand?', Environment, Development and Sustainability, Volume 6, Issue 3, June 2014. pp. 459-470.

Bradshaw, Corey J.A, Giam, Xingl i\& Sodhi, Navjot. S, 'Evaluating the Relative Environmental Impact of Countries', PLoS One, 5/5, May 2010.

http://journals.plos.org/plosone/article?id=10.1371/journal. pone.0010440\#pone-0010440-t004. (accessed 07/10/2016).

Campbell, Hugh, 'A Sociology of Agriculture for Crunch Times: Sustainability, Dialogue and the Disciplinary Politics of Knowledge Production in New Zealand Farming', New Zealand Sociology, Vol.24, No.2, 2009. pp. 12-38.

Campbell, Hugh, Burton, Rob, Cooper, Mark, Henry, Matthew, Le Heron, Erena, Le Heron, Richard, Lewis, Nick, Pawson, Eric, Roche, Mike, Rosin, Chris \& White, Toni, 'From agricultural science to “biological economies"?', New Zealand Journal of Agricultural Research, 52, 1, 2009. pp. 91-97. Campbell, Hugh, Rosin, Christopher, Hunt, Leslie \& Fairweather, John, 'The social practice of sustainable agriculture under audit discipline: Initial insights from the ARGOS project in New Zealand', Journal of Rural Studies, 28, 2012. pp. 129-141.

Chein, Mark. L, 'Soil and Site Selection Considerations for Wine Grape Vineyards', College of Agricultural Sciences Cooperative Extension, Penn State University, 2009.

http://www.pawinegrape.com/uploads/PDF\%20files/Documents/Viticulture/Site\%20Selection\%20 for\%20Wine\%20Vineyards_Chein.pdf. (accessed 11/07/2016).

Clark, D.A, Rolston, M.P, Lambert, M.G, Budding, P.J, 'Pasture composition under mixed sheep and goat grazing on hill country', Proceedings of the New Zealand Grasslands Association, 45, 160-166, Palmerston North, 1984.

Cordano, Mark, Marshall, Scott \& Silverman, Murray, 'How Do Small and Medium Enterprises "Green"? A Study of Environmental Management Programs in the U.S Wine Industry', Journal of Business Ethics, Vol.92, No.3, March 2010. pp. 463-478. 
Falloon. J, 'The Wairarapa Region', Journal of New Zealand Grasslands, No.77, Vol.18, 2015. pp. 15-18.

Fountain, Johanna \& Lamb, Charles, 'Generation Y as young wine consumers in New Zealand; How do they differ from Generation X?', International Journal of Wine Business Research, Patrington, 23:4, 2011. pp. 107-124.

-Gabzdylova, Barbara, Raffensprerger, John. F, \& Castka, Pavel, 'Sustainability in the New Zealand Wine Industry: drivers, stakeholders and practices', Journal of Cleaner Production, 2009, Vol.17 (11). pp. 992-998.

Haggerty, Julia, Campbell, Hugh \& Morris, Caroline, 'Keeping the stress of the sheep? Agricultural intensification, neoliberalism and 'good' farming in New Zealand', Geoforum, 40, 2000. pp. 767777.

Holland, Phill, 'The Dirty Dairying Campaign and the Clean Streams Accord', Lincoln Planning Review, 6 (1-2), 2014. pp. 63-69.

Howland, Peter, 'Euro-chic, Benign Cosmopolitanism and Wine Tourism in Martinborough, New Zealand', From Production to Consumption; Transformation of Rural Communities, Horakova, Hana \& Boscoboinik, Andrea (eds), Lit Verlang, Berlin, 2012. pp. 113-129.

Howland, Peter, 'Martinborough's Wine Tourists and the Metro-Rural Idyll', Journal of New Zealand Studies, Issue 6, 2008. pp. 77-100.

Hunt, Lesley. M, Fairweather, John. R, Rosin, Chris. J, Campbell, Hugh, Lucock, Dave \& Greer, Gen, 'Doing the Unthinkable: Linking farmers' breadth of view and adaptive propensity to achievement of social, environmental and economic outcomes', 18th International Farm Management Conference proceedings, New Zealand, 2011.

Keiha, Pare \& Moon, Paul, 'The Emergence and Evolution of Urban Māori Authorities: A Response to Māori Urbanisation', Te Kaharoa, Vol.1, 2008. pp. 1-17.

Macleod, Catriona. J, Moller, Henrik, 'Intensification of New Zealand Agriculture since 1960: An evaluation of current indicators of land use change', Agriculture, Ecosystems and Environment, $115,2006$.

Merchant, Carolyn, 'The Theoretical Structure of Ecological Revolution', Environmental Review: ER, Vol.11, No.4, Special Issue: Theories of Environmental History, winter 1987. p.271. 
Schevdin, C.B, 'Staples and regions of Pax Britannica', The Economic History Review, Vol.43, No.4, November 1990. pp. 533-559.

Schrader, Ben, 'Wairarapa places-Wairarapa lakes', Te Ara- the Encyclopedia of New Zealand. http://www.TeAra.govt.nz/en/wairarapa-places/page-11. (accessed 02/05/2017).

Smith, Willie \& Montgomery, Hayden, 'Revolution or Evolution? New Zealand agriculture since 1984', Geojournal, Vol.59, No.2, Re-inventing Government: Emerging Geographies in New Zealand, 2004. pp. 107-118.

\section{Books}

Bagnall, A. G, Wairarapa; an historical excursion, Hedleys Bookshop LTD for The Masterton Trust Lands Trust, Masterton, 1976.

Bargh, Brian, The struggle for Māori Fishing Rights; Te Ika a Māori, Huia Publishers, Wellington, 2016.

Belich, James, Paradise Reforged; A History of New Zealanders from the 1880s to year 2000, Allen Lane, The Penguin Press, Auckland, 2001.

Bloomfield, C.T, New Zealand: A Handbook of Historical Statistics, G.K. Hall \& Co., Boston, Massachusetts, 1984.

Boast, R, Buying the Land; Governments and Maori land in the North Island 1865-1921, Victoria University Press, Wellington, 2008.

Bollard, Allan \& Buckle, Robert (eds.), Economic Liberalisation in New Zealand, Allen and Unwin, Wellington, 1987.

Bourdieu, Pierre, Practical Reason, On the Theory of Action, Stanford University Press, Stanford, California, 1998.

Brooking, Tom \& Pawson, Eric, Making a new land; environmental histories of New Zealand, University Otago Press, Dunedin, New Zealand, 2013.

Cooper, Michael, The Vines and Vineyards of New Zealand, 4th edition, Hodder and Stoughton, Auckland, 1993.

Cooper, Michael, Wine Atlas of New Zealand, 2nd edition, Hodder Moa, Auckland, 2008.

Cronon, William (ed.), Uncommon Ground; Rethinking the Human Place in Nature, W. W. Norton, New York, 1995. 
Cyclopaedia Company Ltd, The Cyclopaedia of New Zealand; Taranaki, Hawkes Bay and Wellington Provincial Districts, The Cyclopaedia Company Limited, Christchurch, 1908.

Dymond, J.R (ed), Ecosystem Services in New Zealand-Conditions and Trends, Manaaki Whenua Press, Lincoln, New Zealand, 2013.

Easton, Brian, In Stormy Seas; The Post-War New Zealand Economy, Otago University Press, 1997.

Graydon, Jim, On the Edge; Wairarapa's Coastal Communities, Fraser Books, Masterton, 2013.

Gustafson, Barry, His Way; A Biography of Robert Muldoon, Auckland University Press, 2000.

Harvey, David, Justice, Nature, and the Geography of Difference, Blackwell Publishers, Oxford, 1996.

Holland, Peter, Home in the Howling Wilderness; Settlers and the Environment in Southern New Zealand, Auckland University Press, 2013.

Howland, Peter (ed.), Social, Cultural and Economic Impacts of Wine in New Zealand, Taylor and Francis, 16/04/2014.

Hyman, Prue, Women and Economics: A New Zealand Feminist Perspective, Bridget Williams Books, Wellington, 1994.

James, Colin, The Quiet Revolution; Turbulence and Transition in Contemporary New Zealand, Allen and Unwin, Wellington, 1986.

Knight, Katherine, New Zealand Rivers; An Environmental History, Canterbury University Press, 2017.

Le Heron, Richard and Pawson, Eric, Changing Places; New Zealand in the Nineties, Longman Paul, Auckland, 1996.

Matasar, Ann. B, Women of Wine; The Rise of women in the Global Wine Industry, University of California Press, Berkeley, 2006.

McAloon, Jim, Judgements of all kinds; Economic Policy Making in New Zealand 1945-1984, Victoria University Press, Wellington, 2013.

McIntyre, Roberta, Canoes of Kupe; A History of the Martinborough District, Fraser Books, Masterton, 2012.

Park, Geoff, Nga Uruora; ecology and history in a New Zealand landscape, Victoria University Press, Wellington, 1995. 
Selby, Rachel, Moore, Pātaka \& Mulholland, Malcolm(eds), Māori and the Environment; Kaitiaki, Huia Publishers, Wellington, 2010.

Selby, Rachel (ed.), Te Tauihu o Ngā Wānanga; Indigenous voices, Indigenous places, Otaki, 2008.

Staples, Adrienne (ed.), Featherston County New Zealand; visitor guide, 2nd edition, Featherston, 01/5/2006.

Wallace, Neal, When the Farm Gates; The impact of Rogernomics on rural New Zealand, Rachel Scott, Wellington, 2014.

Wheen, R and Hayward, J. (eds.), Treaty of Waitangi Settlements, Bridget Williams Books, Wellington, 2012. 


\section{Statistics}

Climate Data.org, 'Temperature and rainfall Statistics for Dijon, Burgundy', Climate: Burgundy. http://en.climate-data.org/region/312/. (accessed 12/07/2016).

Climate Data.org, 'Temperature and Rainfall Statistics for Martinborough, Wairarapa', Climate: Martinborough,. http://en.climate-data.org/location/32426/. (accessed 12/07/2016).

Climate Data.org, 'Temperature and rainfall Statistics for Wairau Valley', Climate: Wairau Valley. http://en.climate-data.org/location/764990/. (accessed 12/07/2016).

Figure NZ, 'Farm Types in the South Wairarapa District, New Zealand; By Industry Classification, as at June 2012, number of farms', Statistics New Zealand.

http://figure.nz/chart/rlwyvzgecliuvVqY-x2Y9mxKOL7R3ng1D. (accessed 24/04/2017).

ID Community; demographic resources, 'Community Profile: Featherston, Community Profile: Greytown, Community Profile: Martinborough', South Wairarapa District. http://profile.idnz.co.nz/south-wairarapa/about?WebID=10. (accessed 06/04/2017). LIC, Dairy NZ, 'Regional Dairy Statistics, 2002-2004'. http://www.lic.co.nz/pdf/dairy stats 0203 section_3.pdf. (accessed 26/08/2016). LIC, Dairy Statistics 2000/01, Hamilton, 2001. htt[://www.lic.co.nz/pdf/dairy stats/dairy stats2002.pdf. (accessed 25/04/2017). New Zealand Wine, 'Regions: Wairarapa'. http://www.nzwine.com/regions/wairarapa/. (accessed 13/07/2016).

Statistics New Zealand, 'Sheeps and Lambs Tailed by Age, Sex and Territorial Authority as at 30 June 2002', Agricultural Tables 2002, 3 July 2003.

http://www.stats.govet.nz/browse for stats/industry sectors/agriculture-horticultureforestry/2002-agricultural-census-tables/livestock.aspx. (accessed 1/04/2017).

Statistics New Zealand, 'Summary of Livestock by Type and Territorial Authority as at 30 June 2012', Agricultural Tables 2012, 3 July 2013.

http://www.stats.govt.nz/browse for stats/industry sectors/agriculture-horticultureforestry/2012-acricultural-census-tables/livestock.aspx. (accessed 1/04/2017). 
Statistics New Zealand; Infoshare, 'Variable by Territorial Local Authority (Annual-Jun); South Wairarapa District'. http://www.stats.govt.nz/infoshare/ViewTable.aspx?pxID=aca2a10b-486f4bee-9d3d-f40f90d76ffe. (accessed 20/4/2017).

Statistics New Zealand, '1999 Agricultural Production: national and regional changes', Key Statistics, August 2000. http://www.stats.govt.nz/browse for stats/industry sectors/agriculturehorticulture-forestry/1999-agricultural-production-national-regional-changes.aspx. (accessed 20/04/2017).

Statistics New Zealand, 'Wairarapa agricultural areas in hectares, by usage at 30 June 2007', Agricultural Census, 2007.

http://www.stats.govt.nz/browse for stats/industry sectors/agriculture-horticultureforestry/2007-agricultural-census-tables/land-use-farm-counts.aspx. (accessed 20/03/2017).

Statistics New Zealand, 'Deer numbers in New Zealand as at June 30, from 1971'.

http://maxa.maf.govt.nz/statistics/pastoral/livestock-numbers/. (accessed 28/09/2016).

Statistics New Zealand, 'Beef Cattle numbers as at June 30, from 1971'.

http://maxa.maf.govt.nz/statistics/pastoral/livestock-numbers/. (accessed 28/09/2016).

Statistics New Zealand, 'Quick Stats about the South Wairarapa District', Census 2013.

http://www.stats.govt.nz/Census/2013-census/profile-and-summary-reports/quickstats-about-aplace.aspx?request_value=14536\&tabname+\&sc device=pdf. (accessed 24/06/2016). 


\section{Images}

Alexander Turnbull Library, 'Māori group on the Ruamāhanga River, Wairarapa, (1870s-1880s), Reference Number: 1/2-107060.

http://mp.natlib.govt.nz/detail/?id=8252\&l=mi. (accessed 07/02/2017).

Durie, Mason \& Durie, Meihana, 'Rangitāne-20th and 21st centuries: survival and adaptation', Te Ara - the Encyclopaedia of New Zealand, http://www.TeAra.govt.nz/en/map/1500/map-ofrangitane-marae. (accessed 27/02/2017).

Ngāti Kahungunu Iwi Inc., 'Our Marae'. http://www.kahungunu.iwi.nz/our-marae. (accessed 27/02/2017).

South Wairarapa District Council, 'Wairarapa Maps', District Plan.

http://mapping.gw.govt.nz/Wairarapa/. (accessed 04/05/2017).

The Wairarapa Archives, 'map of Wairarapa Moana', 1855.

http://www.wairarapamoana.org.nz/page75848.html. (accessed 01/02/2017).

\section{Online Resources}

Martinborough.com, 'Home page', http://www.martinborough.com. (accessed 09/05/2017).

New Zealand Wine, 'Wairarapa Wine NZ; Explore all Wineries',

http://ww.nzwine.com/regions/wairarapa/\#explore-wineries. (accessed 24/05/2016).

New Zealand Wine, 'What does "sustainable" mean for NZ wine?'.

http://www.nzwine.com/sustainability/about/what-does-sustainable-mean-for-nz-wine-1/. (accessed 14/07/2016).

Te Whanake; Māori Dictionary online. http://maoridictionary.co.nz/.

Toast Martinborough Wellington, 'All about Toast', http://toastmartinborough.co.nz/your-firstfestival/. (accessed 20/04/2017). 
